\title{
Chalcones as Versatile Synthons for the Synthesis of 5- and 6-membered Nitrogen Heterocycles
}

\author{
Hélio M.T. Albuquerque ${ }^{\mathrm{a}}$, Clementina M.M. Santos ${ }^{\mathrm{a}, \mathrm{b}}$, José A.S. Cavaleiro ${ }^{\mathrm{a}}$ and \\ Artur M.S. Silva ${ }^{\mathrm{a}, *}, \#$
}

${ }^{a}$ Department of Chemistry \& QOPNA, University of Aveiro, Campus de Santiago, 3810-193 Aveiro, Portugal; ${ }^{b}$ Department of Vegetal Production and Technology, School of Agriculture, Polytechnic Institute of Bragança, 5301855 Bragança, Portugal

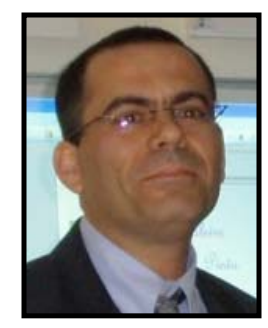

\begin{abstract}
Chalcones belong to the flavonoid family which constitutes one of the major classes of naturally occurring oxygen heterocyclic compounds. The $\alpha, \beta$-unsaturated carbonyl system of chalcones possesses two electrophilic reactive centers allowing them to participate in addition reactions via attack to the carbonyl group (1,2-addition) or involving the $\beta$-carbon (1,4-conjugate addition), leading to the synthesis of promising bioactive heterocyclic compounds. The purpose of this review is to present a systematic survey of the most recent literature that uses chalcones in the synthesis of biologically active 5- and 6-membered nitrogen heterocycles such as pyrroles, indoles, isoxazoles, imidazoles, pyrazoles, indazoles, triazoles, tetrazoles, pyridines and pyrimidines. Efficiency, easy-to-handle and cheap reagents, alternative heating conditions and greener protocols will be highlighted. In this review we will cover the literature since the beginning of the $21^{\text {st }}$ century in more than 400 publications.
\end{abstract}

Keywords: Chalcones, cycloaddition reactions, Michael addition, nitrogen heterocyclic compounds, reactivity, synthetic methods.

\#Author's Biography: Artur M. S. Silva studied chemistry at the University of Aveiro (Portugal) where he graduated in chemistry physics in 1987. In 1993 he received his $\mathrm{PhD}$ in chemistry at Aveiro University. He began his independent career at Aveiro University as an Assistant Professor in 1994. He was appointed to Associate Professor with tenure in 1998 and Full Professor in 2001. Professor Artur Silva has published over 430 papers 17 book chapters. He supervised more than $15 \mathrm{PhD}$ and $25 \mathrm{MSc}$ students and several post-doctoral fellows. His research interests range over the chemistry of polyphenolic and nitrogen heterocyclic compounds, with special emphasis on the development of new synthetic routes, and also on the organocatalytic transformations. However, the second passion of his research is centred in the isolation and structural characterization of natural products from diverse terrestrial and marine sources.

\section{INTRODUCTION}

1,3-Diaryl-2-propen-1-ones commonly named as chalcones are naturally occurring $\alpha, \beta$-unsaturated ketones with two aromatic rings (A and $\mathrm{B}$ ) belonging to the flavonoid family [1]. The numbering system is different from that presented by other flavonoids, being the A-ring numbered from 1' to 6' and the B-ring from 1 to 6 (Fig. 1). Chalcones are widely spread in nature (fruits, vegetables, spices, tea and soy based foodstuff) and their 2'-hydroxy derivatives play an important role in the flavonoid synthesis and biosynthesis as both precursors and products [1].
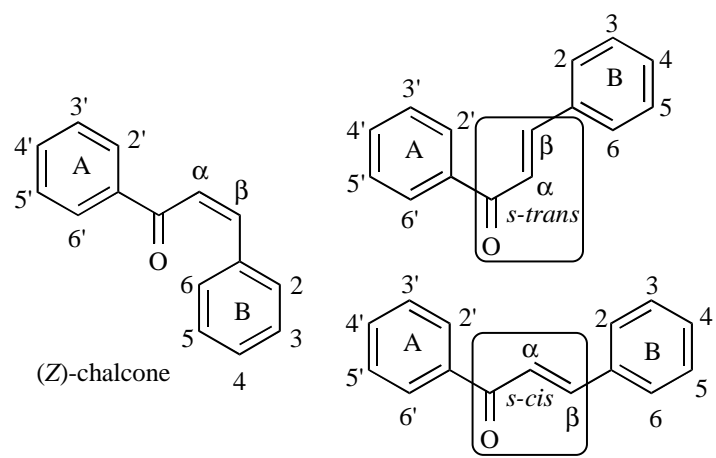

(E)-chalcone

Fig. (1). General structure of chalcones 1.

*Address correspondence to this author at the Department of Chemistry \& QOPNA, University of Aveiro, Campus Universitário de Santiago, 3810-193 Aveiro, Portugal; Tel: +351 234 370714; Fax: +351234 370084; E-mail: artur.silva@ua.pt
Chalcones are the subject of continuous experimental and theoretical investigations. These flexible molecules appear in various conformations, and their properties depend on a suitable ring substitution as well as on the presence of the $\alpha, \beta$-unsaturated ketone moiety. The $\mathrm{C} \alpha=\mathrm{C} \beta$ double bond can exist either in the $(E)$ - or $(Z)$ configuration (Fig. 1), being the $(E)$-form the thermodynamically most stable and consequently, the majority of the chalcones isisolated as the $(E)$-isomer [2]. The $s$-cis conformation for the $\mathrm{O}=\mathrm{C}$ $\mathrm{C} \alpha=\mathrm{C} \beta$ system is adopted by the most stable conformer [3] (Fig. 1). In addition, planar [3] and non-planar [4] structures have been reported for the most stable conformers using different computational levels.

The parent $(E)$-chalcone was not found as a natural product but some simple derivatives such as 4'-hydroxy- and 4'-methoxychalcones have been found in plants of the genus Citrus and Flemingia, respectively. Natural derivatives can present substituents in both aromatic rings being the hydroxyl, methoxyl, methyl and isopentenyl the most frequent ones. These compounds can also be isolated in the free form or as $O$ - or $C$-glycosides, with glucose and rhamnose as the predominant sugar residues [5].

In nature, $(E)$-chalcones have shown to display an important role in pigmentation of flowers and can act as protecting agents against microorganisms, insects and ultraviolet radiation. They can also present other biological, pharmacological and biocidal properties, such as antibacterial [6], anti-inflammatory [7-9], antifungal [6], antimalarial [10-12], antitumor [13], antimicrobial [14, 15], antiviral [16], antitubercular [17], antioxidant [18], antimitotic [19], antileishmanial [20], antiplatelet [21], anticancer [22] activities, among others [23, 24]. 
The referred biological properties are closely related to important structural features of chalcones, however there is only a small number of studies on the structure-activity relationship. For instance, it has been shown that a $\mathrm{C} \alpha=\mathrm{C} \beta$ double bond is essential for a high antimalarial activity, while substitution in this double bond causes a significant decrease in the inhibitory activity. The presence of chloro, fluoro or small, lipophilic nitrogen heterocycles as substituents on the A ring and electron-donating substitution or small hydrophobic functionality on the $\mathrm{B}$ ring increases the antimalarial activity $[25,26]$. A QSAR study has shown that hydrophobic and steric properties seem to play an important role in the explanation of the antimalarial activity (inhibitory activity of $P$. falciparum cysteine protease) of chalcones [27], although other authors recommended simultaneous substitutions in both $\mathrm{A}$ and $\mathrm{B}$ rings which weaken specific bonds of the chalcone structure [28]. There are other few studies on the structure-biological activity of chalcones, namely on antibacterial [29] and antitumor [30, 31] activities.

The simple skeleton of chalcones, its diversified biological activities, and also the small amounts obtained by isolation from natural sources, still prepare the synthesis of chalcones and chalconetype functionalized derivatives an important and challenging topic. In fact, several academic and industrial chemists dedicate their efforts to the search of alternative and more efficient routes for the synthesis of this type of compounds and even novel derivatives with improved biological applications. Recent literature provides a series of procedures for the synthesis of chalcones; among them Aldol condensation and cross-Aldol condensation known as Claisen-Schmidt condensation are the most often used. The Claisen-Schmidt condensation involves the reaction of acetophenones with benzaldehydes and the resulting chalcones include Aring substituents supplied by the acetophenone $\left(R^{1}\right)$ and B-ring substituents given by the benzaldehyde $\left(\mathrm{R}^{2}\right)$ (Scheme $\left.\mathbf{1}\right)$ [32].

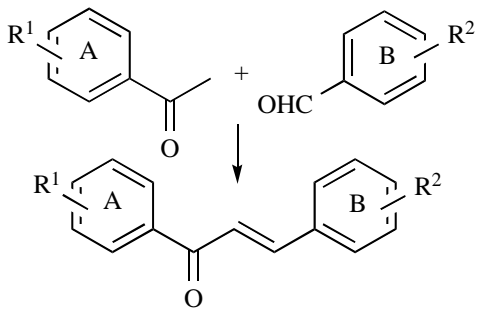

Scheme 1. Synthesis of chalcones by a Claisen-Schmidt condensation.

The traditional Claisen-Schmidt reaction is usually carried out in aqueous $\mathrm{NaOH}$ or $\mathrm{KOH}$ or in ethanolic sodium ethoxide at room temperature for several hours. The Claisen-Schmidt condensation can also be performed in the presence of other bases $\left[\right.$ e.g. $\mathrm{Ba}(\mathrm{OH})_{2}$, $\mathrm{LiOH}$, anhydrous $\mathrm{K}_{2} \mathrm{CO}_{3}$ ] and even in acidic conditions $(\mathrm{HCl}$, $\mathrm{BF}_{3} \bullet \mathrm{OEt}_{2}, \mathrm{~B}_{2} \mathrm{O}_{3}, p$-toluenesulfonic acid). This reaction can also be performed by using solid-phase catalysts, heterogeneous catalysis, acidic ionic liquids, zeolites, iodine, among other catalysts. Some improved strategies include solvent-free conditions, microwave and ultrasound irradiation and the grinding technique [33].

Chalcones can also be synthesized by palladium-catalyzed cross-coupling reactions. Under microwave heating, direct crosscoupling reaction of benzoyl chlorides and potassium styryltrifluoroborates using $\mathrm{PdCl}_{2}\left(\mathrm{~d}^{t} \mathrm{bpf}\right)$ as catalyst provides a series of chalcones [34]. Other derivatives are obtained by a Suzuki crosscoupling reaction of benzoyl chlorides with arylvinylboronic acids mediated by $\mathrm{Pd}\left(\mathrm{PPh}_{3}\right)_{4}$ and using cesium carbonate as base [35]. Other approaches for the synthesis of chalcones include the Friedel-Crafts reaction of phenols with cinammoyl chloride [5] and the use of heteroarylsulfonylarylethanones as coupling reagents in the Julia-Kocienski olefination of benzaldehydes in the presence of DBU in THF [36].

Among all the described synthetic routes the base-catalyzed Claisen-Schmidt reaction is the method of primary choice for the synthesis of chalcones, because of the accessibility of the preliminary materials such as acetophenones and benzaldehydes. In the acidic conditions, the method using $\mathrm{BF}_{3} \bullet \mathrm{OEt}_{2}$ has particular relevance due to high yields, simple work-up, short reaction times and no side reactions. This method is used in solvent free reactions and is appropriate for reactions concerning liquid reactants possessing base sensitive functional groups $e . g$. esters and amides.

Compounds with an $\alpha, \beta$-unsaturated carbonyl system (as chalcones) possess two electrophilic reactive centers, due to delocalization of electron density in the $\mathrm{C}=\mathrm{C}-\mathrm{C}=\mathrm{O}$ system, allowing them to participate in addition reactions via attack to the carbonyl group (1,2-addition) or involving the $\beta$-carbon (1,4-conjugate addition), leading to the synthesis of promising bioactive heterocyclic compounds. The purpose of this review is to present a systematic survey of the most recent literature that uses chalcones in the synthesis of biologically active 5- and 6-membered nitrogen heterocycles such as pyrroles, indoles, isoxazoles, imidazoles, pyrazoles, indazoles, triazoles, tetrazoles, pyridines and pyrimidines.

The reactivity of $\alpha, \beta$-unsaturated carbonyl compounds devoted to the synthesis of 5- and 6-membered azaheterocycles was the subject of a book published in 1998 [37] and another in 2008 [38]. Although the most recent chapter describes the most important aspects of pyrazoles, isoxazoles, pyridines and pyrimidines up to 2007 , we will cover the literature from the $21^{\text {st }}$ century trying to have a coherent and complete review in the transformation of chalcones to 5- and 6-membered heterocyclic compounds, in more than 400 publications. Efficiency, easy-to-handle and economic reagents, alternative heating conditions and greener protocols will be highlighted.

\section{TRANSFORMARTION OF CHALCONES}

\subsection{5-Membered Nitrogen Heterocycles}

\subsubsection{Transformation of Chalcones to Pyrroles}

The pyrrole moiety is an important part of many natural products [39]. Highly substituted pyrrole derivatives have been extremely attended, because they are the structural units in many pharmacologically active compounds, such as porphyrins (e.g. heme and chlorophylls) [40], and some pyrrole-based alkaloids (e.g. hygrine, nicotine, tropine, and cocaine) [41].

Several synthetic pyrrole derivatives have shown to possess interesting biological and/or biomedical properties. For example, the 3-(4-pyridyl)-2-(4-fluorophenyl)-5-(4-methylsulfinylphenyl)- $1 \mathrm{H}$ pyrrole was reported to be a potent, orally bioactive inhibitor of $\mathrm{p} 38$ mitogen-activated protein (MAP) kinase [42], which was found to be implicated in Alzheimer's disease [43, 44], cancer [45, 46], asthma [47] and cardiovascular diseases [48]. Also, other pyrrole derivatives such as 1,2-diaryl-1H-pyrroles $[49,50]$ and 2,3-diaryl$1 \mathrm{H}$-pyrroles $[51,52]$ were identified as cyclooxygenase-2 (COX-2)selective inhibitors [53, 54]. Some 5-hydroxy-1,5-dihydro- $2 \mathrm{H}$ pyrrol-2-ones have been shown to be useful in the treatment of patients suffering from intellectual or nervous asthenias, memory failures, senescence or mental strain [55].

The cycloaddition reaction of chalcones with isocyanides seems to be a straightforward route towards the synthesis of pyrroles or pyrrolones. It appears that the reaction of isocyanides with 3- 
benzylidenepenta-2,4-dione was a convenient route for the preparation of substituted 2-aminofurans [56]. However, it was later proved that 2-aminofurans were only the intermediates of this reaction and 5 -hydroxy-2 $H$-pyrrol-2-ones were the products of the $[1+4]$ cycloaddition reaction of alkyl isocyanides with highly electrondeficient benzylidene-1,3-diketones [57]. Thus, Adib et al. reported in 2007 the reaction of isocyanides with less-electrophilic chalcones under solvent-free conditions for the formation of substituted 5hydroxy-2H-pyrrol-2-ones, in excellent yields (Scheme 2) [58].

2-Isocyanoacetates can also be used in the DBU-promoted cascade reaction with $(E)$-2-alkynylchalcones to afford tetrahydroindeno[2,1- $b]$ pyrroles. The reaction occurs in an air atmosphere, under mild conditions and without loss of efficiency for a wide range of substituents (Scheme 3) [59].

$$
\begin{aligned}
& \text { (i) solvent-free, } 150{ }^{\circ} \mathrm{C}, 30 \mathrm{~min} \\
& \mathrm{R}=\text { alkyl } \\
& \mathrm{Ar}^{1}=\mathrm{Ph}, 4-\mathrm{MeOC}_{6} \mathrm{H}_{4} \\
& \mathrm{Ar}^{2}=\mathrm{Ph}, \mathrm{ClC}_{6} \mathrm{H}_{4}, \mathrm{FC}_{6} \mathrm{H}_{4}, \mathrm{MeC}_{6} \mathrm{H}_{4}, \mathrm{MeOC}_{6} \mathrm{H}_{4}
\end{aligned}
$$

Scheme 2. Solvent-free synthesis of 5-hydroxy-2H-pyrrol-2-ones.

$$
\begin{aligned}
& \mathrm{R}^{1}=\mathrm{H}, 5-\mathrm{F}, 5-\mathrm{Me}^{4}, 4,5-\left(\mathrm{OMe}_{2}\right. \\
& \mathrm{R}^{2}={ }^{n} \mathrm{Bu}, \mathrm{Ph}_{4}, \mathrm{MeC}_{6} \mathrm{H}_{4}, 4-\mathrm{MeOC}_{6} \mathrm{H}_{4} \\
& \mathrm{R}^{3}={ }_{\mathrm{Bu}, \mathrm{Me}} \\
& \mathrm{Ar}=\mathrm{Ph}, 4-\mathrm{BrC} \mathrm{H}_{4}, 4-\mathrm{ClC}_{6} \mathrm{H}_{4}, 4-\mathrm{MeC}_{6} \mathrm{H}_{4}, 4-\mathrm{MeOC}_{6} \mathrm{H}_{4}
\end{aligned}
$$

Scheme 3. DBU-mediated cascade reaction of $(E)$-2-alkynylchalcones with 2-isocyanoacetates.

Regioselective synthesis of polysubstituted pyrroles occurred through the reaction of $\alpha$-azidochalcones with 1,3-dicarbonyl compounds. This microwave assisted reaction is promoted by indium trichloride in water and provides substituted pyrroles in $71-94 \%$ yield [60].

In the past few years, multicomponent intermolecular 1,3dipolar cycloaddition reactions have earned a great interest due to their synthetic efficiency, intrinsic atom economy and simple experimental procedures [61-63]. Therefore, the 1,3-dipolar cycloaddition reaction of ninhydrin, L-proline and chalcones provided spiroindane-1,3-dione pyrrolizidines in good yields and with high regio- and stereoselectivity (Scheme 4) [64]. Chalcone dendrimers undergo 1,3-dipolar cycloaddition reaction with sarcosine and an excess of paraformaldehyde in refluxing toluene to prepare $\mathrm{N}$ methylpyrrolidine dendrimers [65].

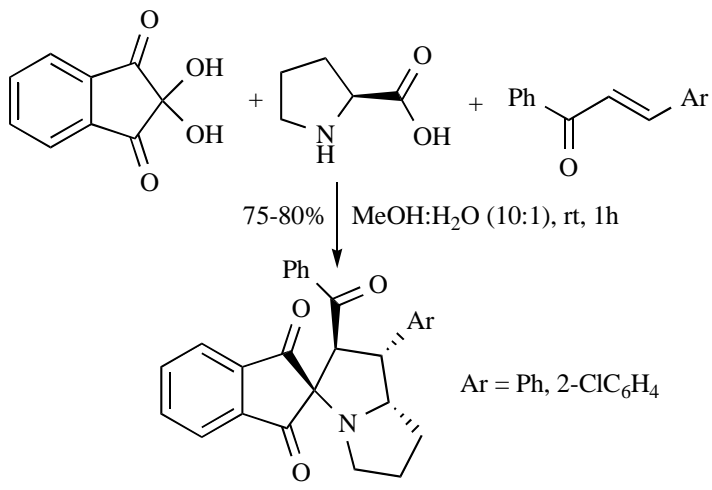

Scheme 4. 1,3-Dipolar cycloaddition reaction of ninhydrin, L-proline and chalcones.

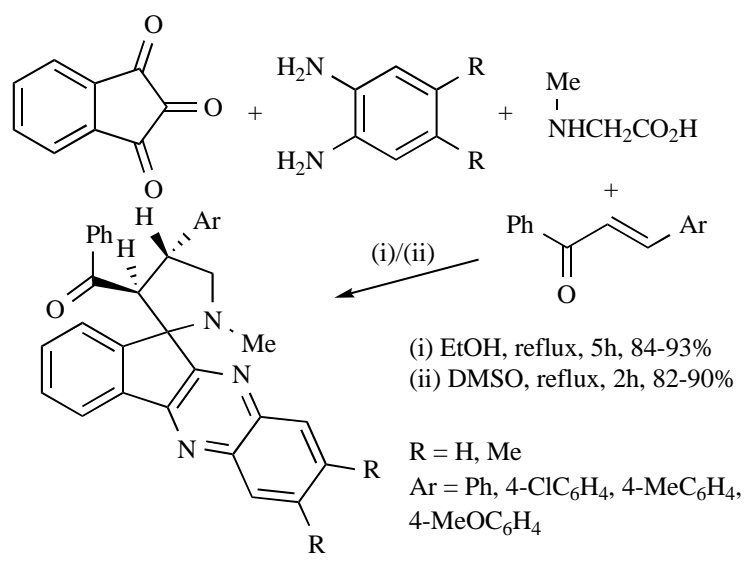

Scheme 5. Four-component 1,3-dipolar cycloaddition reaction of ninhydrin, arylenediamines, sarcosine and chalcones.

Moemeni et al. used a one-pot four-component 1,3-dipolar cycloaddition reaction of ninhydrin, arylenediamines, sarcosine and chalcones to prepare highly substituted pyrrolidines in good yields and stereoselectivity (Scheme 5) [66].

A range of polysubstituted 3,5-diaryl-4,5-dihydropyrroles can be achieved in a one-pot protocol through a Michael addition of nitroalkanes to chalcones and subsequent reductive cyclization in aqueous media [67]. The reaction of chalcones with 2(aminomethyl)benzimidazole gave access to trans-3,5-diaryl-2benzimidazol-2-yl-4,5-dihydropyrroles in moderate to good yields (Scheme 6) [68]. Reduction of some derivatives with sodium borohydride in methanol led to the corresponding pyrrolidines.

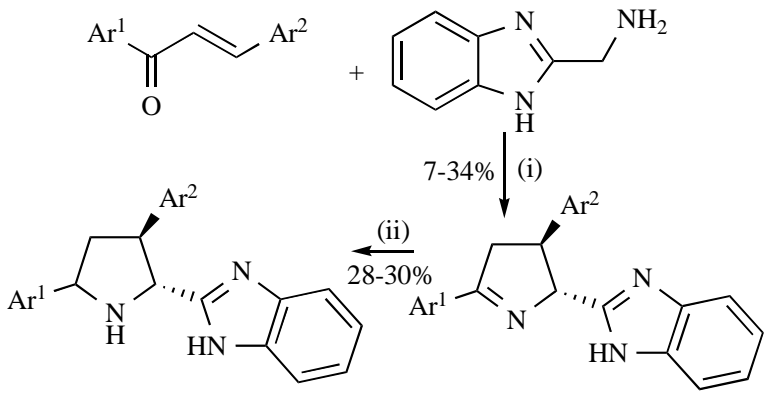

(i) DMF, reflux, $2 \mathrm{~h}$

(ii) $\mathrm{NaBH}_{4}, \mathrm{MeOH}, \mathrm{rt}, 1.5 \mathrm{~h}$

$\mathrm{Ar}^{1}=\mathrm{Ph}, 4-\mathrm{ClC}_{6} \mathrm{H}_{4}, 4-\mathrm{IC}_{6} \mathrm{H}_{4}, 4-\mathrm{MeC}_{6} \mathrm{H}_{4}$

$\mathrm{Ar}^{2}=\mathrm{Ph}, 2-\mathrm{ClC}_{6} \mathrm{H}_{4}, 4-\mathrm{ClC}_{6} \mathrm{H}_{4}, 4-\mathrm{FC}_{6} \mathrm{H}_{4}, 4-\mathrm{MeC}_{6} \mathrm{H}_{4}$

Scheme 6. Reaction of 2-(aminomethyl)benzimidazol with chalcones. 
9H-Pyrrolo[1,2- $a$ ]indoles was achieved through the one-pot reaction of 3-substituted-4,6-dimethoxyindoles with chalcones in the presence of hydrochloric acid (Scheme 7) [69].

\subsubsection{Transformation of Chalcones to Indoles}

The indole heterocyclic system is an important scaffold in medicinal chemistry since it is incorporated into proteins in the tryptophan residue, is the basis of drugs like indomethacin and also because it provides the skeleton of indole alkaloids. The indole nucleus possesses a wide range of biological activities being a biologically accepted pharmacophore in medicinal compounds. Antiinflammatory [70], antifungal [71], antimicrobial [72], anticancer [73, 74], anti-HIV [75], antioxidant [76], and antiviral [77] activities, among many others, are some examples of the biological potential of indole derivatives.

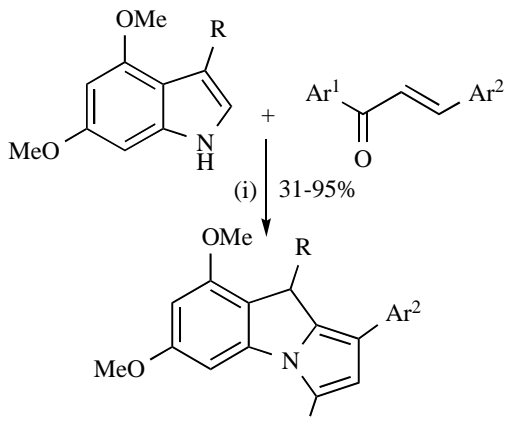

(i) $\mathrm{HCl},{ }^{i} \mathrm{PrOH}$, reflux, $3 \mathrm{~h}^{\mathrm{Ar}^{1}}$

$\mathrm{R}=\mathrm{Me}, \mathrm{Ph}, 4-\mathrm{ClC}_{6} \mathrm{H}_{4}, 4-\mathrm{MeOC}_{6} \mathrm{H}_{4}$

$\mathrm{Ar}^{1}=\mathrm{Ph}, 4-\mathrm{ClC}_{6} \mathrm{H}_{4}, 4-\mathrm{MeC}_{6} \mathrm{H}_{4}, 4-\mathrm{MeOC}_{6} \mathrm{H}_{4}$

$\mathrm{Ar}^{2}=\mathrm{Ph}, 4-\mathrm{ClC}_{6} \mathrm{H}_{4}, 4-\mathrm{MeOC}_{6} \mathrm{H}_{4}$

Scheme 7. Synthesis of $9 H$-pyrrolo[1,2-a]indoles.

There was only one report concerning the synthesis of indoletype compounds using chalcones as starting materials. In this report, 2-aryl-1-benzoylindolizine derivatives were prepared in moderate yields through $\mathrm{CrO}_{3} / \mathrm{Et}_{3} \mathrm{~N}$-promoted 1,3-dipolar cycloaddition reaction of $N$-pyridinium bromides 1 with chalcones (Scheme 8) [78]. The use of $N$-isoquinolinium bromides 2 instead of $N$ pyridinium derivatives $\mathbf{1}$ afforded the corresponding 2-aryl-1benzoylpyrrolo[2,1-a]isoquinolines (Scheme 8) [78].

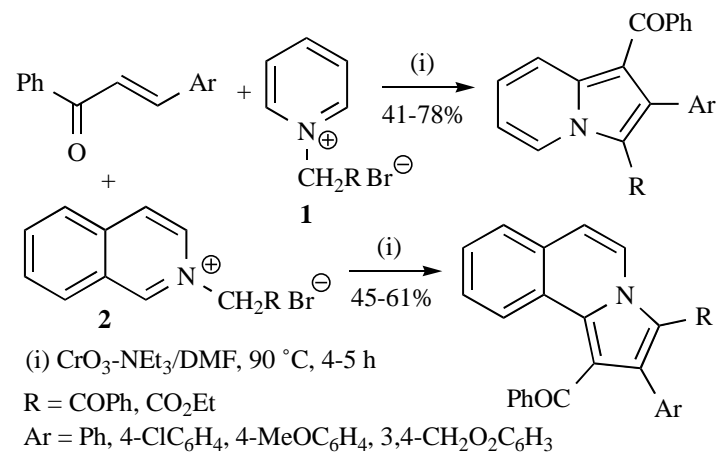

Scheme 8. $\mathrm{CrO}_{3} / \mathrm{NEt}_{3}$-promoted 1,3-dipolar cycloaddition of pyridinium $\mathrm{N}$ ylides $\mathbf{1}$ and isoquinolinium $N$-ylides $\mathbf{2}$ with chalcones.

\subsubsection{Transformation of Chalcones to Isoxazoles}

As the majority of azaheterocycles, isoxazoles are associated to an extensive range of biological activities. Amongst them we can find antiviral [79], antihelmintic [80], anti-inflammatory [81], anticonvulsant [82], and anticancer activities [83]. Several reports also showed that substituted isoxazoles, e.g. isouron, isoxaben and isoxathion are effective and degradable pesticides [84].
3,5-Diarylisoxazoles can be prepared through the reaction of chalcones with hydroxylamines. The formation mechanism of the isoxazole moiety involves the formation of oxime intermediates while hydrazones are formed in the case of pyrazoles. Several authors used this reaction successfully in refluxing ethanol and using $\mathrm{NaOH}$ [85] or $\mathrm{KOH}$ [86-91] as base. The reaction of chalcones with hydroxylamine hydrochloride can also be performed in the presence of NaOAc and glacial acetic acid to give 3,5diarylisoxazoles $[92,93]$. Using the same conditions, the condensation of benzimidazolyl-, benzofuranyl-, indolyl- and quinoxalinyltype chalcones with hydroxylamine hydrochloride provided, respectively, benzimidazolyl- [94], benzofuranyl- [95], indolyl- [96] and quinoxalinyl-isoxazoles [97].

3,5-Diarylisoxazoles were also obtained in excellent yields from chalcone oximes under solvent-free conditions [98].

A few 3,4,5-trisubstituted isoxazoles were accomplished when $\alpha, \beta$-disubstituted chalcones reacted with hydroxylamine hydrochloride in ethanol at $65-80{ }^{\circ} \mathrm{C}$ [99].

High yields of methylenebis-isoxazoles arise from the condensation of methylenebischalcones with hydroxylamine hydrochloride and $\mathrm{NaOAc}$ in refluxing ethanol [100].

4,5-Disubstituted isoxazoles can also be obtained in a two-step synthesis starting from the tosylation of chalcones to give the corresponding $\alpha, \beta$-ditosylate derivatives and subsequent reaction with hydroxylamine to afford the desired isoxazoles (Scheme 9) [101]. A similar approach involves the reaction of $\alpha, \beta$-dibromo-chalcones with hydroxylamine hydrochloride in ethanol and using $\mathrm{KOH}$ as base [102-104].

$$
\begin{aligned}
& \text { (i) } \mathrm{HTIB}_{2} \mathrm{CH}_{2} \mathrm{Cl}_{2}, 40{ }^{\circ} \mathrm{C}, 16-18 \mathrm{~h} \\
& \text { (ii) } \mathrm{NH}_{2} \mathrm{OH} \mathrm{HCl}, \mathrm{NaOAc}, \mathrm{EtOH}, \text { reflux, } 3 \mathrm{~h} \\
& \mathrm{HTIB}=\mathrm{hydroxy}(\text { tosyloxy)iodobenzene } \\
& \mathrm{Ar}^{1}=\mathrm{Ph}, 4-\mathrm{BrC}_{6} \mathrm{H}_{4}, 4-\mathrm{ClC}_{6} \mathrm{H}_{4}, 4-\mathrm{MeC}_{6} \mathrm{H}_{4}, 4-\mathrm{MeOC}_{6} \mathrm{H}_{4} \\
& \mathrm{Ar}^{2}=\mathrm{Ph}, 4-\mathrm{ClC}_{6} \mathrm{H}_{4}, 4-\mathrm{MeC}_{6} \mathrm{H}_{4}, 4-\mathrm{MeOC}_{6} \mathrm{H}_{4}, 2 \text {-thienyl, } \\
& \text { 5-methyl-2-thienyl }
\end{aligned}
$$

Scheme 9. Synthesis of 4,5-disubstituted isoxazoles from $\alpha, \beta$-ditosylate chalcones.

An iodine-mediated tandem reaction of 2-alkynylchalcones with hydroxylamine hydrochoride gave naphtho[2,1-d]isoxazoles (Scheme 10). This one-pot reaction involves an oxidative cyclocondensation followed by an electrophilic hydroarylation [105].

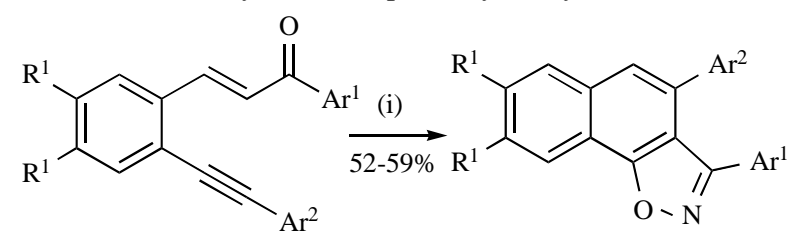

(i) $\mathrm{NH}_{2} \mathrm{OH} \cdot \mathrm{HCl}, \mathrm{I}_{2}, \mathrm{AcOH}$, reflux, $8 \mathrm{~h}$

$$
\begin{aligned}
& \mathrm{R}^{1}=\mathrm{H}, \mathrm{MeO} \\
& \mathrm{Ar}^{1}=\mathrm{Ph}, 4-\mathrm{BrC}_{6} \mathrm{H}_{4}, 4-\mathrm{MeOC}_{6} \mathrm{H}_{4} \\
& \mathrm{Ar}^{2}=\mathrm{Ph}, 4-\mathrm{MeOC}_{6} \mathrm{H}_{4}
\end{aligned}
$$

Scheme 10. Iodine-promoted tandem oxidative cyclocondensation of 2alkynylchalcones with hydroxylamine hydrochloride. 
Instead of 3,5-diarylisoxazoles, a series of 3,5-diaryl-2isoxazoline derivatives is attained from the reaction of chalcones with hydroxylamine hydrochloride with minor modifications in an appropriate solvent (usually a protic solvent such as ethanol and methanol) and using a catalytic amount of a base such as $\mathrm{KOH}$ [102, 106-109], $\mathrm{NaOH}$ [102-115] and NaOAc [116-119]. Replacing the solvent by acetic acid, a series of 2-isoxazolines arises from the reaction of hydroxylamine hydrochloride in the presence of $\mathrm{NaOAc}$ with chalcone-based compounds bearing pyrrole [120], methylenebisthiazolidinone [121] and benzimidazole [122] moieties. Other modifications involve the use of pyridine [123-125] or triethanolamine [126] that act as both solvent and base. Refluxing bischalcones with hydroxylamine hydrochloride in pyridine afforded bisisoxazolines in high yields [127]. Few examples of 3,5-diaryl-2isoxazolines were obtained when chloro-substituted chalcones reacts with hydroxylamine hydrochloride in refluxing DMF containing piperidine [128]. An ecofriendly reaction occurs efficiently in the presence of the ionic liquid butylmethylimidazolium bromide $\{[\mathrm{bmim}] \mathrm{Br}\}$, acting as solvent and catalyst (Scheme 11) [123].

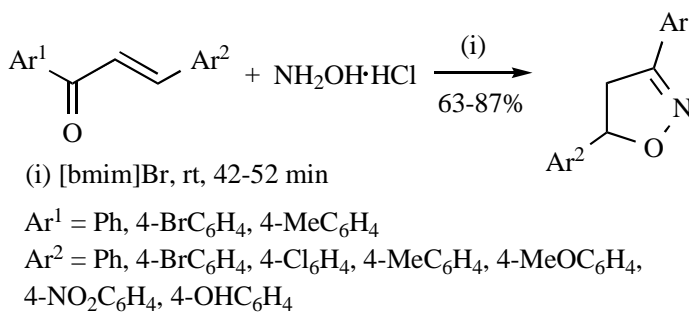

Scheme 11. Synthesis of 3,5-diaryl-2-isoxazolines mediated by the ionic liquid [bmim]Br.

Varying the conditions, cyclocondensation of hydroxylamine hydrochloride with other chalcone-type compounds with different scaffolds such as benzo[b][1,4]diazepine [129], naphtho[2,1b]furan [130], pyrazole [131], pyrazoline [132], indole [133-135], quinazoline [82, 136], triazinylaminophenyl [137] and benzimidazole under microwave irradiation [138] give access to several functionalized 2-isoxazolines.

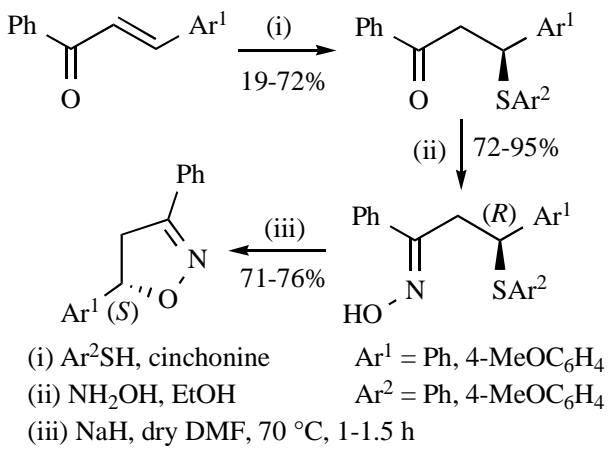

Scheme 12. Stereospecific synthesis of chiral isoxazolines from oximes of chiral Michael adducts of thiophenols to chalcones.

Several antimicrobial nitrogen heterocycles bearing an isoxazole moiety or substituted isoxazole derivatives were also obtained from the condensation of the appropriate chalcones with hydroxylamine hydrochloride [139-143].

The stereospecific synthesis of chiral isoxazolines from oximes of chiral Michael adducts of thiophenols to chalcones was reported in 2005 by Zielinska-Błajet et al. [144]. The key step of this synthesis is the ring-closure reaction, which occurs by a stereospecific intramolecular $\mathrm{S}_{\mathrm{N}} 2$-type reaction with thiophenoxide as a leaving group. The desired isoxazolines were obtained in good yields and dextrorotatory level $(57-86 \% e e)$ which after recrystallization achieved a high enantiomeric excess (> 98\% ee) (Scheme 12).

1,3-Dipolar cycloaddition reaction of 1,2,4-triazol-substituted chalcones with a variety of benzaldoximes in the presence of chloramine- $T$ gave access to the corresponding isoxazolines in moderate yields (Scheme 13) [145].

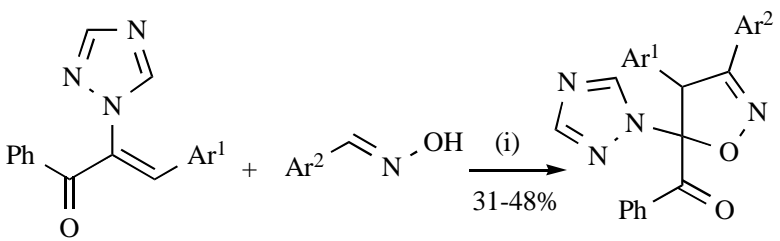

(i) chloramine- $\mathrm{T}, \mathrm{MeOH}$, reflux, $7 \mathrm{~h}$

$\mathrm{Ar}^{1}=\mathrm{Ph}, 4-\mathrm{ClC}_{6} \mathrm{H}_{4}, 4-\mathrm{MeC}_{6} \mathrm{H}_{4}, 4-\mathrm{MeOC}_{6} \mathrm{H}_{4}$ $\mathrm{Ar}^{2}=\mathrm{Ph}, 4-\mathrm{ClC}_{6} \mathrm{H}_{4}, 4-\mathrm{MeC}_{6} \mathrm{H}_{4}$

Scheme 13. Synthesis of 1,2,4-triazole-substituted 2-isoxazolines.

A liquid-phase synthesis of 3,4,5-trisubstituted isoxazolines using poly(ethyleneglycol) (PEG) as support was reported in 2008 [146]. This methodology involves the 1,3-dipolar cycloaddition reaction of the in situ generated soluble-polymer-supported nitrile oxide with chalcones to afford the polymer-supported isoxazolines, which after cleavage with sodium methoxide provided the substituted isoxazoles (Scheme 14).

Some improvements in yields and reaction time were achieved through microwave assisted synthesis. 2-Isoxazolines were obtained with only a few minutes of irradiation in the reaction of chalcones with hydroxylamine hydrochloride [147-152]. Kidwai et al. used $\mathrm{K}_{2} \mathrm{CO}_{3}$ as solid support in the cyclization of the Michael adducts from the reaction of hydroxylamine with chalcones [153]. Similar reactions are carried out in the presence of basic alumina as solid support and under microwave irradiation [124, 154].

Not only hydroxylamines are used to synthesize isoxazoles. An unusual nitrone ( $N$-hydroxy-2-pyridone 3) underwent a [3+2] cycloaddition reaction with the parent chalcone in the presence of iodobenzene diacetate to provide two 2,3,4,5-tetrasubstituted isoxazolidine isomers (Scheme 15). The regiochemical control of the reaction is consistent with the addition of the nitrone oxygen to the $\beta$-carbon of the chalcone [155].

1,3-Dipolar cycloaddition reaction of chalcones with $\mathrm{N}$-arylaldonitrones afforded two diastereomeric isoxazolidine cycloadducts $4 \mathbf{a}, \mathbf{b}$. Replacing the $N$-aryl group to an $N$-methyl group, three isoxazolidine isomers 4a-c were isolated (Scheme 16) [156].

Four isomers were generated in the reaction of chalcone with $C$ ethoxycarbonyl- $N$-methylnitrone. Using aluminum tris(2,6diphenylphenoxide) (ATPH) as catalyst increased the yields obtained but the low regio- and stereoselectivities remains [157]. The $C$-diethoxyphosphoryl- $N$-methylnitrone $\mathbf{5}$ was used by Piotrowska et al. in the 1,3-dipolar cycloaddition reaction with chalcones to obtain a new series of four isomeric isoxazolidin-3-yl-3phosphonates (Scheme 17). Treating these cycloadducts with trimethylsilyl bromide provided the corresponding phosphonic acids in good to excellent yields [158].

\subsubsection{Transformation of Chalcones to Imidazoles}

Imidazole and its derivatives play an important role in biological systems, particularly in enzymes, acting as both proton donors and/or acceptors, as coordination ligands, and as the base of charge- 


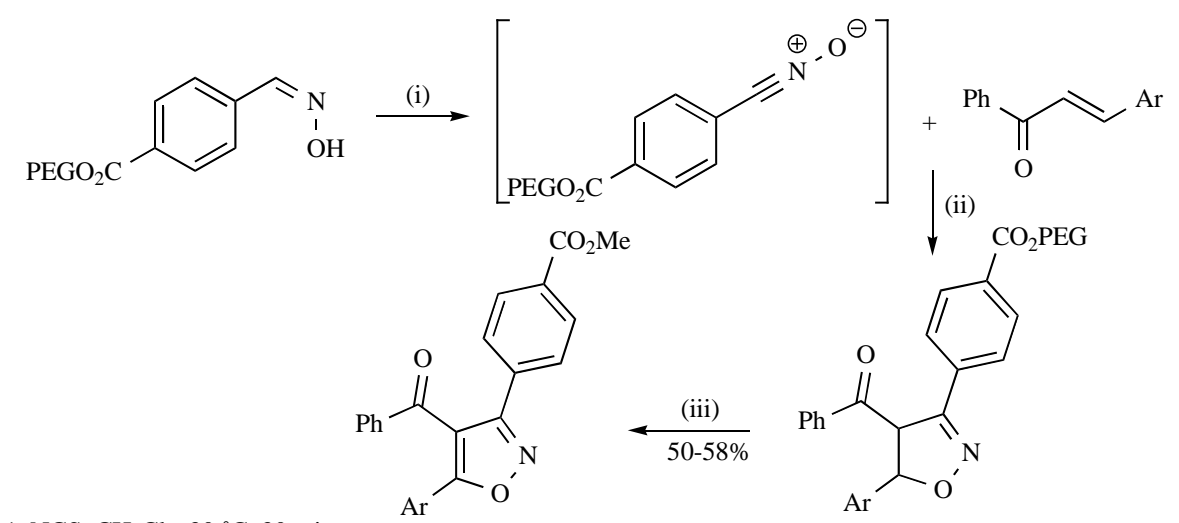

(i) 1. $\mathrm{NCS}, \mathrm{CH}_{2} \mathrm{Cl}_{2}, 30{ }^{\circ} \mathrm{C}, 30 \mathrm{~min}$

(ii) 1. rt, $30 \mathrm{~min}$. 2. $\mathrm{Et}_{3} \mathrm{~N}, \mathrm{CH}_{2} \mathrm{Cl}_{2}$, rt, overnight

$\mathrm{Ar}=\mathrm{Ph}, \mathrm{ClC}_{6} \mathrm{H}_{4}, \mathrm{MeC}_{6} \mathrm{H}_{4}, \mathrm{MeOC}_{6} \mathrm{H}_{4}, \mathrm{NO}_{2} \mathrm{C}_{6} \mathrm{H}_{4}, \mathrm{CH}_{2} \mathrm{O}_{2} \mathrm{C}_{6} \mathrm{H}_{3}$

(iii) $\mathrm{NaOMe}, \mathrm{MeOH}, \mathrm{rt}$

Scheme 14. PEG-supported synthesis of 3,4,5-trisubstituted isoxazolines.

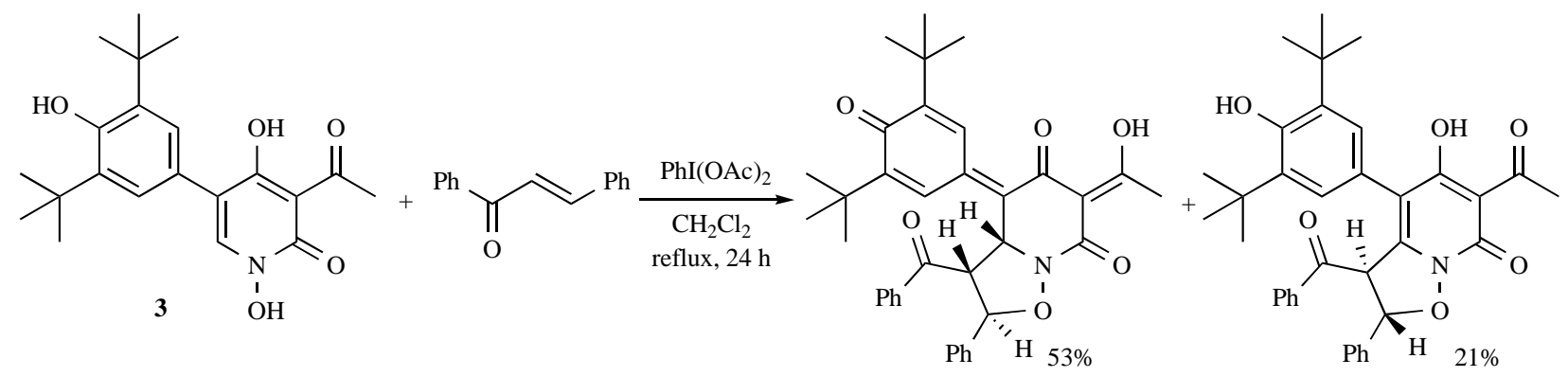

Scheme 15. 1,3-Dipolar cycloaddition reaction of chalcones with nitrone 3 .

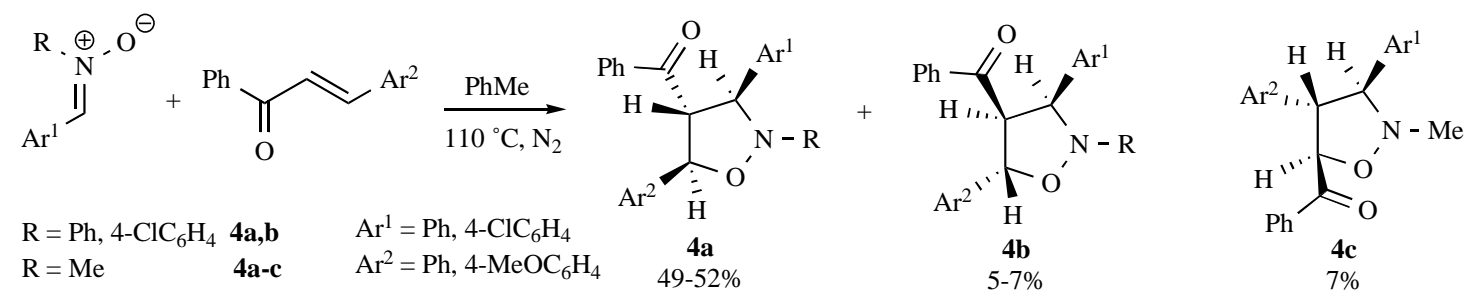

Scheme 16. 1,3-Dipolar cycloaddition reaction of chalcones with $C, N$-disubstituted aldonitrones.

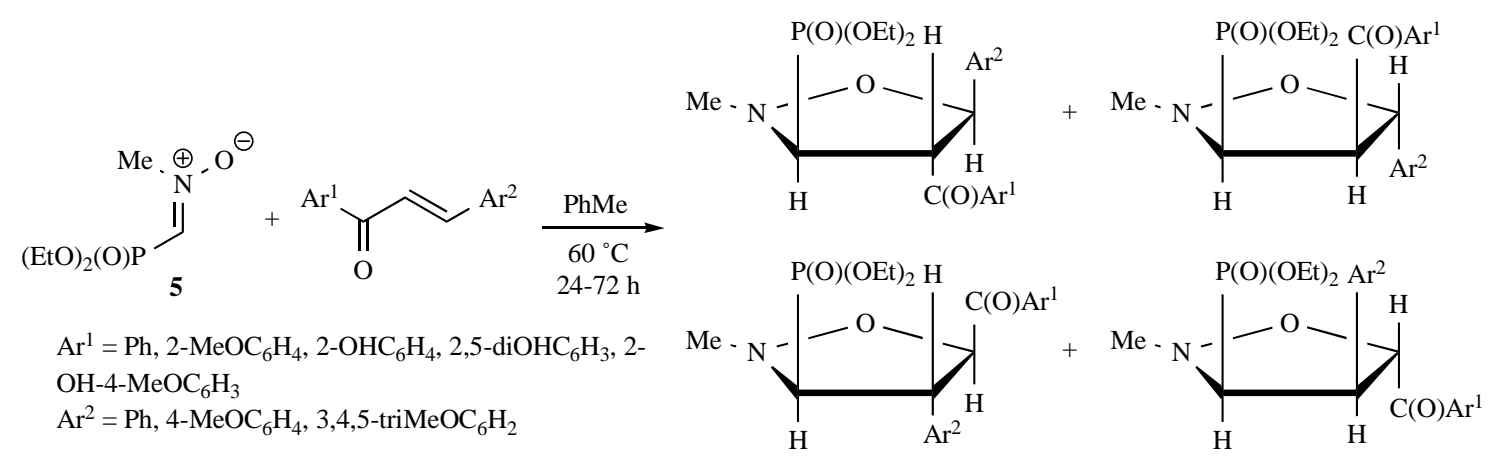

Scheme 17. 1,3-Dipolar cycloaddition reaction of chalcones with $C$-diethoxyphosphoryl- $N$-methyl nitrone 5 .

transfer processes [159]. It was also reported other biological effects such as antitumor [160-162], antimalarial [163], and antifungal activities [164], and tubulin polymerization inhibitors [165, $166]$ of certain of these derivatives.

There are only a couple of references involving the synthesis of imidazoles from chalcones. In 2003 Varga et al. studied the reaction of chalcones with guanidine in the presence of an oxidizing agent in order to establish a new route towards the synthesis of 4,6- diaryl-2-aminopyrimidine derivatives [167]. The authors concluded that depending in the order of reagents addition could obtained either 4,6-diarylpyrimidin-2-ylamine or 2-amino-5,5-disubstituted3,5-dihydroimidazol-4-ones. When the addition of reagents and the oxidizing agent was made at the same time, 2-amino-5,5disubstituted-3,5-dihydroimidazol-4-ones were obtained in moderate yields and their structures confirmed by several NMR techniques and X-ray analysis (Scheme 18) [167]. 


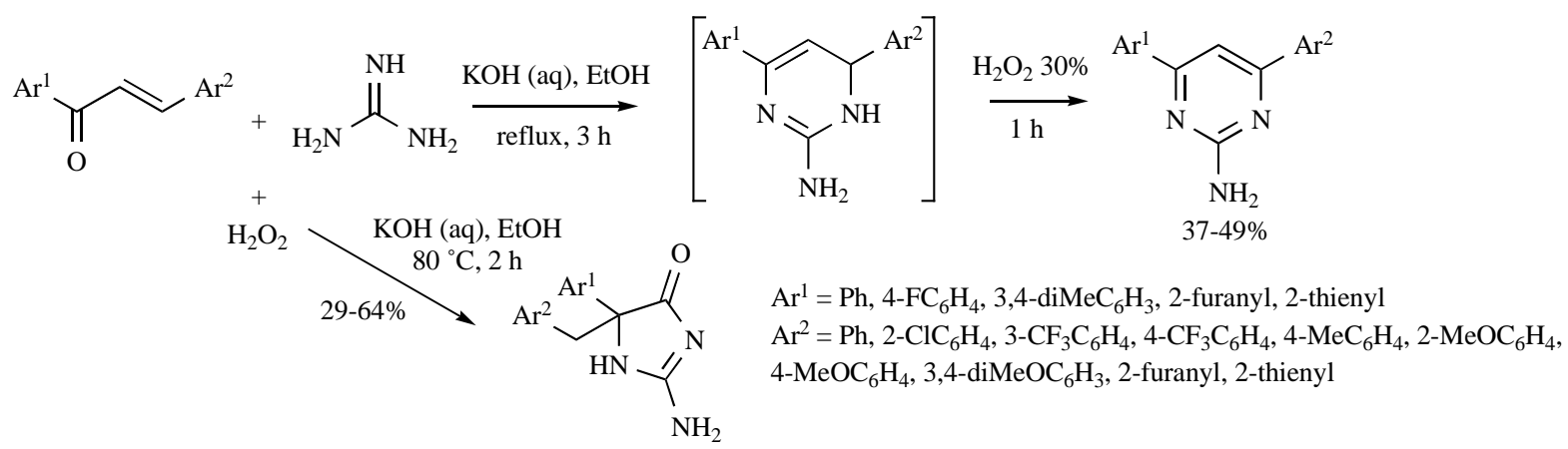

Scheme 18. Reaction of chalcones with guanidine in the presence of an oxidizing agent.

Recently, excellent yields of highly substituted imidazoles were achieved from the multicomponent reaction of $\alpha$-azidochalcones, aryl-aldehydes and anilines mediated by erbium triflate (Scheme 19) [168].

\subsubsection{Transformation of Chalcones to Pyrazoles}

The pyrazole nucleus is present in many bioactive compounds exhibiting a wide range of chemotherapeutic potential. It has been well-documented that some pyrazoles possess antileukemic [169, 170], antitumor [171], and antiproliferative [172, 173] properties, many of them associated to the inhibition of enzymes involved in cell division [174, 175]. Moreover, the introduction of a pyrazole ring between the two aryl rings of chalcones played a remarkable increase in the cytotoxic activity against a series of human cancer cell lines [176].

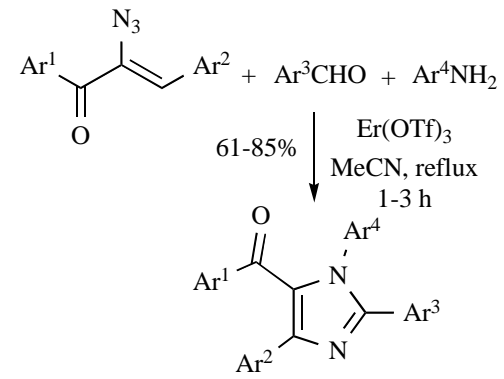

$\mathrm{Ar}^{1}=\mathrm{Ph}, 4-\mathrm{ClC}_{6} \mathrm{H}_{4}, 4-\mathrm{MeC}_{6} \mathrm{H}_{4}, 4-\mathrm{MeOC}_{6} \mathrm{H}_{4}, 4-\mathrm{NO}_{2} \mathrm{C}_{6} \mathrm{H}_{4}$

$\mathrm{Ar}^{2}=\mathrm{Ph}, 3-\mathrm{ClC}_{6} \mathrm{H}_{4}, 4-\mathrm{ClC}_{6} \mathrm{H}_{4}, 4-\mathrm{MeC}_{6} \mathrm{H}_{4}$, 2-thiazolyl

$\mathrm{Ar}^{3}=\mathrm{Ph}, 4-\mathrm{BrC}_{6} \mathrm{H}_{4}, 4-\mathrm{CF}_{3} \mathrm{C}_{6} \mathrm{H}_{4}, 4-\mathrm{ClC}_{6} \mathrm{H}_{4}, 3-\mathrm{MeC}_{6} \mathrm{H}_{4}$,

4- $-\mathrm{MeC}_{6} \mathrm{H}_{4}, 3-\mathrm{MeOC}_{6} \mathrm{H}_{4}, 4-\mathrm{MeOC}_{6} \mathrm{H}_{4}, 4-\mathrm{NO}_{2} \mathrm{C}_{6} \mathrm{H}_{4}$

$\mathrm{Ar}^{4}=\mathrm{Bz}, \mathrm{Ph}, 2-\mathrm{BrC}_{6} \mathrm{H}_{4}, 4-\mathrm{BrC}_{6} \mathrm{H}_{4}, 4-\mathrm{CF}_{3} \mathrm{C}_{6} \mathrm{H}_{4}, 4-\mathrm{ClC}_{6} \mathrm{H}_{4}, 4-$

$\mathrm{FC}_{6} \mathrm{H}_{4}, 4-\mathrm{MeC}_{6} \mathrm{H}_{4}, 4-\mathrm{MeOC}_{6} \mathrm{H}_{4}, 2-\mathrm{Cl}-3-\mathrm{MeOC}_{6} \mathrm{H}_{3}$, 4-morpholinyl

Scheme 19. Synthesis of highly substituted imidazoles from the multicomponent reaction of $\alpha$-azidochalcones, aryl-aldehydes and anilines mediated by erbium triflate.

The reaction of chalcones with dipolar molecules or 1,2binucleophiles is one of the most important practical pathways towards the synthesis of pyrazole derivatives. Chalcones usually have a high polar double bond which gives them the ability to react with dipolar molecules (reaction with diazoalkanes). On the other hand, reaction of chalcones with 1,2-binucleophilic compounds, e.g. hydrazine derivatives, is the most used and well-known approach for the synthesis of pyrazoles. These one-step or two-steps transformations are usually carried under acidic conditions, being ethanol or acetic acid the most common solvents [177-179]. Few derivatives were prepared through the one-pot reactions of chalcones with phenylhydrazine in the presence of iodine [180] or tetrakispyridinecobalt(I) dichromate (TPCD) [181] in acetic acid and with hydrazine hydrate in the presence of iodine in DMSO [182]. Other exam- ples for the one-pot synthesis of pyrazoles under neutral conditions were the condensation of hydrazine hydrate with sugar-chalcones [183] or hydrazine hydrate / phenylhydrazine with $\alpha, \beta$-disubstituted chalcones [99], in refluxing ethanol. Faidallah et al. reported the synthesis of 3,5-disubstituted pyrazoles in a three-step sequence: condensation of chalcones with $p$-sulfamylphenylhydrazine hydrochloride in the presence of NaOAc gave the corresponding hydrazones, subsequent addition of a few drops of hydrochloric acid in ethanol at reflux provided pyrazolines which after oxidation with aqueous bromine afforded the target pyrazoles [184]. Although these methods were reviewed by Chebanov in a book published in 2008, we also have considered here the references that appear since the beginning of the $21^{\text {st }}$ century to be coherent with all the others families of heterocyclic compounds.

A highly efficient and environmentally friendly one-pot method was recently developed for the synthesis of 3,5-diphenyl- $1 \mathrm{H}$ pyrazoles under mechanochemical ball-milling conditions. The advantages of this reaction of chalcones with hydrazine hydrate are the short reaction time, high efficiency, no separation of the in situ generated 2-pyrazoline intermediates, and the use of cheap sodium persulfate as the oxidant, together with a very simple work-up procedure [185].

Chalcones dibromides, obtained from the treatment of chalcones with bromine, afforded pyrazoles by the reaction with benzoylhydrazines [186] and phenylhydrazines [115] in dry pyridine or hydrazines in triethanolamine [187], and 2-pyrazolines by the reaction with phenylhydrazine or isonicotinic acid hydrazide in DMF (Scheme 20) [188]. A series of bispyrazoles can be accomplished through the reaction of bischalcones tetrabromo derivatives with hydrazine hydrate in refluxing methanol [189].

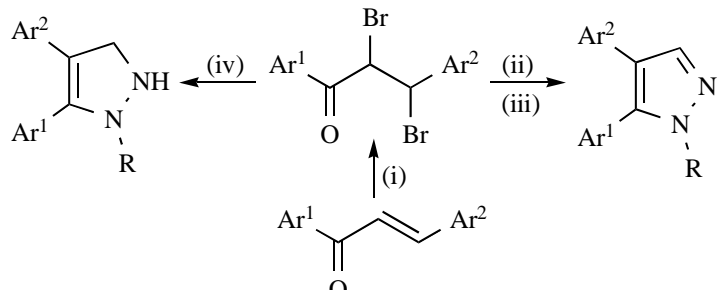
(i) $\mathrm{Br}_{2}, \mathrm{CHCl}_{3}$ or $\mathrm{AcOH}$
(iii) $\mathrm{RNHNH}_{2}$, triethanolamine

(ii) $\mathrm{RNHNH}_{2}$, dry pyridine

(iv) $\mathrm{RNHNH}_{2}$, DMF

Scheme 20. Chalcone dibromides as precursors of pyrazoles and 2pyrazolines.

Following the previous reports concerning the reaction of dibromochalcones towards the synthesis of pyrazoles, Prakash et al. reported a new synthetic route starting from $\alpha, \beta$-ditosylate chalcones. The reaction with phenylhydrazine hydrochloride, semicarbazide hydrochloride and thiosemicarbazide afforded the corre- 
sponding 1,4,5-trisubstituted pyrazoles in moderate to good yields (Scheme 21) [190]. At the same time Aggarwal and co-workers used iodobenzene diacetate for the oxidation of the intermediates $N$ substituted hydrazones from chalcones to afford 1,3,5-trisubstituted pyrazoles under mild conditions in high yields [191].

The one-pot cycloaddition reaction of hydrazine hydrate with chalcone-epoxides followed by dehydration is an efficient and convenient procedure for the preparation of 3,5-diaryl- $1 H$-pyrazoles $[192,193]$. A similar two-steps approach involved the isolation of 4-hydroxypyrazolines [85, 176]. An ecofriendly synthesis of 1,3,5triarylpyrazoles occurs through the one-pot addition-cyclocondensation reaction of chalcones with arylhydrazines in the ionic liquid ([bmim] $\left.\left[\mathrm{PF}_{6}\right]\right)$ promoted by $\mathrm{Cu}(\mathrm{OTf})_{2}$ in good to high yields $(71-84 \%)$ [194].

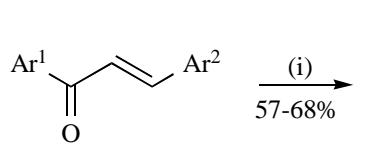

$$
\begin{aligned}
& \text { (i) } \mathrm{HTIB}, \mathrm{CH}_{2} \mathrm{Cl}_{2}, 40{ }^{\circ} \mathrm{C}, 16-18 \mathrm{~h} \\
& \prod_{O}^{\mathrm{OTs}} \mathrm{Ar}^{2} \\
& \overbrace{\mathrm{Ar}^{1}}^{\mathrm{Ar}^{2}} \\
& \text { (ii) } \mathrm{R}=\mathrm{PhNHNH}_{2} \cdot \mathrm{HCl} \text {, DMF, reflux, } 3 \mathrm{~h}, 52-76 \% \mathrm{R} \\
& \mathrm{R}=\mathrm{NH}_{2} \mathrm{CONHNH}_{2} \cdot \mathrm{HCl}, \mathrm{NaOAc}, \mathrm{EtOH} \text {, reflux, 2-3 h, 53-65\% } \\
& \mathrm{R}=\mathrm{NH}_{2} \mathrm{CSNHNH}_{2} \text {, EtOH, reflux, 2-3 h, 59-65\% } \\
& \mathrm{Ar}^{1}=\mathrm{Ph}, 4-\mathrm{ClC}_{6} \mathrm{H}_{4}, 4-\mathrm{MeC}_{6} \mathrm{H}_{4}, 4-\mathrm{MeOC}_{6} \mathrm{H}_{4} \\
& \mathrm{Ar}^{2}=\mathrm{Ph}, 4-\mathrm{BrC}_{6} \mathrm{H}_{4}, 4-\mathrm{MeC}_{6} \mathrm{H}_{4}, 4-\mathrm{MeOC}_{6} \mathrm{H}_{4} \text {, 2-thienyl, } \\
& \text { 3-methyl-2-thienyl, 5-methyl-2-thienyl }
\end{aligned}
$$

Scheme 21. Chalcone ditosylates as precursors of pyrazoles

$$
\begin{aligned}
& \text { (i) } \mathrm{Pd} / \mathrm{C} / \mathrm{K}-10, \mathrm{MW}, 160{ }^{\circ} \mathrm{C}, 20-30 \mathrm{~min} \\
& \mathrm{R}=\mathrm{Me}, \mathrm{Ph}, 3-\mathrm{CF}_{3} \mathrm{C}_{6} \mathrm{H}_{4}, 4-\mathrm{NO}_{2} \mathrm{C}_{6} \mathrm{H}_{4} \\
& \mathrm{Ar}^{1}=\mathrm{Ph}, 4-\mathrm{FC}_{6} \mathrm{H}_{4}, 4-\mathrm{MeC}_{6} \mathrm{H}_{4}, 4-\mathrm{MeOC}_{6} \mathrm{H}_{4} \\
& \mathrm{Ar}^{2}=\mathrm{Ph}, 4-\mathrm{FC}_{6} \mathrm{H}_{4}
\end{aligned}
$$

Scheme 22. Microwave-assisted one-pot synthesis of pyrazoles catalyzed by $\mathrm{Pd} / \mathrm{C} / \mathrm{K}-10$ montmorillonite.

Under microwave irradiation, a range of 3,5-disubstitued pyrazoles was prepared when chalcones react with hydrazine hydrate $[151,195]$. Better yields and shorter reaction times were observed when compared with classic heating methods. A similar approach was developed for the reaction with p-toluenesulfonylhydrazide in DMF [196]. Landge et al. reported a good example of a one-pot solvent-free microwave assisted synthesis of pyrazoles using a bifunctional noble-metal/solid-acid catalyst, $\mathrm{Pd} / \mathrm{C} / \mathrm{K}-10$ montmorillo- nite (Scheme 22). The reaction of chalcones with substituted hydrazines provided 1,3,5-trisubstituted pyrazoles in good to excellent yields with high selectivity $(85-100 \%)$. In some cases, small amounts of 2-pyrazolines were also isolated [197].

The most common approach for the synthesis of 2-pyrazolines starting from chalcones involves the reaction with hydrazines in refluxing ethanol [93, 113, 198-209] or methanol [113, 125, 133, 210]. Under these conditions, a large variety of substituents can be found in the synthesis of functionalized 2-pyrazolines such as benzodioxane [211], benzofuran [118, 212, 213], coumarin [214], indenoquinoxaline [215], naphthalene [125], quinoline [216, 217], 1,3-thiazole [218] and thiophene [219-221]. The introduction of bases such as pyridine [122, 222-224], piperidine [129, 225, 226], triethylamine [227, 228], $\mathrm{KOH}$ [107], $\mathrm{NaOH}$ [229-241] and $\mathrm{NaOAc}$ [242] or acids as formic [243, 244], acetic [82, 108, 116, 131, 208, $243,245-248]$, hydrochloric [249, 250] and sulfuric [130] led to other functionalized derivatives. Alternative solvents for this type of reaction are acetic acid [106, 251-272], formic acid [251, 252, 273], pyridine [274, 275], acetic acid/pyridine [276], THF [22], triethanolamine [126], dioxane [137, 277, 278] and propan-1-ol [279].

Smuilovich et al. studied the reaction of polyfluorinated chalcones with hydrazines in boiling acetic acid. Cycloaddition of hydrazine hydrate to chalcones $6 \mathrm{a}$ and $6 \mathrm{~b}$ provided polyfluorinated 1acetyl-3,5-diarylpyrazolines $\mathbf{7 a}$ and $\mathbf{7 b}$. Different results were obtained from the reaction with phenylhydrazine: chalcones $6 \mathbf{a}$ gave the expected triarylpyrazolines $\mathbf{8 a}$, while chalcones $\mathbf{6 b}$ led to an equimolar amount of two regioisomeric pyrazolines at the positions C-3 and C-5 8b and 8c (Scheme 23) [280]. Using the same conditions, a series of pyrazolyl-2-pyrazolines arise from the reaction of chromone-derived chalcones with an excess of phenylhydrazine. Here, both the chromone and the $\alpha, \beta$-unsaturated ketone moieties are implicated in the attack of phenylhydrazine to afford respectively, the pyrazole and pyrazoline units [281]. A wide variety of chalcones afforded 1-acetyl- or 1-phenyl-3,5-diaryl-2-pyrazolines from the reaction with hydrazine hydrate or phenylhydrazine in refluxing acetic acid, respectively [274, 282-285]. 1-Chloroacetyland 1-propionyl-3,5-diaryl-2-pyrazolines arise from the reaction of chalcones with hydrazine hydrate in chloroacetic acid [286] and propionic acid [274, 285], respectively. The condensation of a range of chalcones with several acid hydrazides provided 1-acyl3,5-diaryl-2-pyrazolines, using acetic acid as solvent [287, 288]. The synthesis of 3,5-diaryl-1-(5-tetrazolyl)-2-pyrazolines can be achieved through two general routes: reaction of chalcones with 1,5-diaminotetrazole in DMF at $150{ }^{\circ} \mathrm{C}$ or with 5tetrazolohydrazine in refluxing ethanol [289].

The introduction of substituents in the hydrazine molecule can change the most reactive nitrogen atom, and thus give a different

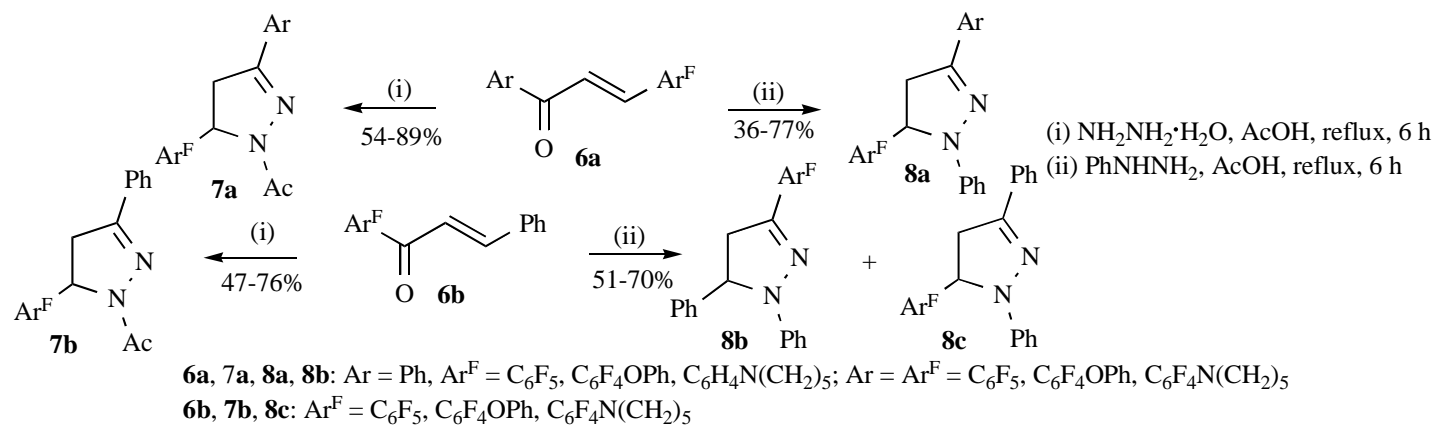

Scheme 23. Synthesis of polyfluorinated 3,5-diarylpyrazolines. 
pyrazole isomer as reported by Kumara et al. [290]. The reaction of 3-chlorobenzo[b]thiophene-2-carboxyhydrazide with chalcones using a catalytic amount of acetic acid in 1,4-dioxane afforded a less common pyrazoline isomer (Scheme 24). A similar approach uses naphtha[2,1-b]furan-2-carboxyhydrazide [291].

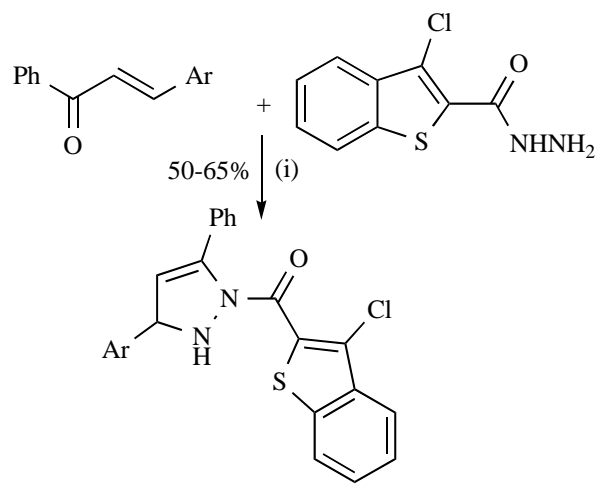

(i) $\mathrm{AcOH}, 1,4$-dioxane, reflux, $26 \mathrm{~h}$

$\mathrm{Ar}=\mathrm{Ph}, 4-\mathrm{ClC}_{6} \mathrm{H}_{4}, 4-\mathrm{NO}_{2} \mathrm{C}_{6} \mathrm{H}_{4}$

Scheme 24. Reaction of chalcones with 3-chloro-benzo[b]thiophene-2carboxyhydrazide.

$$
\begin{aligned}
& \mathrm{R}={ }^{t} \mathrm{Bu}, \mathrm{Et},{ }^{2} \mathrm{Pr} \\
& \mathrm{Ar}^{1}=\mathrm{Ph}, 4-\mathrm{BrC}_{6} \mathrm{H}_{4}, 4-\mathrm{ClC}_{6} \mathrm{H}_{4}, 4-\mathrm{MeOC}_{6} \mathrm{H}_{4}, 4-\mathrm{NO}_{2} \mathrm{C}_{6} \mathrm{H}_{4} \\
& \mathrm{Ar}^{2}=\mathrm{Ph}, 4-\mathrm{CF}_{3} \mathrm{C}_{6} \mathrm{H}_{4}, 2-\mathrm{ClC}_{6} \mathrm{H}_{4}, 3-\mathrm{ClC}_{6} \mathrm{H}_{4}, 4-\mathrm{ClC}_{6} \mathrm{H}_{4}, 4-\mathrm{FC}_{6} \mathrm{H}_{4}, \\
& 4-\mathrm{MeOC}{ }_{6} \mathrm{H}_{4}, 9-\text {-antryl, 2-furyl, naphthyl }
\end{aligned}
$$

Scheme 25. Reaction of chalcones with "Huisgen zwitterions".

The reaction of chalcones with "Huisgen zwitterions", derived from dialkyl azodicarboxylates and triphenylphosphane, provided a series of highly functionalized 2-pyrazolines (Scheme 25) [292].

Bispyrazolines have been achieved through the cycloaddition of bischalcones with hydrazine hydrate in acetic/formic acids [293, 294], methanol [189] or DMF at reflux [295] or with thiosemicarbazides under basic conditions [296] (Scheme 26).

Numerous biologically active $N$-unsubstituted or $N$-substituted 2-pyrazolines have been prepared from the reaction of chalcones with hydrazine hydrate or hydrazine derivatives, respectively [136, 143, 297-306].

Similar to the stereospecific synthesis of chiral isoxazolines from oximes of chiral Michael adducts of thiophenols to chalcones, Zielinska-Błajet et al. extended their study to the reaction with the $\mathrm{N}$-arylhydrazones of the Michael adduct to afford chiral 2pyrazolines [144].

In 2008 Xie et al. reported a novel synthesis of substituted 2pyrazolines using chlorotrimethylsilane (TMSCl) as a Lewis acid to promote the cyclization reaction of chalcones with phenylhydrazine in good yields (Scheme 27) [307].

1,5,7-Triazabicyclo[4.4.0]dec-5-ene (TBD) catalyzed the reaction of chalcones with a range of acylhydrazines giving access to 3,5-diaryl-2-pyrazolines in good yields. The reaction proceeds through a regioselective alkylation of the secondary amine moiety of hydrazines and the products possess an electron-withdrawing group at N-1 (Scheme 28) [308].

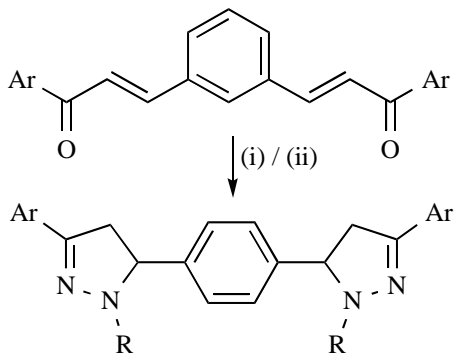

(i) $\mathrm{Ar}=\mathrm{Ph}, 4-\mathrm{BrC}_{6} \mathrm{H}_{4}, 4-\mathrm{ClC}_{6} \mathrm{H}_{4}, 2,4-\mathrm{ClC}_{6} \mathrm{H}_{3}, 4-\mathrm{FC}_{6} \mathrm{H}_{4}$, 4- $\mathrm{MeOC}_{6} \mathrm{H}_{4}, 4-\mathrm{NO}_{2} \mathrm{C}_{6} \mathrm{H}_{4} ; \mathrm{R}=\mathrm{NH}_{2} \mathrm{NH}_{2}$, DMF, reflux, $5 \mathrm{~h}$ (ii) $\mathrm{Ar}=\mathrm{Ph} ; \mathrm{R}=\mathrm{NH}_{2} \mathrm{NHCSN}$-substituted, $\mathrm{NaOH}, \mathrm{EtOH}$, reflux, $72 \mathrm{~h}$

Scheme 26. Synthesis of bispyrazolines from bischalcones.

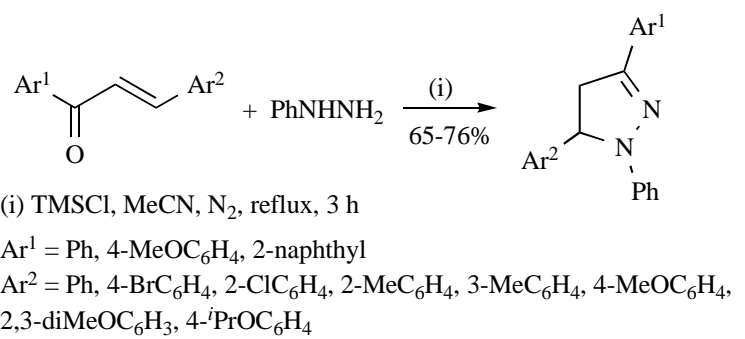

Scheme 27. Synthesis of 1,3,5-trisubstituted 2-pyrazolines mediated by chlorotrimethylsilane.

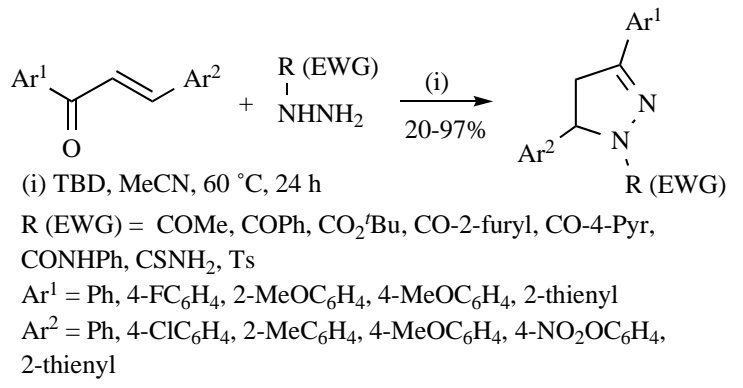

Scheme 28. Regioselective addition of acylhydrazines to chalcones promoted by TBD.

1,3,5-Triaryl-2-pyrazolines were synthesized in high yields from chalcones and phenylhydrazine, using an heterogeneous catalyst constructed from polyoxometalate $\left(\mathrm{H}_{3} \mathrm{PW}_{12} \mathrm{O}_{40}\right)$ and poly(amidoamine) ( $\left.\mathrm{PW}_{12} / \mathrm{PA}\right)$ [309]. One year later, the same author reported this reaction using another heterogeneous catalyst based on CsHPW $\left(\mathrm{Cs}_{2.5} \mathrm{H}_{0.5} \mathrm{PW}_{12} \mathrm{O}_{40}\right)$ nanocrystals [310]. The reaction afforded two different isomers, depending on the catalyst used (Scheme 29).

The enantioselective synthesis of 3,5-diaryl-2-substituted-2pyrazolines was achieved through an aza-Michael-cyclocondensation cascade addition of $\mathrm{N}$-Boc hydrazine or (thio)semicarbazides to chalcones, under phase transfer organocatalytic conditions (Scheme 30) [311].

Substituted 2-pyrazolines were achieved when chalcones react with phenylhydrazine using an imidazolium-based ionic liquid $\{1,2$ [bis-(3'-methyl-imidazolium hydrogen sulfate)]ethane $\}$ that acts as both solvent and catalyst [312]. A novel one-pot synthesis of pyrazoles and pyrazolines was reported in 2012, starting from aryl halides, styrenes, carbon monoxide and hydrazines. The reaction 
involves the palladium-catalysed carbonylative vinylation of aryl halides to give the corresponding chalcones (Scheme 31a) [313], which undergo in situ cyclocondensation with hydrazines to afford 2-pyrazolines (Scheme 31b). Further oxidation with DDQ at room temperature for 2 hours provided pyrazoles in moderate overall yields for the three-step sequence [314].

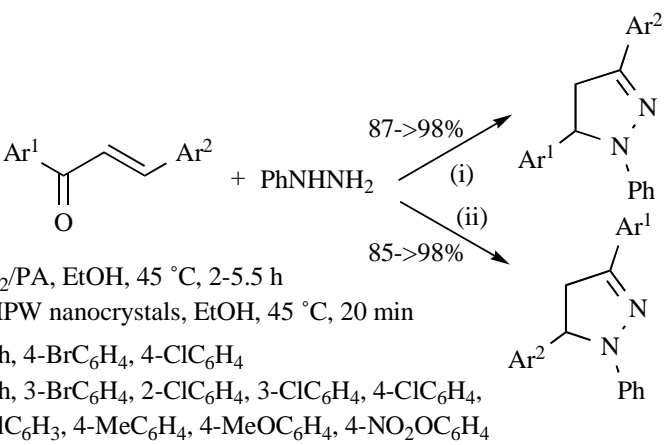

Scheme 29. Synthesis of 1,3,5-triaryl-2-pyrazolines using heterogeneous catalysts.

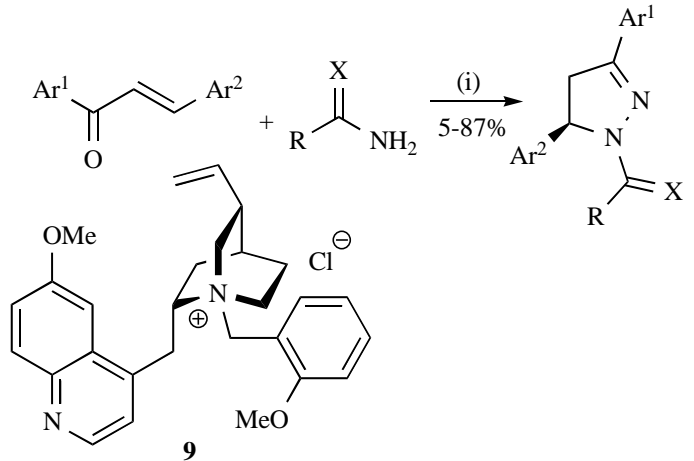

(i) $9, \mathrm{Cs}_{2} \mathrm{CO}_{3}, \mathrm{THF}, 0{ }^{\circ} \mathrm{C}, 24 \mathrm{~h}$

$\mathrm{Ar}^{1}=\mathrm{Ar}^{2}=\mathrm{Ph}, \mathrm{R} / \mathrm{X}=\mathrm{PhNH} / \mathrm{O}, \mathrm{NH}_{2} / \mathrm{S}, \mathrm{O}^{t} \mathrm{Bu} / \mathrm{O}$

$\mathrm{Ar}^{1}=4-\mathrm{OTHPC}_{6} \mathrm{H}_{4}, \mathrm{Ar}^{2}=2-\mathrm{ClC}_{6} \mathrm{H}_{4}, \mathrm{R} / \mathrm{X}=\mathrm{O}^{t} \mathrm{Bu} / \mathrm{O}$

Scheme 30. Enantioselective synthesis of 3,5-diaryl-2-pyrazolines under phase transfer organocatalytic conditions.

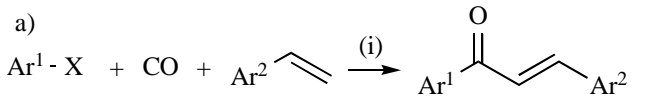

(i) [(cinnamyl) $\left.\mathrm{PdCl}_{2}\right], \mathrm{PPh}_{3}, \mathrm{DMF}, \mathrm{NEt}_{3}$

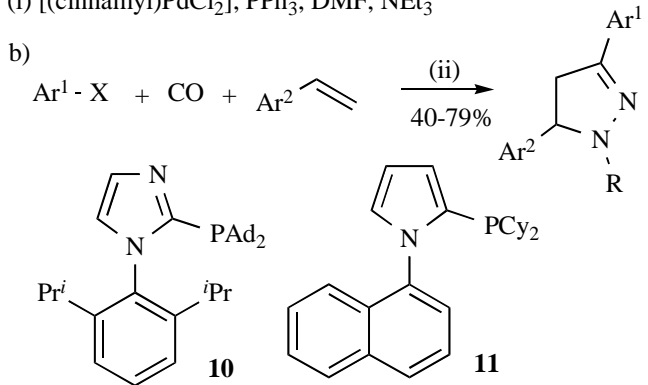

(ii) 1. [(cinnamyl) $\left.\mathrm{PdCl}_{2}\right], \mathbf{1 0}$ or $\mathbf{1 1}, \mathrm{Et}_{3} \mathrm{~N}, 100-120{ }^{\circ} \mathrm{C}, 20 \mathrm{~h}$.

2. $\mathrm{RNHNH}_{2}, \mathrm{rt}, 1 \mathrm{~h}$

$\mathrm{X}=\mathrm{Br}, \mathrm{I}$

$\mathrm{R}=\mathrm{Me}, \mathrm{Bn}, \mathrm{CH}_{2} \mathrm{CF}_{3}$

$\mathrm{Ar}^{1}=\mathrm{Ph}, 4-\mathrm{BrC}_{6} \mathrm{H}_{4}, 4-{ }^{t} \mathrm{BuC}_{6} \mathrm{H}_{4}, 4-\mathrm{ClC}_{6} \mathrm{H}_{4}, 4-\mathrm{EtC}_{6} \mathrm{H}_{4}, 4-\mathrm{FC}_{6} \mathrm{H}_{4}$,

4- $\mathrm{MeC}_{6} \mathrm{H}_{4}, 3,5$-diMeC $\mathrm{di}_{3}, 4-\mathrm{MeOC}_{6} \mathrm{H}_{4}, 3$-thienyl

$\mathrm{Ar}^{2}=\mathrm{Ph}, 4-{ }^{-} \mathrm{BuC}_{6} \mathrm{H}_{4}, 4-\mathrm{ClC}_{6} \mathrm{H}_{4}, 4-\mathrm{FC}_{6} \mathrm{H}_{4}, 4-\mathrm{MeOC}_{6} \mathrm{H}_{4}$

Scheme 31. One-pot synthesis of 3,5-diaryl-2-pyrazolines starting from aryl halides, styrenes, carbon monoxide and hydrazines.
The synthesis of 2-pyrazolines by the reaction of chalcones with hydrazines generally occurs in good yields. However, the constant seek for new mild and ecofriendly processes are still on. Thus, a green and efficient protocol for the synthesis of 3,5-disubstituted 2-pyrazolines was achieved by the reaction of chalcones with hydrazine hydrate under irradiation with tungsten light. The reaction occurs with no need of catalyst and in a short reaction time giving quantitative yields of the 2-pyrazolines (Scheme 32) [315].<smiles>[R]c1cc(C(=O)/C=C/[14CH2]N)c(O)c2ccccc12</smiles>

(i) AcOH, 2-methoxyethanol, tungsten light $(100 \mathrm{~W}), 25-32 \mathrm{~min}$ $\mathrm{R}=\mathrm{H}, \mathrm{Br}, \mathrm{I}$

$\mathrm{Ar}=3-\mathrm{Br}-4,5-\mathrm{diMeOC}_{6} \mathrm{H}_{2}, 4-\mathrm{ClC}_{6} \mathrm{H}_{4}, 4-\mathrm{FC}_{6} \mathrm{H}_{4}, 4-\mathrm{MeOC}_{6} \mathrm{H}_{4}$

Scheme 32. Synthesis of 3,5-disubstituted 2-pyrazolines using irradiation of a tungsten light.

Poly(ethyleneglycol) (PEG)-400 was used as an alternative solvent in the synthesis of 1-thiazolyl-2-pyrazoline derivatives starting from 4-(4'-chlorophenyl)-2-hydrazinothiazole and chalcone-type compounds. The reaction occurred in the presence of $\mathrm{NaOH}$ at 80 ${ }^{\circ} \mathrm{C}$, in excellent yields [316]. Using the same solvent, a series of 2pyrazoline derivatives containing an imidazole moiety was synthetized by the treatment of chalcones with hydrazine hydrate and phenylhydrazine [317].

Some authors reported the synthesis of 2-pyrazolines starting from chalcones and hydrazines using microwave assisted reactions [318-325] and in some cases, even in solvent-free conditions [326, 327]. Several improvements were also achieved under microwave irradiation in the reaction of hydrazines with chalcones containing indole [328, 329], pyrazole [330], quinolone [331] and benzimidazole [332] moieties. The synthesis of pyrazolyl-2-pyrazolines occurred under solvent-free conditions in the absence of any acidic or basic catalyst [333]. Comparative studies indicate that a reduction in the time of reaction and better yields were accomplished (Scheme 33).<smiles>[R][R]O[R]([R])=O</smiles>

(i) $\mathrm{NH}_{2} \mathrm{NH}_{2}, \mathrm{EtOH}$, pyridine, reflux, 35 min-14 h, 66-78\%

(ii) $\mathrm{NH}_{2} \mathrm{NH}_{2}, \mathrm{MeOH}$, piperidine, reflux, 25 min-142h, 64-73\%

(iii) $\mathrm{NH}_{2} \mathrm{NH}_{2}, \mathrm{AcOH}, \mathrm{NaOAc}$, reflux, 45 min-20 h, 62-76\%

(iv) $\mathrm{NH}_{2} \mathrm{NH}_{2}, 80{ }^{\circ} \mathrm{C}, 5-20 \mathrm{~min}, 82-91 \%$

Scheme 33. Synthesis of pyrazolyl-2-pyrazolines using conventional heating or thermal solvent-free heating. 
Sharma et al. synthetized substituted 2-pyrazolines from the reaction of chalcones with hydrazine hydrate or phenylhydrazine using green techniques: solvent-free conditions, grindstone method and microwave irradiation [334]. Other grindstone approach [335] and the use of solid supports such as basic alumina under microwave irradiation $[154,336]$ and $\mathrm{K}_{2} \mathrm{CO}_{3}$ [153] provided the target 2pyrazolines in high yields in a few minutes instead of few hours regarding the case of thermal activation.

Ultrasound irradiation can also be used and presents similar advantages to microwave irradiation. Good yields, shorter reaction times and mild conditions were generally obtained when compared with conventional methods [337]. Good yields were achieved in the reaction of chalcones with hydrazines using this green technique [338-340]. A different isomer was obtained when pyrazole-derived chalcones react with hydrazine hydrate in the presence of acetic acid in ethanol, under ultrasonic irradiation (Scheme 34) [341].

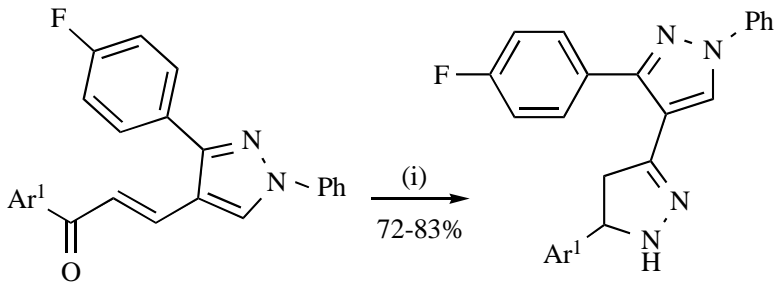

(i) $\mathrm{NH}_{2} \mathrm{NH}_{2} \cdot \mathrm{H}_{2} \mathrm{O}$, ultrasound, $\mathrm{AcOH}$, EtOH, rt, 10-15 min

$\mathrm{Ar}^{1}=\mathrm{Ph}, 4-\mathrm{BrC}_{6} \mathrm{H}_{4}, 4-\mathrm{ClC}_{6} \mathrm{H}_{4}, 4-\mathrm{FC}_{6} \mathrm{H}_{4}, 4-\mathrm{MeC}_{6} \mathrm{H}_{4}$

Scheme 34. Synthesis of 3,5-disubstituted 2-pyrazolines under ultrasound irradiation.

A totally different approach for the synthesis of 3,4disubstituted 2-pyrazolines consisted in the reaction of chromonederived chalcones with diazomethane. This 1,3-dipolar cycloaddition reaction is carried out in an equimolar mixture of chloromethane and diethyl ether at $0{ }^{\circ} \mathrm{C}$ to provide 3-aroyl-4-(3chromonyl)-2-pyrazolines in good yields (Scheme 35) [342].

The diastereoselective 1,3-dipolar cycloaddition reaction of trifluoromethylated $\mathrm{N}$-monosubstituted phenylhydrazone with chalcones were conditions-controlled: using triflic acid as catalyst at room temperature afforded pyrazolidines while in the presence of the catalytic system copper(II) triflate in trifilic acid, a range of 2pyrazolines were obtained (Scheme 36) [343].

\subsubsection{Transformation of Chalcones to Indazoles}

Indazole moiety is rather scarce in natural products, and maybe for this reason there are limited number of publications on indazole chemistry [344]. However, indazole derivatives were extensively studied as bioactive compounds, such as anti-aggregator and vasorelaxant activity by NO release, increase of cGMP levels and anticancer effects, antimicrobial and antiparasitic properties, among others. Recently, the research and development in the medicinal chemistry of these systems have produced compounds with contraceptive activities for men, for the treatment of osteoporosis, inflammatory disorders and neurodegenerative diseases [345].

Michael addition of ethyl acetoacetate to chalcones in the presence of base gave the corresponding cyclohexenone derivatives, after internal Claisen condensation. Further treatment with hydrazine hydrate can convert these intermediates into the corresponding 2,3,4,5-tetrahydro-1H-indazol-3-ones (Scheme 37) [346-350].

Under the same conditions, microwave irradiation was used to synthesize indazole derivatives. A wide range of 2,3,4,5-tetrahydro$1 H$-indazol-3-ones were prepared when 2'-hydroxychalcones re-<smiles>NCC(=O)/C=C/c1coc2ccccc2c1=O</smiles>

(i) $\mathrm{CH}_{3} \mathrm{Cl} /$ diethyl ether $(1: 1), 0{ }^{\circ} \mathrm{C}, 48 \mathrm{~h}$ $\mathrm{Ar}=\mathrm{Ph}, 4-\mathrm{BrC}_{6} \mathrm{H}_{4}, 4-\mathrm{ClC}_{6} \mathrm{H}_{4}, 4-\mathrm{FC}_{6} \mathrm{H}_{4}$, $4-\mathrm{MeC}_{6} \mathrm{H}_{4}, 4-\mathrm{MeOC}_{6} \mathrm{H}_{4}$

Scheme 35. Synthesis of 3,4-disubstituted 2-pyrazolines starting from chromone-derived chalcones and diazomethane.

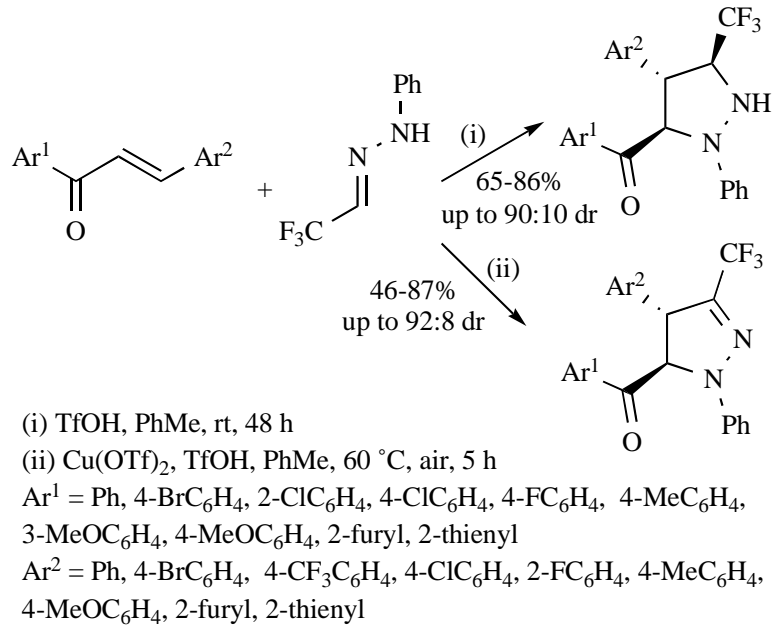

Scheme 36. Diastereoselective synthesis of pyrazolidines and 2-pyrazolines from the reaction of trifluoromethylated $N$-monosubstituted phenylhydrazone with chalcones.

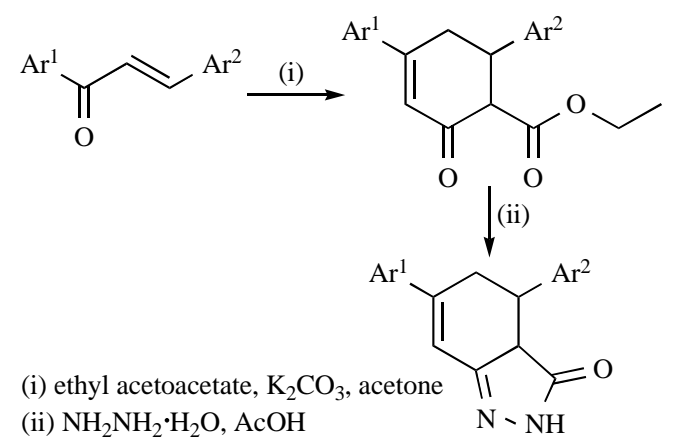

Scheme 37. Synthesis of 2,3,4,5-tetrahydro- $1 H$-indazol-3-ones from chalcones.

acted with ethyl acetoacetate in the presence of either $\mathrm{K}_{2} \mathrm{CO}_{3}$ in acetone or under solvent-free conditions using basic alumina and subsequent condensation with hydrazine hydrate [351]. Starting from benzimidazolylchalcones a series of 2,3,4,5-tetrahydro- $1 \mathrm{H}$ indazol-3-ones were obtained [352] while with typical chalcones it were isolated 4,5-dihydro-2H-indazol-3-ols [353] (Scheme 38). The same good yields that the conventional heating methods or even better were accomplished in a shorter reaction time. 
Bischalcones, obtained from the reaction of benzaldehydes with cyclohexanones, can react directly with phenylhydrazine in the presence of pyridine to yield 2,3-diaryl-7-benzylidene-4,5,6,7tetrahydro-2H-indazoles (Scheme 39) [354].

A new tandem approach for the synthesis of benzindazoles from $o$-alkynylarene chalcones and hydrazines has appeared. This method involves an iodine-promoted tandem oxidative cyclocondensation to provide $o$-alkynylarylpyrazoles which after electrophilic hydroarylation yielded benzo[ $g$ ]indazoles (Scheme 40) [105].

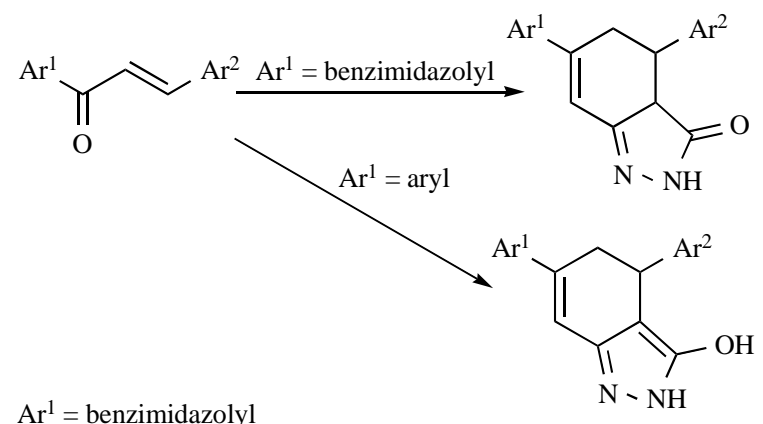

Classical conditions: 1. ethyl acetoacetate, piperidine, basic $\mathrm{Al}_{2} \mathrm{O}_{3}$, EtOH, reflux, 5-7 h; 2. $\mathrm{NH}_{2} \mathrm{NH}_{2} \cdot \mathrm{H}_{2} \mathrm{O}, \mathrm{EtOH}$, reflux, 5-7 h.

MW: 1. ethyl acetoacetate, piperidine, basic $\mathrm{Al}_{2} \mathrm{O}_{3}$, MW, 3-5 min; 2. $\mathrm{NH}_{2} \mathrm{NH}_{2} \cdot \mathrm{H}_{2} \mathrm{O}$, MW, 4-6 min

$\mathrm{Ar}^{1}=$ aryl

Classical conditions: 1 . ethyl acetoacetate, $\mathrm{K}_{2} \mathrm{CO}_{3}$, acetone, $\mathrm{rt}, 5 \mathrm{~h}$;

2. $\mathrm{NH}_{2} \mathrm{NH}_{2} \mathrm{H}_{2} \mathrm{O}, \mathrm{AcOH}, \mathrm{EtOH}$, reflux, $6 \mathrm{~h}$.

MW: 1. ethyl acetoacetate, $\mathrm{K}_{2} \mathrm{CO}_{3}$, silica, MW, 6-8 mim;

2. $\mathrm{NH}_{2} \mathrm{NH}_{2} \mathrm{H}_{2} \mathrm{O}, \mathrm{AcOH}, \mathrm{EtOH}, \mathrm{MW}, 3$ min.

Scheme 38. Synthesis of 2,3,4,5-tetrahydro- $1 H$-indazol-3-ones or 4,5dihydro- $2 \mathrm{H}$-indazol-3-ols starting from chalcone derivatives.<smiles>[R]C1CCc2c(nn(-c3ccccc3)c2[Al])C1=C[Al]#C[Al]/C=C1/C(=O)/C(=C/[Al])CCC1[R]</smiles>

(i) $\mathrm{PhNHNH}_{2}, \mathrm{EtOH}$, pyridine, reflux, $3 \mathrm{~h}$

$\mathrm{R}=\mathrm{H}, \mathrm{Me}$

$\mathrm{Ar}=\mathrm{Ph}, \mathrm{CF}_{3} \mathrm{C}_{6} \mathrm{H}_{4}, \mathrm{ClC}_{6} \mathrm{H}_{4}, \mathrm{FC}_{6} \mathrm{H}_{4}, \mathrm{MeC}_{6} \mathrm{H}_{4}, \mathrm{MeOC}_{6} \mathrm{H}_{4}$

Scheme 39. Synthesis of 2,3-diaryl-7-benzylidene-4,5,6,7-tetrahydro- $2 \mathrm{H}$ indazoles from bischalcones.<smiles>[R]c1cc(C#C[Al])c(/C=C/C(=O)[Al])cc1[R]</smiles>

(i) $\mathrm{R}^{2} \mathrm{NHNH}_{2}, \mathrm{I}_{2}, \mathrm{AcOH}$, reflux, $8 \mathrm{~h}$

$$
\begin{array}{ll}
\mathrm{R}^{1}=\mathrm{H}, \mathrm{MeO} & \mathrm{Ar}^{1}=\mathrm{Ph}, 4-\mathrm{BrC}_{6} \mathrm{H}_{4}, 4-\mathrm{MeOC}_{6} \mathrm{H}_{4} \\
\mathrm{R}^{2}=\mathrm{H}, \mathrm{Ph}, 4-\mathrm{BrC}_{6} \mathrm{H}_{4} & \mathrm{Ar}^{2}=\mathrm{Ph}, 4-\mathrm{MeOC}_{6} \mathrm{H}_{4}
\end{array}
$$

Scheme 40. Iodine-mediated tandem oxidative cyclocondensation of $o$ alkynylarene chalcones with hydrazines.

A three-step sequence was developed to prepare 1,3-diaryl-6,7dimethoxy- $1 H$-benzo[ $g]$ indazoles from chalcones. The reaction with arylhydrazines followed by DDQ-mediated aromatization afforded pyrazole intermediates, which underwent oxidative cleavage annulation in the presence of $\mathrm{OsO}_{4} / \mathrm{NaIO}_{4} / \mathrm{AcOH}$ (Scheme 41) [355].

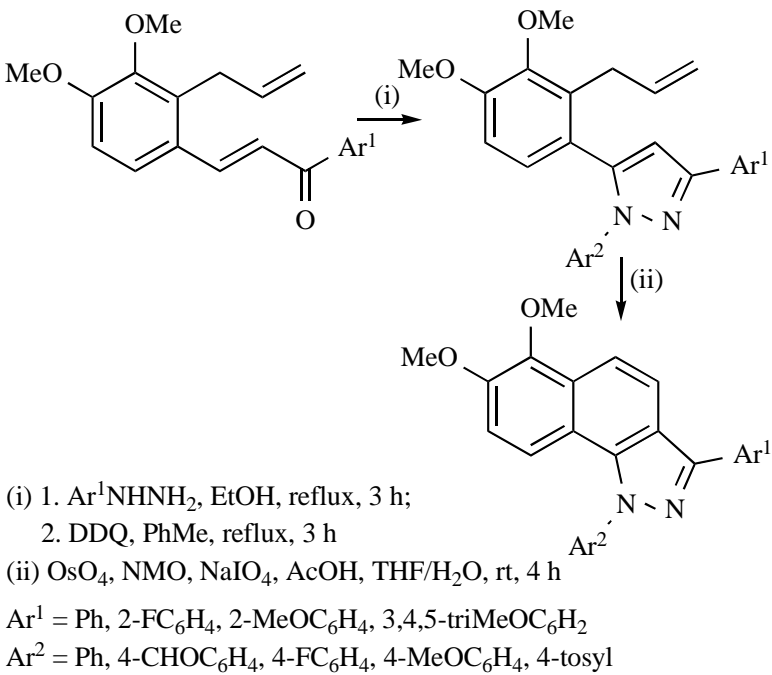

Scheme 41. Synthesis of 1,3-diaryl-6,7-dimethoxy-1H-benzo[ $g]$ indazoles

\subsubsection{Transformation of Chalcones to Triazoles and Tetrazoles}

Triazoles have been applied in various research fields such as biochemistry, pharmaceutical, and material science. Thus, triazoles are used as drugs [356-358] and present a range of biological properties, such as anti-HIV-type I protease [359], antihyperglycemic [360], and antimicrobial [361] activities. In addition, they are commercially used as anticorrosive agents [362], agrochemicals [363], photostabilizers and dyes [364].

1,3-Dipolar cycloaddition of azides to electron poor alkenes and alkynes (dipolarophiles) leads to 1,2,3-triazoles. This approach is the most common method for the synthesis of 1,2,3-triazoles from chalcones.

In 2012, Zhang et al. exploited a one-pot three-component oxidative cycloaddition reaction of chalcones with sodium azide catalyzed by $\mathrm{CuO}$, followed by post-triazole arylation in order to prepare $N$-2-aryl-substituted 1,2,3-triazoles in high yields and with high regioselectivity (Scheme 42) [365]. Chalcones with electronwithdrawing substituents exhibit higher yields while electrondonating groups led to lower yields. A similar strategy uses a catalytic amount of commercially available iron oxide nanoparticles to promote the 1,3-dipolar cycloaddition reaction [366].

Regioselective [3+2] cycloaddition reaction of chalcones with a sugar azide followed by the in situ oxidation catalyzed by tetrabutylammonium hydrogen sulfate (TBAHS) gave 1,4,5trisubstituted $1 H$-1,2,3-triazoles in good yields (Scheme 43) [367].

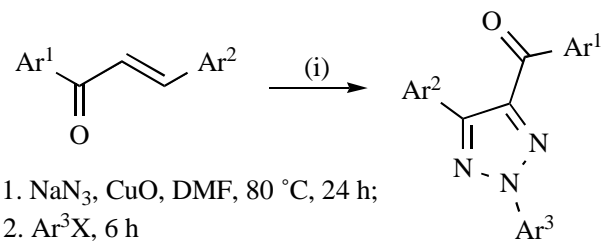

$\mathrm{Ar}^{1}=\mathrm{Ph}, 4-\mathrm{ClC}_{6} \mathrm{H}_{4}, 4-\mathrm{BrC}_{6} \mathrm{H}_{4}, 4-\mathrm{MeOC}_{6} \mathrm{H}_{4}, 4-\mathrm{NO}_{2} \mathrm{C}_{6} \mathrm{H}_{4}$

$\mathrm{Ar}^{2}=\mathrm{Ph}, 4-\mathrm{ClC}_{6} \mathrm{H}_{4}, 4-\mathrm{FC}_{6} \mathrm{H}_{4}, 4-\mathrm{MeC}_{6} \mathrm{H}_{4}, 3,4-\mathrm{diMeC}_{6} \mathrm{H}_{3}$,

$4-\mathrm{MeOC}_{6} \mathrm{H}_{4}, 4-\mathrm{NO}_{2} \mathrm{C}_{6} \mathrm{H}_{4}$

$\mathrm{Ar}^{3} \mathrm{X}=2-\mathrm{NO}_{2} \mathrm{C}_{6} \mathrm{H}_{4} \mathrm{~F}, 2,4-\mathrm{diNO}_{2} \mathrm{C}_{6} \mathrm{H}_{3} \mathrm{Cl}, 2,5-\mathrm{diFC}_{6} \mathrm{H}_{3} \mathrm{NO}_{2}$, 3,4-diFC ${ }_{6} \mathrm{H}_{3} \mathrm{NO}_{2}$

Scheme 42. CuO-promoted one-pot three-component oxidative cycloaddition reaction of chalcones with sodium azide. 
Katritzky et al. reported a novel approach for the synthesis of substituted 1,2,4-triazoles involving the reaction of chalcones with bis(1H-1,2,4-triazolyl) sulfoxide to give thiazolo[3,2-b]1,2,4triazoles in moderate yields (Scheme 44) [368].

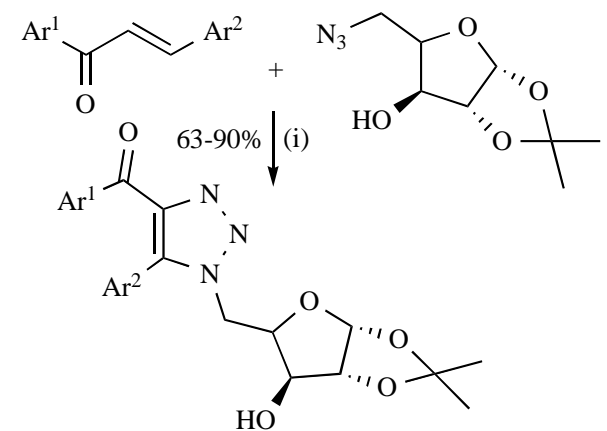

(i) TBAHS, DMF, $100{ }^{\circ} \mathrm{C}, 24 \mathrm{~h}$

$\mathrm{Ar}^{1}=\mathrm{Ph}, 4-\mathrm{ClC}_{6} \mathrm{H}_{4}, 4-\mathrm{FC}_{6} \mathrm{H}_{4}$

$\mathrm{Ar}^{2}=\mathrm{Ph}, 4-\mathrm{BrC}_{6} \mathrm{H}_{4}, 4-\mathrm{ClC}_{6} \mathrm{H}_{4}, 3-\mathrm{NO}_{2} \mathrm{C}_{6} \mathrm{H}_{4}$, 2-naphthyl

Scheme 43. Regioselective synthesis of 1,4,5-trisubstituted $1 \mathrm{H}-1,2,3-$ triazoles by the reaction of chalcones with a sugar azide.

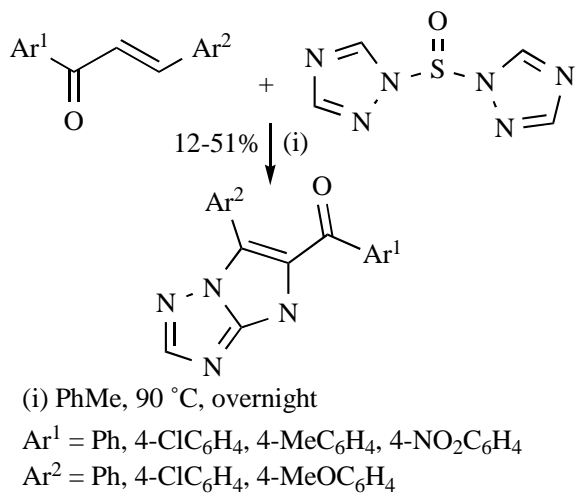

Scheme 44. Synthesis of thiazolo[3,2-b]1,2,4-triazoles.

Tetrazoles are known to possess hypotensive, antifungal, antimicrobial, antiviral, cytostatic and other biological activities [369]. They are also successfully used as components of materials for medical purposes, including components of filter materials for dialysis and ultrafiltration, disease diagnosis and cosmetics [369].

There is no methodology reported for the direct transformation of chalcones to tetrazoles. However, tetrazoles can be synthesized from chalcone-type compounds via pyrazole intermediates, through the reaction with hydrazines [273]. The reaction of chalcones with hydrazine hydrate in acetic acid afforded the intermediate 4,5dihydropyrazolylethanones. These intermediates react with arylhydrazines in ethanol to give the corresponding Schiff bases which heated with acetic anhydride afforded the target tetrazole derivative (Scheme 45).

\subsection{6-Membered Nitrogen Heterocycles}

\subsubsection{Transformation of Chalcones to Pyridines}

In the last recent years, several substituted pyridines claimed attention due to their numerous biological and pharmacological potentials [370]. They can exhibit antibacterial [371-373], antimicrobial [374], antitumor [375, 376] and antiviral [377-379] activities, among others.

The pyridine heterocycles can easily be obtained by condensation of chalcones with 1,3-binucleophiles containing a $\mathrm{CH}$-acidic nucleophilic center, but in the last years there are examples with only malononitrile $[85,86,93,97,118,370,380-382]$. The reaction is usually carried out in ethanol in the presence of ammonium acetate. This approach has been extensively used for the preparation of a wide range of pyridines and was improved through a solvent-free reaction under microwave irradiation $[383,384]$ and even in a solid supported synthesis (Scheme 46) [384, 385]. Some bispyridines have also been prepared using ammonium acetate in ethanol starting from bischalcones and malononitrile [294].

Annelated (dihydropyridines, tetrahydroquinolines, naphthyridines) and substituted pyridines can be synthesized in moderate to good yields (31-70\%) in a consecutive one-pot, four-component process by a coupling-isomerization-enamine addition-cyclocondensation sequence of an electron-poor (hetero)aryl halide, a terminal propargyl alcohol, an enamine, and ammonium chloride or benzylamine (Scheme 47) [386].

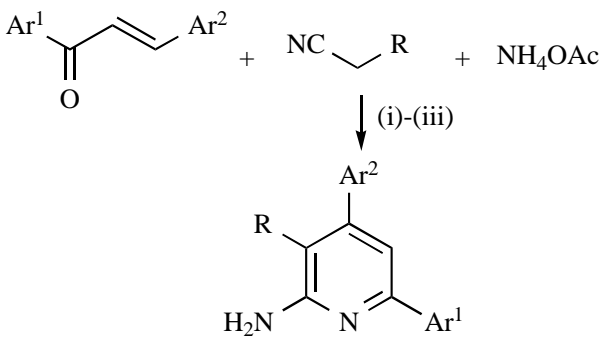

(i) $\mathrm{R}=\mathrm{CN}$, MW, 3.1-4.2 min, montmorillonite clay $\mathrm{K}-10,76-84 \%$

(ii) $\mathrm{R}=\mathrm{CN}, \mathrm{MW}, 4.2-5.1 \mathrm{~min}$, neutral $\mathrm{Al}_{2} \mathrm{O}_{3}, 74-83 \%$

(iii) $\mathrm{R}=\mathrm{CO}_{2} \mathrm{Et}$, MW, 7-9 min, neutral $\mathrm{Al}_{2} \mathrm{O}_{3}, 80-88 \%$

$\mathrm{Ar}^{1}=\mathrm{Ph}, 4-\mathrm{BrC}_{6} \mathrm{H}_{4}$, 3,4-diMeC ${ }_{6} \mathrm{H}_{3}, 4-\mathrm{MeOC}_{6} \mathrm{H}_{4}$ $\mathrm{Ar}^{2}=\mathrm{Ph}, 4-\mathrm{MeOC}_{6} \mathrm{H}_{4}, 3$,4-diMeC $6 \mathrm{H}_{3}$, 2-furyl, 3-indolyl,

benzo[1,3]dioxol-5-yl

Scheme 46. Solvent-free, solid supported synthesis of 4,6-disubstituted 2aminopyridines, under microwave irradiation.

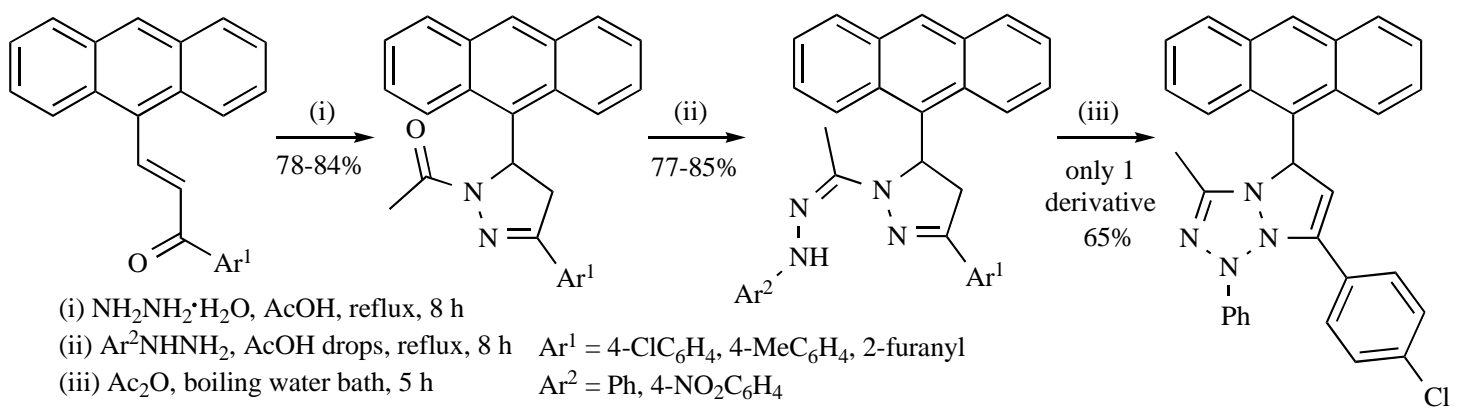

Scheme 45. Multi-step synthesis of 5-(anthracen-9-yl)-7-(4-chlorophenyl)-3-methyl-1-phenyl-1,5-dihydropyrazolo[1,2-a]tetrazole. 


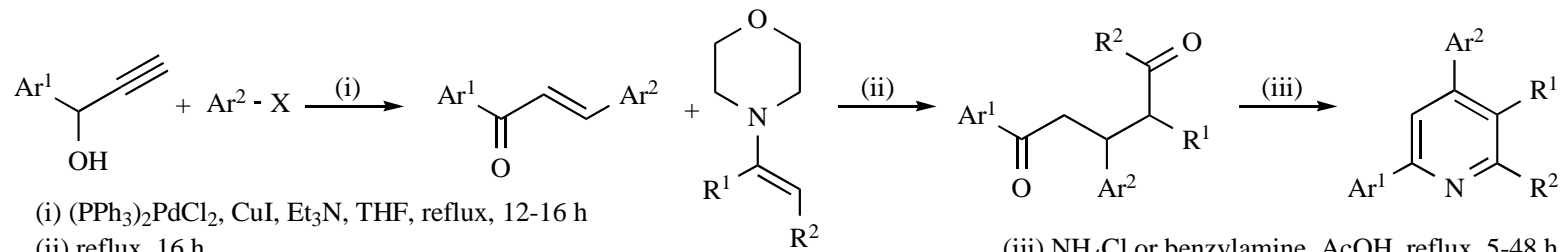
(ii) reflux, $16 \mathrm{~h}$ $\mathrm{R}^{2}$

$\mathrm{Ar}^{1}=4-\mathrm{CF}_{3} \mathrm{C}_{6} \mathrm{H}_{4}, 4-\mathrm{CNC}_{6} \mathrm{H}_{4}, 4-\mathrm{CO}_{2} \mathrm{EtC}_{6} \mathrm{H}_{4}, 2$-pyridyl, 2 pyrimidyl; $\mathrm{Ar}^{2}=\mathrm{Ph}, 4-\mathrm{MeOC}_{6} \mathrm{H}_{4}$

$\mathrm{R}^{1}, \mathrm{R}^{2}=-\left(\mathrm{CH}_{2}\right)_{3}^{-} ;-\left(\mathrm{CH}_{2}\right)_{4}^{-} ;-\left(\mathrm{CH}_{2}\right)_{2}-\mathrm{N}\left(\mathrm{CO}_{2} \mathrm{Et}\right)-\mathrm{CH}_{2^{-}} ; \mathrm{R}^{1}=\mathrm{Ph}, \mathrm{R}^{2}=\mathrm{H} ; \mathrm{R}^{1}=4-\mathrm{MeOC}_{6} \mathrm{H}_{4}, \mathrm{R}^{2}=\mathrm{H} ; \mathrm{R}^{1}=2$-thienyl, $\mathrm{R}^{2}=\mathrm{H}$

Scheme 47. One-pot synthesis of annelated and substituted pyridines.

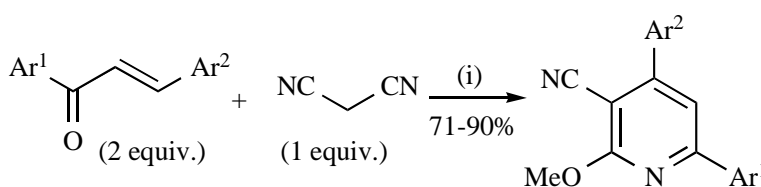

(i) $\mathrm{K}_{2} \mathrm{CO}_{3}, \mathrm{MeOH}, \mathrm{MW}+$ ultrasound, 2-6 min

$\mathrm{Ar}^{1}=\mathrm{Ph}, 4-\mathrm{ClC}_{6} \mathrm{H}_{4}, 4-\mathrm{MeC}_{6} \mathrm{H}_{4}, 4-\mathrm{MeOC}_{6} \mathrm{H}_{4}$

$\mathrm{Ar}^{2}=\mathrm{Ph}, 3-\mathrm{BrC}_{6} \mathrm{H}_{4}, 4-\mathrm{FC}_{6} \mathrm{H}_{4}, 4-\mathrm{MeC}_{6} \mathrm{H}_{4}, 4-\mathrm{MeOC}_{6} \mathrm{H}_{4}$,

4- $\mathrm{CHMe}_{2} \mathrm{C}_{6} \mathrm{H}_{4}, 3,4-\left(\mathrm{O}-\mathrm{CH}_{2}-\mathrm{O}\right) \mathrm{C}_{6} \mathrm{H}_{3}, 3,4,5$-triMeOC $6 \mathrm{H}_{2}$

Scheme 48. $\mathrm{K}_{2} \mathrm{CO}_{3}$-mediated multi-component tandem reaction of chalcone, malononitrile and methanol under combined microwave and ultrasound irradiation.

Feng and co-workers reported the $\mathrm{K}_{2} \mathrm{CO}_{3}$-promoted tandem reaction of malononitrile with chalcones using methanol as nucleophilic agent under combined microwave and ultrasound irradiation to obtain polysubstituted pyridines in good yields (Scheme 48) [387].

One-pot multicomponent reactions of chalcones, 3cyanoacetylindoles and ammonium acetate provided 2-(indol-3yl)pyridine derivatives in good yields, under classical heating conditions [388] and microwave irradiation (Scheme 49) [388-390], while 4,6-diaryl-3-aminoisoxazolo[3,4-b]pyridines resulted from the one-pot reaction of chalcones, malononitrile, and hydroxylamine [391].

The multicomponent reaction of chalcones with pyridinium salts and ammonium acetate was explored to synthesize dihydroxylated 2,4,6-triphenylpyridines as anticancer agents (Scheme 50) [392]. Other pyridine derivatives arise from the reaction of 4hydroxycoumarin-derived chalcones with phenacyl pyridinium bromide and ammonium acetate [393] or by the reaction of thienyl/ furyl-based chalcones with 1-(2-oxo-2-thienyethyl)pyridinium iodides in the presence of ammonium acetate in methanol [375].

Katritzky et al. studied the synthesis of 2-alkylamino-4,6diarylpyridines using solid-phase-bound chalcones [394]. Thus, secondary amines were treated with a solution of $\alpha$-(benzotriazol-1yl)acetonitrile in 2-methoxyethanol and the intermediate formed reacted with the resin-bound chalcones to afford the target 2alkylaminopyridines (Scheme 51).

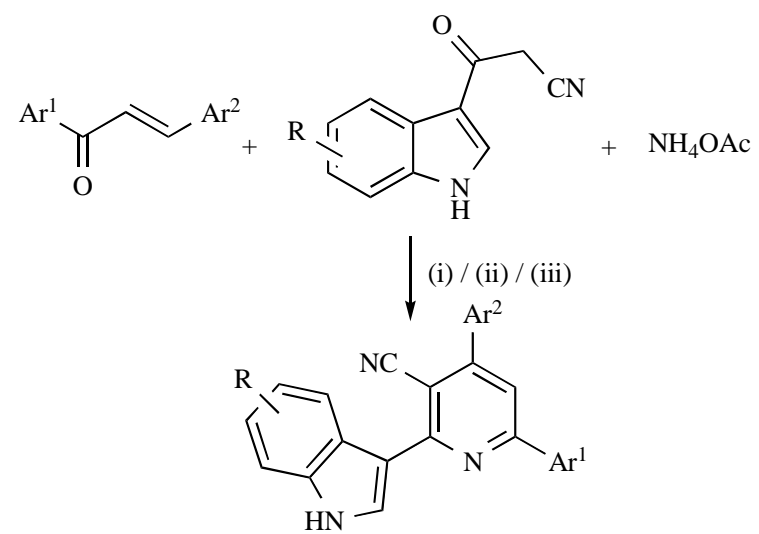

(i) Classical conditions: AcOH:glycol (1:2), reflux, 5 h, 69-76\% MW: AcOH:glycol (1:2), MW, 12-15 min, 75-85\%

(ii) AcOH:glycol (1:2), MW, 10-12 min, 70-87\%

(iii) AcOH:glycol (1:2), MW, 8-12 min, 74-86\%

Scheme 49. Synthesis of 2-(indol-3-yl)pyridines via a one-pot threecomponent reaction of chalcones, 3-cyanoacetylindoles and ammonium acetate.

The reaction of chalcones with aminoazoles is a useful and straightforward method to synthesize fused pyridines. Some reports exploited the reaction of chalcones with 5-amino-1-phenylpyrazoles to synthesize $1 H$-pyrazolo[3,4-b]pyridines in good yields. The reactions were carried out in refluxing DMF [395] or under microwave assisted conditions (Scheme 52) [396]. Other diversely fused pyridines are attained from the reaction of chalcones with several heterocyclic amines [397]. KF/alumina-catalyzed reaction of chalcones with 2,6-diamino-4-hydroxylpyrimidine is conditions-controlled: in an air atmosphere 5,7-diarylpyrido[2,3- $d]$ pyrimidines are isolated, while under dry nitrogen, the unaromatized intermediates dihydropyrido[2,3- $d$ ]pyrimidines are obtained (Scheme 53) [398].

Chalcone-type compounds with different moieties represent a useful starting material for the synthesis of functionalized pyridines. This feature of chalcone-type compounds was explored by Radwan and co-workers in the reaction of 2-chalconylpyrroles with malononitrile either in sodium ethoxide/ethanol or sodium methoxide/methanol to obtain the corresponding 2-alkoxycyanopyridines bearing a pyrrole moiety at C-6 (Scheme 54) [120].

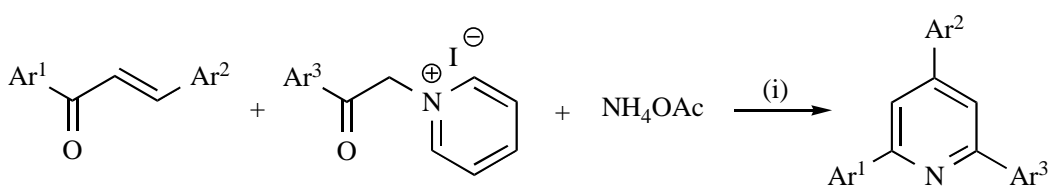

(i) $\mathrm{AcOH}, 90-100{ }^{\circ} \mathrm{C} 12-24 \mathrm{~h}, 20-97 \%$

$$
\mathrm{Ar}^{1}, \mathrm{Ar}^{2}, \mathrm{Ar}^{3}=\mathrm{Ph}, \mathrm{OHC}_{6} \mathrm{H}_{4}
$$

Scheme 50. Synthesis of dihydroxylated 2,4,6-triphenylpyridines through a one-pot three-component reaction of chalcones, pyridinium salts and ammonium acetate. 


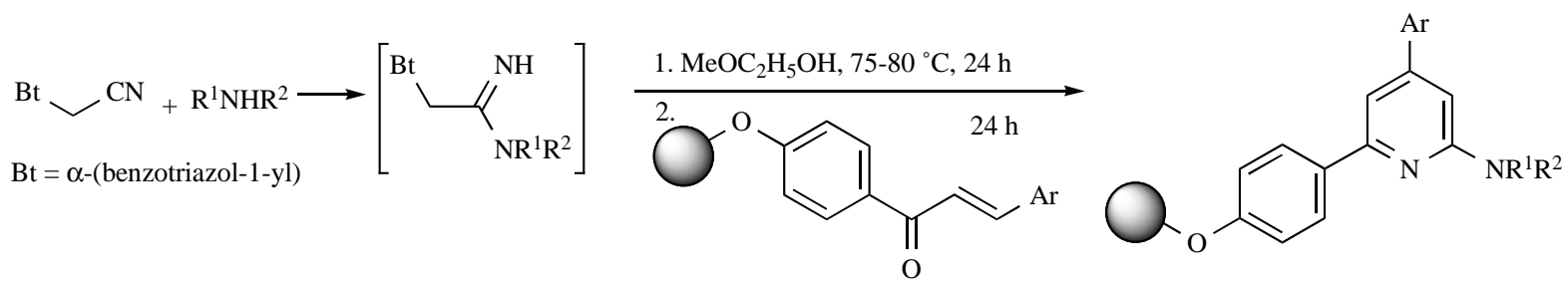

$\mathrm{R}^{1}, \mathrm{R}^{2}=-\left(\mathrm{CH}_{2}\right)_{4}-;-\left(\mathrm{CH}_{2}\right)_{2}-\mathrm{O}-\left(\mathrm{CH}_{2}\right)_{2}-;-\mathrm{CH}_{2}\left(o-\mathrm{C}_{6} \mathrm{H}_{4}\right) \mathrm{CH}_{2} \mathrm{CH}_{2}-;-\left(\mathrm{CH}_{2}\right)_{3} \mathrm{CH}\left(\mathrm{CO}_{2} \mathrm{H}\right)-; \mathrm{CH}_{2} \mathrm{CH}=\mathrm{CH}_{2}, \mathrm{H} ; \mathrm{CH}_{2} \mathrm{CH}\left(\mathrm{CH}_{3}\right)_{2}, \mathrm{H}$; cyclo- $\mathrm{C}_{5} \mathrm{H}_{9}, \mathrm{H} ; \mathrm{CH}\left(\mathrm{CH}_{3}\right) \mathrm{C}_{2} \mathrm{H}_{5}, \mathrm{H} ; \mathrm{CH}_{2} \mathrm{C}_{6} \mathrm{H}_{5}, \mathrm{H} ; \mathrm{CH}_{2} \mathrm{CH}_{2} \mathrm{CO}_{2} \mathrm{H}, \mathrm{H}$ $\mathrm{Ar}=\mathrm{Ph}, 4-\mathrm{MeC}_{6} \mathrm{H}_{4}, 4-\mathrm{MeOC}_{6} \mathrm{H}_{5}$

Scheme 51. One-pot synthesis of 2-alkylamino-4,6-diarylpyridines using solid-phase-bound chalcones.<smiles>[R]c1cc(N)n(-c2ccc([AlH2])c([AlH2])c2)n1</smiles>

(i) $\mathrm{R}=\mathrm{H}$, DMF, reflux, $10 \mathrm{~h}, 52-68 \%$

(ii) $\mathrm{R}=\mathrm{Me}, \mathrm{ZnCl}_{2}$, glycol, $\mathrm{MW}, 8-12 \mathrm{~min}, 85-92 \%$

$\mathrm{Ar}^{1}=2-\mathrm{ClC}_{6} \mathrm{H}_{4}, 2,4-\mathrm{diClC}_{6} \mathrm{H}_{3}, 4-\mathrm{FC}_{6} \mathrm{H}_{4}, 4-\mathrm{MeC}_{6} \mathrm{H}_{4}, 2-\mathrm{MeOC}_{6} \mathrm{H}_{4}$,

$4-\mathrm{MeOC}_{6} \mathrm{H}_{4}$

$\mathrm{Ar}^{2}=4-\mathrm{BrC}_{6} \mathrm{H}_{4}, 4-\mathrm{ClC}_{6} \mathrm{H}_{4}, 3,4-\mathrm{diClC}_{6} \mathrm{H}_{3}, 4-\mathrm{FC}_{6} \mathrm{H}_{4}, 4-\mathrm{MeOC}_{6} \mathrm{H}_{4}, 3-$

$\mathrm{NO}_{2} \mathrm{C}_{6} \mathrm{H}_{4}$

Scheme 52. Synthesis of $1 H$-pyrazolo[3,4-b]pyridines through the reaction of chalcones with 5-amino-1-phenylpyrazoles.<smiles>Nc1cc(O)nc(N)n1</smiles>

(i) $\mathrm{KF} / \mathrm{Al}_{2} \mathrm{O}_{3}$, EtOH, $80{ }^{\circ} \mathrm{C}, 8-12 \mathrm{~h}$

(ii) $\mathrm{KF} / \mathrm{Al}_{2} \mathrm{O}_{3}, \mathrm{EtOH}, \mathrm{N}_{2}, 80{ }^{\circ} \mathrm{C}, 40-60 \mathrm{~min}$

$\mathrm{Ar}^{1}=\mathrm{Ph}, 4-\mathrm{BrC}_{6} \mathrm{H}_{4}, 2-\mathrm{ClC}_{6} \mathrm{H}_{4}, 4-\mathrm{ClC}_{6} \mathrm{H}_{4}, 4-\mathrm{FC}_{6} \mathrm{H}_{4}, 4-\mathrm{MeOC}_{6} \mathrm{H}_{4}$

$\mathrm{Ar}^{2}=\mathrm{Ph}, 2-\mathrm{ClC}_{6} \mathrm{H}_{4}, 3-\mathrm{ClC}_{6} \mathrm{H}_{4}, 4-\mathrm{ClC}_{6} \mathrm{H}_{4}, 3-\mathrm{MeC}_{6} \mathrm{H}_{4}$,

4- $\mathrm{MeOC}_{6} \mathrm{H}_{4}, 3-\mathrm{NO}_{2} \mathrm{C}_{6} \mathrm{H}_{4}, 2$-thiophenyl

Scheme 53. Synthesis of pyrido[2,3-d]pyrimidine derivatives via reaction of chalcones with 2,6-diamino-4-hydroxylpyrimidine.

Trilleras et al. reported a tandem Claisen-Schmidt condensation-Michael addition reaction of 4-chalconylpyrazoles with acetophenones, followed by the reaction of the formed adducts with $\mathrm{NH}_{4} \mathrm{OAc}$, under solvent-free conditions and microwave irradiation, to obtain 2,6-diaryl-4-pyrazolylpyridines (Scheme 55) [399].

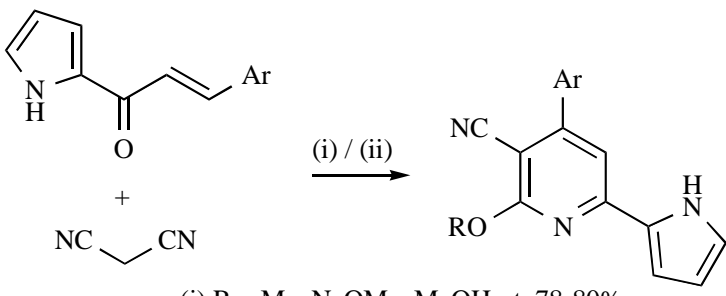

(i) $\mathrm{R}=\mathrm{Me}, \mathrm{NaOMe}, \mathrm{MeOH}, \mathrm{rt}, 78-80 \%$

(ii) $\mathrm{R}=\mathrm{Et}, \mathrm{NaOEt}, \mathrm{EtOH}, \mathrm{rt}, 81-83 \%$

$\mathrm{Ar}=5$-Me-2-furanyl, 4- $\mathrm{ClC}_{6} \mathrm{H}_{4}$

Scheme 54. Synthesis of 2-alkoxycyanopyridines.

The reaction of benzodiazepine-based chalcones with several cyanoacetamide derivatives carried out in ethanol with a catalytic amount of piperidine afforded a wide range of 1,2,5,6-tetrahydro-2oxopyridine-3-carbonitriles [129].

\subsubsection{Transformation of Chalcones to Pyrimidines}

Pyrimidines are widely spread in a large variety of natural compounds as well as in several interesting nucleoside and nonnucleoside compounds. Being a building block of DNA and RNA, pyrimidines have been shown many interesting biological effects namely, antimicrobial [85, 400, 401], antitubercular [402], antitumor $[403,404]$ activities and as selective $\mathrm{A}_{3}$ adenosine receptor antagonists [405].

The most common method towards the synthesis of 2,6disubstituted pyrimidines is the treatment of chalcones with urea and its analogues - thiourea, guanidine and amidines. The most common catalysts for this kind of heterocyclizations are $\mathrm{NaOH}$ [122, 227, 273, 406-413] or $\mathrm{KOH}[86,89,106,137,277,278]$, sodium ethoxide [414, 415], $\mathrm{NaH}$ [416] and the gentler $\mathrm{NaOAc}$ [116]. This reaction can also be done in the absence of catalyst [130] or solid supports [394] with good results. Using concentrated hydrochloric acid as cyclizing agent, the condensation of chalcones with urea, thiourea and guanidine provided also 2-hydroxy-, 2-thioand 2-aminopyrimidines, respectively [417, 418]. Other examples of 2-aminopyrimidines can be achieved through the condensation of chalcones with guanidine hydrochloride in the presence of $\mathrm{NaH}$ in<smiles>CC#CC1CCCCC1</smiles>

(i) $\mathrm{NaOH}$, EtOH, 2.5 h, rt. (ii) $\mathrm{NH}_{4} \mathrm{OAc}$, MW, 2-3 min, 60-90\%

$\mathrm{Ph}$<smiles>NN</smiles><smiles>CC(C)=C(C(C)Cl)C(CC(=O)[Al])CC(=O)[AlH2]</smiles>

$\mathrm{Ar}=\mathrm{Ph}, 4-\mathrm{BrC}_{6} \mathrm{H}_{4}, 4-\mathrm{ClC}_{6} \mathrm{H}_{4}, 4-\mathrm{FC}_{6} \mathrm{H}_{4}, 4-\mathrm{MeC}_{6} \mathrm{H}_{4}, 4-\mathrm{MeOC}_{6} \mathrm{H}_{4}, 3,4,5$-triMeOC 6 H $\mathrm{H}_{2}$, 2-thiophenyl<smiles>Cc1nn(-c2ccccc2)c(Cl)c1-c1cc([Al])nc([Al])c1</smiles> 
DMF [419]. Katritzky et al. reported the synthesis of substituted pyrimidines from the reaction of chalcones with amidine hydrochloride 12 in DMSO at $80{ }^{\circ} \mathrm{C}$ (Scheme 56) [420].

A few substituted chalcones reacted with urea and thiourea to afford pyrimidin-2(1H)-ones and pyrimidin-2 $(1 H)$-thiones, respectively $[85,116]$. Functionalized pyrimidines were synthetized through the condensation of coumarin-chalcones with an unusual hydrazine 13 (resulted from the treatment of nalidixic acid ester with guanidine carbonate in DMF) (Scheme 57) [421].

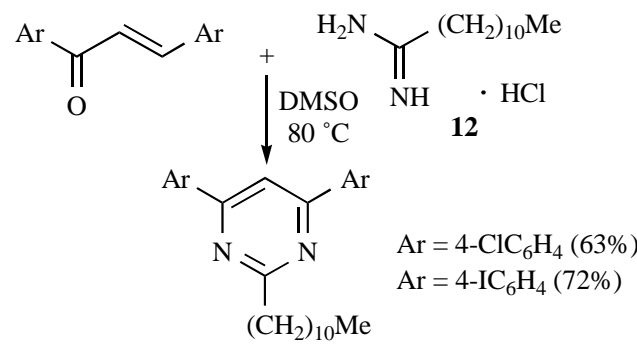

Scheme 56. Condensation of chalcones with amidine hydrochloride $\mathbf{1 2}$ for the synthesis of pyrimidines.
Nagaraj et al. reported the synthesis of a series of bispyrimidines from the reaction of bischalcones with guanidine hydrochloride in aqueous $\mathrm{NaOH}$ in ethanol [422]. More examples arise from the reaction of bischalcones with guanidine hydrochloride in 1,4dioxane [423] and with pyrrolidine-1-carboxamidine hydrochloride or piperidine-1-carboxamidine hydrochloride in sodium isopropoxide / isopropanol (Scheme 58) [424].

The reaction of two equiv of chalcones with a bis-2aminothiazole in refluxing 1,4-dioxane led to the synthesis of bisthiazolo[3,2- $a$ ]pyrimidines in 79-85\% yield (Scheme 59) [425].

High yields of 1,6-dihydropyrimidines result from the reaction of chalcone-type compounds with urea [426], thiourea and guanidine hydrochloride [427], under basic conditions (Scheme 60). A facile microwave assisted synthesis of 4,5-dihydropyrimidin-2amines occurs through the reaction of benzofuran-chalcones and guanidine hydrochloride in the presence of $\mathrm{NaOH}$ [428].

The reaction of 3,4,5,3',4'-pentamethoxychalcone with urea in the presence of concentrated hydrochloric acid in refluxing ethanol provided the corresponding 3,4-dihydropyrimidin-2(1H)-one in $42 \%$ yield. The reaction with substituted thioureas using basic cata-<smiles>CCn1cc(C(=O)NC(=N)N)c(=O)c2ccc(C)nc21</smiles>

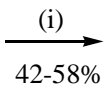

42-58\% 13

(i) piperidine, 1,4-dioxane, reflux, $11 \mathrm{~h}$

$\mathrm{Ar}=\mathrm{Ph}, 3-\mathrm{BrC}_{6} \mathrm{H}_{4}, 4-\mathrm{BrC}_{6} \mathrm{H}_{4}, 4-\mathrm{ClC}_{6} \mathrm{H}_{4}, 2,4-\mathrm{diClC}_{6} \mathrm{H}_{3}, 2,6-\mathrm{diClC}_{6} \mathrm{H}_{3}, 2-\mathrm{OHC}_{6} \mathrm{H}_{4}, 3,4,5-$ triMeOC $_{6} \mathrm{H}_{2}$<smiles>CCn1cc(C(=O)n2c([Al])cc(-c3cc4ccccc4oc3=O)nc2=N)c(=O)c2ccc(C)nc21</smiles>

Scheme 57. Synthesis of functionalized pyrimidines from the reaction of coumarin-chalcones with hydrazine $\mathbf{1 3}$.<smiles>N=C(N)N1CCC(Cl)CC1</smiles>

(i) sodium isopropoxide, isopropanol, reflux, $8 \mathrm{~h}$

$\mathrm{Ar}=\mathrm{Ph}, 4-\mathrm{ClC}_{6} \mathrm{H}_{4}, 4-\mathrm{MeC}_{6} \mathrm{H}_{4}, 3,4-\mathrm{diMeC}_{6} \mathrm{H}_{3}, 4-\mathrm{MeOC}_{6} \mathrm{H}_{4}, 3,4-\mathrm{diMeOC}_{6} \mathrm{H}_{3}$, $3,4,5$-triMeOC $6 \mathrm{H}_{2}, 4-\mathrm{MeSC}_{6} \mathrm{H}_{4}$

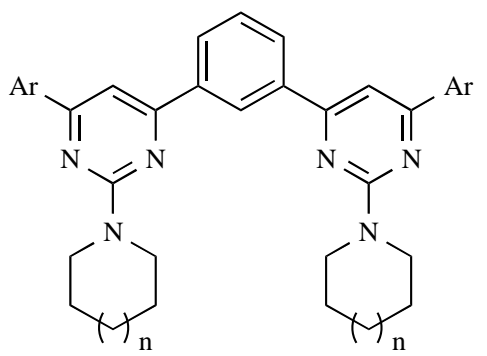

Scheme 58. Synthesis of bispyrimidines by condensation of chalcones with aminoazoles.

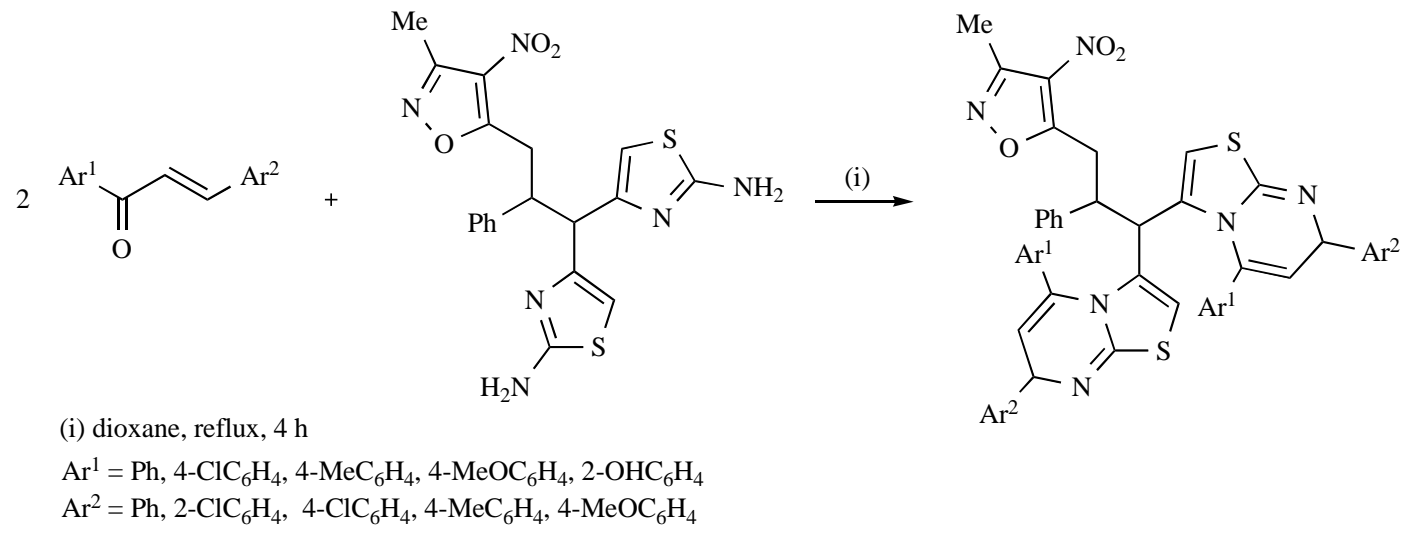

Scheme 59. Synthesis of bisthiazolo[3,2-a]pyrimidines from the reaction of chalcones with bis-2-aminothiazoles. 
lysts afforded 3,4-dihydropyrimidin-2(1H)-thiones, in moderate yields [429]. Other 3,4-dihydropyrimidin-2(1H)-(thi)ones can be synthetized through the condensation of chalcone-type compounds with (thio)urea under the effect of $\mathrm{KOH}$ in refluxing ethanol (Scheme 61) [120, 430]. Using the same conditions, functionalized 5,6-dihydropyrimidin-2(1H)-(thi)ones bearing thiophene [220] and benzofuran [118] moieties were prepared. An ecofriendly approach for the synthesis of 1,2,3-triazolyldihydropyrimidine-2(1H)-thiones involves the reaction of 1,2,3-triazolylchalcones with thiourea in the presence of aqueous $\mathrm{KOH}$ (40 min of reaction with $79-95 \%$ yield). Similar results were obtained using ethanol as solvent (30 min of reaction with $74-95 \%$ yield) [431].

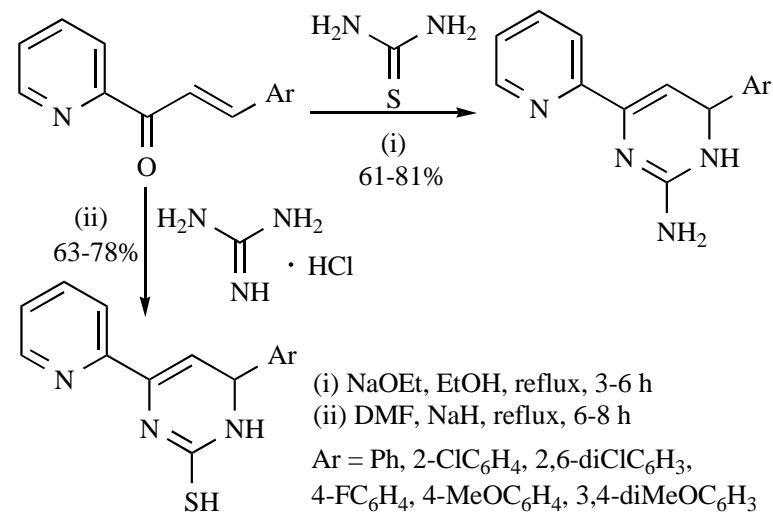

Scheme 60. Synthesis of 1,6-dihydropyrimidines through the reaction of chalcone derivatives with thiourea and guanidine hydrochloride.

A couple of 5,6-dihydropyrimidin-2(1H)-(thi)one arise from the reaction of a chalcone bearing a sulfonamide moiety with (thio)urea [93]. Other examples of 5,6-dihydropyrimidin-2(1H)-(thi)ones were obtained from the reaction of chalcones with (thio)urea in ethanol using $\mathrm{NaOH}$ [115] or piperidine [129] as base.

Cyclocondensation of aminoazoles with chalcones is also a very commonly used approach for the synthesis of pyrimidine derivatives such as dihydro[1,2,3]-triazolo[1,5-a]pyrimidines 14 [432], pyrazolo[1,5-a]pyrimidines $\mathbf{1 5}$ [433, 434], pyridopyrazolopyrimidines 16 [395], isoxazolo[2,3-a]pyrimidines 17 [435] (Scheme 62).

The synthesis of pyrido[2,3- $d]$ pyrimidine derivatives occurred in a two-step or in a one-pot procedure involving the reaction of chalcones, malononitrile, ammonium acetate and phenyl isocyanate, under microwave irradiation on a solid support (montmorillonite clay K-10 or alumina). The one-pot protocol without the solid support and in solvent-free conditions also afforded pyridopyrimidines in excellent yields (Scheme 63) [385].

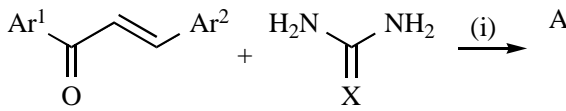

(i) $\mathrm{KOH}, \mathrm{EtOH}$, reflux

$\mathrm{Ar}^{1}=2$-pyrrole, $\mathrm{X}=\mathrm{S}, 10 \mathrm{~h}, 69-77 \%$

$\mathrm{Ar}^{1}=2$-naphthofuran, $\mathrm{X}=\mathrm{O}, 4-6 \mathrm{~h}, 50-56 \%$

Scheme 61. Synthesis of 3,4-dihydropyrimidin-2(1H)-(thi)ones through the reaction of chalcone-type compounds with urea analogs.

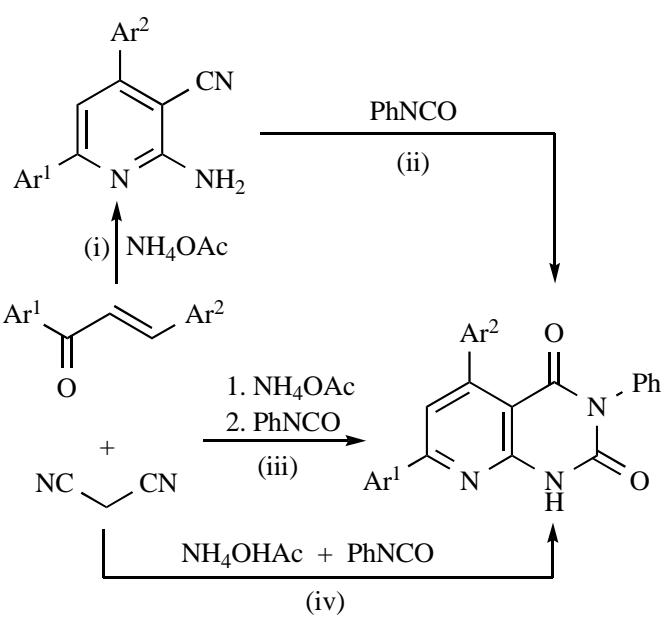

(i) $\mathrm{MW}, 3.1-5.1 \mathrm{~min}$, clay $\mathrm{K}-10(76-84 \%)$ or neutral $\mathrm{Al}_{2} \mathrm{O}_{3}(73-83 \%)$

(ii) $\mathrm{MW}, 4.2-5.9 \mathrm{~min}$, clay $\mathrm{K}-10(77-87 \%)$ or basic $\mathrm{Al}_{2} \mathrm{O}_{3}(73-82 \%)$

(iii) $\mathrm{MW}, 1.5-2.3 \mathrm{~min}$ (after addition of $\mathrm{NH}_{4} \mathrm{OAc}$ ),

clay K-10 (82-89\%)

(iv) $\mathrm{MW}, 2.8-4.3 \mathrm{~min}(93-97 \%)$

$\mathrm{Ar}^{1}=\mathrm{Ph}, 4-\mathrm{BrC}_{6} \mathrm{H}_{4}, 4-\mathrm{MeOC}_{6} \mathrm{H}_{4}$

$\mathrm{Ar}^{2}=4-\mathrm{MeOC}_{6} \mathrm{H}_{4}, 3,4-$ diMeC $_{6} \mathrm{H}_{3}$, 2-furyl, 3-indolyl,

benzo[1,3]dioxol-5-yl

Scheme 63. Ecofriendly synthesis of substituted pyrido[2,3-d]pyrimidine derivatives.<smiles>[R]N=Nc1c(N)nn2c([AlH2])cc([AlH2])nc12</smiles>

15<smiles>[Al]c1cc([Al])n2nc3nc(-c4ccccc4)cc(-c4ccccc4Cl)c3c2n1</smiles>

16

(iv)<smiles>[R]N=Nc1c(N)n[nH]c1N</smiles><smiles>Cc1ccccc1Cl</smiles><smiles>Nc1[nH]nnc1-c1ccccc1</smiles>

$\mathrm{Ph}$<smiles>Cc1cc(N)no1</smiles><smiles>CNc1nnn2c1N=C([Al])CC2[Al]</smiles>

$\mathrm{Ph} 14$ (i) DMF, reflux, $30 \mathrm{~min}$

(ii) $\mathrm{R}=4-(\mathrm{MeOCHN}) \mathrm{C}_{6} \mathrm{H}_{4}$, piperidine, EtOH, reflux, $4 \mathrm{~h}$ (iii) $\mathrm{R}=4-\mathrm{ClC}_{6} \mathrm{H}_{4}, \mathrm{NaOH}$, DMF, reflux, $4-5 \mathrm{~h}$

(iv) $\mathrm{Ar}^{1}=4-\mathrm{BrC}_{6} \mathrm{H}_{4}, \mathrm{Ar}^{2}=4-\mathrm{ClC}_{6} \mathrm{H}_{4}, \mathrm{DMF}$, reflux, $15 \mathrm{~h}$

(v) 1,4-dioxane, reflux, $4 \mathrm{~h}$

Scheme 62. Synthesis of pyrimidine derivatives by condensation of chalcones with aminoazoles. 


\section{CLOSING REMARKS}

In summary, the chemistry of chalcones has attracted the attention of scientists not only for their synthesis but also by their transformations to other biologically important compounds, namely 5- and 6-membered nitrogen heterocyclic compounds. The most recent advances in the synthesis of pyrroles, indoles, isoxazoles, imidazoles, pyrazoles, indazoles, triazoles, tetrazoles, pyridines and pyrimidines from chalcone-type compounds are reviewed. The efforts made to improve the synthetic efficiency rely on the application of easy-to-handle and cheap reagents, alternative heating conditions and greener protocols. Furthermore, the huge library of novel compounds reported since the beginning of the $21^{\text {st }}$ century highlights the importance of this heterocyclic chemistry.

Undoubtedly, chalcones and their analogues continue to be a privileged building block in the synthetic and biological domain being expected further progresses in these fields.

\section{CONFLICT OF INTEREST}

The authors confirm that this article content has no conflict of interest.

\section{ACKNOWLEDGEMENTS}

The authors acknowledge University of Aveiro, Fundação para a Ciência e Tecnologia (FCT, Portugal), European Union, QREN, FEDER and COMPETE for funding the Organic Chemistry Research Unit (project PEst-C/QUI/UI0062/2013; FCOMP-01-0124FEDER-037296).

\section{ABBREVIATIONS}

$\begin{array}{ll}\text { Ac } & =\text { Acetyl } \\ \text { DBU } & 1,8 \text {-diazabicycloundec-7-ene } \\ \text { DDQ } & =2,3 \text {-dichloro-5,6-dicyano-1,4-benzoquinone } \\ \text { DMF } & N, N \text {-dimethylformamide } \\ \text { DMSO } & \text { Dimethylsulfoxide } \\ \text { Et } & =\text { Ethyl } \\ \text { HTIB } & =\text { Hydroxy(tosyloxy)iodobenzene } \\ \text { Me } & =\text { Methyl } \\ \text { MW } & =\text { Microwave } \\ \text { NCS } & =N \text {-chlorosuccinimide } \\ \text { NMO } & =N \text {-methylmorpholine- } N \text {-oxide } \\ \text { OTf } & =\text { Trifluoromethanesulfonate } \\ \text { rt } & =\text { Room temperature } \\ \text { TBAHS } & \text { Tetrabutylammonium hydrogen sulfate } \\ \text { TBD } & =1,5,7 \text {-triazabicyclo[4.4.0]dec-5-ene } \\ \text { THF } & =\text { Tetrahydrofuran } \\ \text { TMS }=\text { Trimethylsilyl }\end{array}$

\section{REFERENCES}

[1] Di Carlo, G.; Mascolo, N.; Izzo, A.A.; Capasso, F. Flavonoids: Old and new aspects of a class of natural therapeutic drugs. Life Sci., 1999, 65, 337-353.

[2] Larsen, M.; Kromann, H.; Kharazmi, A.; Nielsen, S.F. Conformationally restricted anti-plasmodial chalcones. Bioorg. Med. Chem. Lett., 2005, 15, 4858-4861.

[3] Kozlowski, D.; Trouillas, P.; Calliste, C.; Marsal, P.; Lazzaroni, R.; Duroux, J.-L. Density functional theory study of the conformational, electronic, and antioxidant properties of natural chalcones. J. Phys. Chem. A., 2007, 111, 1138-1145.

[4] Yamin, L.J.; Gasull, E.I.; Blanco, S.E.; Ferretti, F.H. Synthesis and structure of 4-X-chalcones. J. Mol. Struct. Theochem., 1998, 428, 167-174.
Bohm, B.A. The Flavonoids - Advances in Research Since. 1986. Harborne, J.B. Ed.; Chapman \& Hall: London, 1994, pp. 387.

[6] Siddiqui, Z.N.; Praveen, S.; Musthafa, T.N.M.; Ahmad, A.; Khan, A.U. Thermal solvent-free synthesis of chromonyl chalcones, pyrazolines and their in vitro antibacterial, antifungal activities. J. Enzyme Inhib. Med. Chem., 2012, 27, 84-91.

[7] Nowakowska, Z. A review of anti-infective and anti-inflammatory chalcones. Eur. J. Med. Chem., 2007, 42, 125-137.

[8] Yang, H.-M.; Shin, H.-R.; Cho, S.-H.; Bang, S.-C.; Song, G.-Y.; Ju, J.-H.; Kim, M.-K.; Lee, S.-H.; Ryu, J.-C.; Kim, Y.; Jung, S.-H. Structural requirement of chalcones for the inhibitory activity of interleukin-5. Bioorg. Med. Chem., 2007, 15, 104-111.

[9] Lee, S.H.; Seo, G.S.; Kim, J.Y.; Jin, X.Y.; Kim, H.-D.; Sohn, D.H. Heme oxygenase 1 mediates anti-inflammatory effects of $2^{\prime}, 4^{\prime}, 6^{\prime}$ tris(methoxymethoxy) chalcone. Eur. J. Pharmacol., 2006, 532, 178-186.

[10] Valla, A.; Valla, B.; Cartier, D.; Le Guillou, R.; Labia, R.; Florent, L.; Charneau, S.; Schrevel, J.; Potier, P. New syntheses and potential antimalarial activities of new 'retinoid-like chalcones'. Eur. J. Med.Chem., 2006, 41 , 142-146.

[11] Domínguez, J.N.; Charris, J.E.; Lobo, G.; Gamboa de Domínguez, N.; Moreno, M.A.M.; Riggione, F.; Sanchez, E.; Olson, J.; Rosenthal, P.J. Synthesis of quinolinyl chalcones and evaluation of their antimalarial activity. Eur. J. Med. Chem., 2001, 36, 555-560.

[12] Liu, M.; Wilairat, P.; Go, M.-L. Antimalarial alkoxylated and hydroxylated chalcones: structure-activity relationship analysis. J. Med. Chem., 2001, 44 4443-4452.

[13] Seo, W.D.; Ryu, Y.B.; Curtis-Long, M.J.; Lee, C.W.; Ryu, H.W.; Jang, K.C. Park, K.H.: Evaluation of anti-pigmentary effect of synthetic sulfonylamino chalcone. Eur. J. Med. Chem., 2010, 45, 2010-2017.

[14] Tomar, V.; Bhattacharjee, G.; Kamaluddin; Ashok, K. Synthesis and antimicrobial evaluation of new chalcones containing piperazine or 2,5dichlorothiophene moiety. Bioorg. Med. Chem., 2007, 17, 5321-5324.

[15] Nowakowska, Z.; Kędzia, B.; Schroeder, G. Synthesis, physicochemical properties and antimicrobial evaluation of new (E)-chalcones. Eur. J. Med. Chem., 2008, 43, 707-713.

[16] Trivedi, J.C.; Bariwal, J.B.; Upadhyay, K.D.; Naliapara, Y.T.; Joshi, S.K.; Pannecouque, C.C.; De Clercq, E.; Shah, A.K. Improved and rapid synthesis of new coumarinyl chalcone derivatives and their antiviral activity. Tetrahedron Lett., 2007, 48, 8472-8474.

[17] Lin, Y.-M.; Zhou, Y.; Flavin, M.T.; Zhou, L.-M.; Nie, W.; Chen, F.-C.: Chalcones and flavonoids as anti-tuberculosis agents. Bioorg. Med. Chem., 2002, 10, 2795-2802

[18] Gacche, R.N.; Dhole, N.A.; Kamble, S.G.; Bandgar, B.P. In-vitro evaluation of selected chalcones for antioxidant activity. J. Enzyme Inhib. Med. Chem., 2008, 23, 28-31.

[19] Ducki, S.; Forrest, R.; Hadfield, J. A.; Kendall, A.; Lawrence, N.J. McGown, A.T.; Rennison, D. Potent antimitotic and cell growth inhibitory properties of substituted chalcones. Bioorg. Med. Chem. Lett., 1998, 8, 10511056.

[20] Boeck, P.; Bandeira Falcão, C.A.; Leal, P.C.; Yunes, R.A.; Filho, V.C.; Torres-Santos, E.C.; Rossi-Bergmann, B. Synthesis of chalcone analogue with increased antileishmanial activity. Bioorg. Med. Chem. Lett., 2006, 14, 1538-1545.

[21] Zhao, L.-M.; Jin, H.-S.; Sun, L.-P.; Piao, H.-R.; Quan, Z.-S. Synthesis and evaluation of antiplatelet activity of trihydroxychalcone derivatives. Bioorg. Med. Chem. Lett., 2005, 15, 5027-5029.

[22] Bonesi, M.; Loizzo, M.R.; Statti, G.A.; Michel, S.; Tillequin, F.; Menichini, F. The synthesis and angiotensin converting enzyme (ACE) inhibitory activity of chalcones and their pyrazole derivatives. Bioorg. Med. Chem. Lett., 2010, 20, 1990-1993.

[23] Dimmock, J.R.; Elias, D.W.; Beazely, M.A.; Kandepu, N.M. Bioactivities of chalcones. Curr. Med. Chem., 1999, 6, 1125-1149.

[24] Sahu, N.K.; Balbhadra, S.S.; Choudhary, J.; Kohli, D.V. Exploring pharmacological significance of chalcone scaffold: a review. Curr. Med. Chem., 2012, 19, 209-225.

[25] Li, R.S.; Kenyon, G.L.; Cohen, F.E.; Chen, X.W.; Gong, B.Q.; Dominguez, J.N.; Davidson, E.; Kurzban, G.; Miller, R.E.; Nuzum, E.O.; Rosenthal, P.J.; McKerrow, J. H. In vitro antimalarial activity of chalcones and their derivatives. J. Med. Chem., 1995, 38, 5031-5037.

[26] Awasthi, S.K.; Mishra, N.; Kumar, B.; Sharma, M.; Bhattacharya, A. Mishra, L.C.; Bhasin, V.K. Potent antimalarial activity of newly synthesized substituted chalcone analogs in vitro. Med. Chem. Res., 2009, 18, 407-420.

[27] Motta, L.F.; Gaudio, A.C.; Takahata, Y.; Quantitative structure-activity relationships of a series of chalcone derivatives (1,3-diphenyl-2-propen-1one) as anti Plasmodium falciparum agents (anti malaria agents). Internet Electron. J. Mol. Des., 2006, 5, 555-569.

[28] Batagin-Neto, A.; Lavarda, F.C.; The correlation between electronic structure and antimalarial activity of alkoxylated and hydroxylated chalcones. Med. Chem. Res., 2014, 23,580-586.

[29] Ávila, H.P.; Smânia, E.F.A.; Monache, F.D.; Júnior, A.S. Structure-activity relationship of antibacterial chalcones. Bioorg. Med. Chem., 2008, 16, 97909794.

[30] Srinivasan, B.; Johnson, T.E.; Lad, R.; Xing, C. Structure-activity relationship studies of chalcone leading to 3-hydroxy-4,3',4',5'-tetramethoxy- 
chalcone and its analogues as potent nuclear factor $\mathrm{KB}$ inhibitors and their anticancer activities. J. Med. Chem., 2009, 52, 7228-7235.

[31] Echeverria, C.; Santibañez, J.F.; Donoso-Tauda, O.; Escobar, C.A.; RamirezTagle, R. Structural antitumoral activity relationships of synthetic chalcones. Int. J. Mol. Sci., 2009, 10, 221-231.

[32] Dhar, D.N. The Chemistry of Chalcones and Related Compounds, Wiley, New York, 1981.

[33] Calvino, V.; Picallo, M.; López-Peinado, A.J.; Martín-Aranda, R.M.; DuránValle, C.J. Ultrasound accelerated Claisen-Schmidt condensation: a green route to chalcones. Appl. Surf. Sci., 2006, 252, 6071-6074.

[34] Al-Masum, M.; Ng, E.; Wai, M.C. Palladium-catalyzed direct cross-coupling of potassium styryltrifluoroborates and benzoyl chlorides - a one-step method for chalcone synthesis. Tetrahedron Lett., 2011, 52, 1008-1010.

[35] Eddarir, S.; Cotelle, N.; Bakkour, Y.; Rolando, C. An efficient synthesis of chalcones based on the Suzuki reaction. Tetrahedron Lett., 2003, 44, 53595363

[36] Kumar, A.; Sharma, S.; Tripathi, V.D.; Srivastava, S. Synthesis of chalcones and flavanones using Julia-Kocienski olefination. Tetrahedron, 2010, 66, 9445-9449.

[37] Desenko, S.M.; Orlov, V.D. Azaheterocycles Based on Aromatic Unsaturated Ketones, Folio: Kharkov, 1998.

[38] Chebanov, V.A.; Desenko, S.M.; Gurley, T.W. Azaheterocycles Based on $\alpha, \beta$-Unsaturated Carbonyls, Springer-Verlag: Berlin Heidelberg, 2008.

[39] Hanessian, S.; McNaughton-Smith, G.; Lombart, H.-G.; Lubell, W. D. Design and synthesis of conformationally constrained amino acids as versatile scaffolds and peptide mimetics. Tetrahedron, 1997, 53, 12789-12854.

[40] Handbook of Porphyrin Science, With Applications to Chemistry, Physics, Materials Science, Engineering, Biology and Medicine, Ed. Kadish K.M., Smith K.M., Guilard R., World Scientific Publishing, Singapore, 2010.

[41] O'Hagan, D.: Pyrrole, pyrrolidine, pyridine, piperidine and tropane alkaloids. Nat. Prod. Rep., 2000, 17, 435-446.

[42] de Laszlo, S.E.; Visco, D.; Agarwal, L.; Chang, L.; Chin, J.; Croft, G.; Forsyth, A.; Fletcher, D.; Frantz, B.; Hacker, C.; Hanlon, W.; Harper, C.; Kostura, M.; Li, B.; Luell, S.; MacCoss, M.; Mantlo, N.; O'Neill, E.A.; Orevillo, C.; Pang, M.; Parsons, J.; Rolando, A.; Sahly, Y.; Sidler, K.; Widmer, W.R.; O'Keefe, S.J. Pyrroles and other heterocycles as inhibitors of P38 kinase. Bioorg. Med. Chem. Lett., 1998, 8, 2689-2694.

[43] Johnson, G.V.W.; Bailey, C.D.C. The p38 MAP kinase signaling pathway in Alzheimer's disease. Exp. Neurol., 2003, 183, 263-268.

[44] Dalrymple, S.A. p38 Mitogen activated protein kinase as a therapeutic target for Alzheimer's disease. J. Mol. Neurosci., 2002, 19, 295-299.

[45] Olson, J.M.; Hallahan, A.R. p38 MAP kinase: a convergence point in cancer therapy. Trends Mol. Med., 2004, 10, 125-129.

[46] Schultz, R.M. Potential of p38 MAP kinase inhibitors in the treatment of cancer. Prog. Drug Res., 2003, 60, 59-92.

[47] Pelaia, G.; Cuda, G.; Vatrella, A.; Gallelli, L.; Caraglia, M.; Marra, M.; Abbruzzese, A.; Caputi, M.; Maselli, R.; Costanzo, F.S.; Marsico, S.A. Mitogen-activated protein kinases and asthma. J. Cell. Physiol., 2005, 202, 642653.

[48] Behr, T.M.; Berova, M.; Doe, C.P.; Ju, H.; Angermann, C.E.; Boehm, J.; Willette, R.N. p38 Mitogen-activated protein kinase inhibitors for the treatment of chronic cardiovascular disease. Curr. Opin. Investig. Drugs., 2003, 4, 1059-1064.

[49] Biava, M.; Porretta, G.C.; Cappelli, A.; Vomero, S.; Manetti, F.; Botta, M.; Sautebin, L.; Rossi, A.; Makovec, F.; Anzini, M. 1,5-Diarylpyrrole-3-acetic acids and esters as novel classes of potent and highly selective cyclooxygenase-2 inhibitors. J. Med. Chem., 2005, 48, 3428-3432.

[50] Khanna, I.K.; Weier, R.M.; Yu, Y.; Collins, P.W.; Miyashiro, J.M.; Koboldt, C.M.; Veenhuizen, A.W.; Currie, J.L.; Seibert, K.; Isakson, P.C. 1,2Diarylpyrroles as potent and selective inhibitors of cyclooxygenase-2. J. Med. Chem., 1997, 40, 1619-1633.

[51] Wilkerson, W.W.; Copeland, R.A.; Covington, M.; Trzaskos, J.M. Antiinflammatory 4,5-diarylpyrroles. 2 . activity as a function of cyclooxygenase-2 inhibition. J. Med. Chem., 1995, 38, 3895-3901.

[52] Wilkerson, W.W.; Galbraith, W.; Gans-Brangs, K.; Grubb, M.; Hewes, W.E.; Jaffee, B.; Kenney, J.P.; Kerr, J.; Wong, N. Antiinflammatory 4,5diarylpyrroles: synthesis and QSAR. J. Med. Chem., 1994, 37, 988-998.

[53] Michaux, C.; Charlier, C.: Structural approach for COX-2 inhibition. MiniRev. Med. Chem. 2004, 4, 603-15.

[54] Garg, R.; Kurup, A.; Mekapati, S.B.; Hansch, C. Cyclooxygenase (COX) inhibitors: a comparative QSAR study. Chem. Rev., 2003, 103, 703-732. Toja, E.G.C.; Barzaghi, F.; Galliani, G. U.S. Patent 4, 885, 307, 1989; Chem. Abstr., 1989, 111, 7219x.

[56] Yavari, I.; Shaabani, A.; Maghsoodlou, M.T. On the reaction between alkyl isocyanides and 3-benzylidene-2,4-pentanedione. A convenient synthetic route to densely functionalized furans. Monatsh. Chem., 1997, 128, 697-700.

[57] Quai, M.; Frattini, S.; Vendrame, U.; Mondoni, M.; Dossena, S.; Cereda, E. 5-hydroxy-2H-pyrrol-2-ones and not 2-aminofurans are the cycloaddition products between alkyl isocyanides and benzyliden-1,3-diketones. Tetrahedron Lett., 2004, 45, 1413-1416.

[58] Adib, M.; Mahdavi, M.; Noghani, M.A.; Bijanzadeh, H. R. Reaction between isocyanides and chalcones: an effcient solvent-free synthesis of 5-hydroxy3,5-diaryl-1,5dihydro-2H-pyrrol-2-ones. Tetrahedron Lett., 2007, 48, 80568059 .
[59] Zheng, D.; Li, S.; Luo, Y.; Wu, J. An efficient route to tetrahydroindeno[2,1$b]$ pyrroles via a base-promoted reaction of $(E)$-2-Alkynylphenylchalcone with 2-isocyanoacetate. Org. Lett., 2011, 13, 6402-6405.

[60] Suresh, R.; Muthusubramanian, S.; Nagaraj, M.; Manickam, G. Indium trichloride catalyzed regioselective synthesis of substituted pyrroles in water. Tetrahedron Lett., 2013, 54, 1779-1784.

[61] Ramón, D.J.; Yus, M. Asymmetric multicomponent reactions (AMCRs): the new frontier. Angew. Chem. Int. Ed., 2005, 44, 1602-1634.

[62] Strübing, D.; Neumann, H.; Hübner, S.; Klaus, S.; Beller, M. Straightforward synthesis of di-, tri- and tetracyclic lactams via catalytic Pauson-Khand and Alder-Ene reactions of MCR products. Tetrahedron., 2005, 61, 11345 11354.

[63] Nair, V.; Sreekumar, V.; Bindu, S.; Suresh, E. Two unprecedented multicomponent reactions involving $N$-heterocyclic carbenes, activated acetylenes, and aldehydes. Org. Lett., 2005, 7, 2297-2300.

[64] Chen, G.; Wu, Y.; Gu, X. Spiro indane-1,3-dione pyrrolizidine compounds synthesized by 1,3-dipolar cyclo-addition reaction. Heterocycl. Commun., 2011, 17, 161-163.

[65] Rajakumar, P.; Raja, S.; Thirunarayanan, A. A facile synthesis of novel pyrrolidine dendrimers by terminal group modification through 1,3-dipolar cycloaddition reaction. Synlett, 2010, 1669-1673.

[66] Moemeni, M.; Arvinnezhad, H.; Samadi, S.; Tajbakhsh, M.; Jadidi, K.; Khavasi, H. R. An efficient multicomponent and stereoselective synthesis of new spiro indeno[1,2- $b]$ quinoxaline-11,2'-pyrrolidine derivatives. J. Heterocycl. Chem., 2012, 49, 190-194.

[67] Liang, Y.; Dong, D.; Lu, Y.; Wang, Y.; Pan, W.; Chai, Y.; Liu, Q. One-pot synthesis of substituted $\Delta 1$-pyrrolines through the Michael addition of nitroalkanes to chalcones and subsequent reductive cyclization in aqueous media. Synthesis., 2006, 3301-3304.

[68] Borovskoy, V.A.; Komykhov, S.A.; Musatov, V.I.; Shishkina, S.V.; Shishkin, O.V.; Desenko, S.M. Unusual reaction of 2-(aminomethyl) benzimidazole with chalcones: synthesis of new aryl-substituted pyrrolines. Collect. Czech. Chem. Commun., 2009, 74, 1403-1410.

[69] Wood, K.; Black, D.S.; Kumar, N. An efficient synthesis of $9 H$-pyrrolo[1,2a] indoles. Tetrahedron Lett., 2009, 50, 574-576.

[70] Rani, P.; Srivastava, V. K.; Kumar, A. Synthesis and antiinflammatory activity of heterocyclic indole derivatives. Eur. J. Med. Chem., 2004, 39 449-452.

[71] Przheval'skii, N.M.; Magedov, I.V.; Drozd, V.N. New derivatives of indole. Synthesis of s-(indolyl-3)diethyl dithiocarbamates. Chem. Heterocycl. Compd., 1997, 33, 1475-1476.

[72] Al-Hiari, Y.M.; Qaisi, A.M.; El-Abadelah, M.M.; Voelter, W. Synthesis and antibacterial activity of some substituted 3-(aryl)- and 3-(heteroaryl)indoles. Monatsh. Chem., 2006, 137, 243-248.

[73] Queiroz, M.-J.R.P.; Abreu, A.S.; Carvalho, M.S.D.; Ferreira, P.M.T.; Nazareth, N.; Nascimento, M.S.-J. Synthesis of new heteroaryl and heteroannulated indoles from dehydrophenylalanines: antitumor evaluation. Bioorg. Med. Chem., 2008, 16, 5584-5589.

[74] Chacón-García, L.; Martínez, R. Synthesis and in vitro cytotoxic activity of pyrrolo[2,3-e]indole derivatives and a dihydrobenzoindole analogue. Eur. $J$. Med. Chem., 2002, 37, 261-266.

[75] Merino, I.; Monge, A.; Font, M.A.; Martínez de Irujo, J.J.; Alberdi, E. Santiago, E.; Prieto, I.; Lasarte, J.J.; Sarobe, P.; Borrás, F. Synthesis and anti-HIV-1 activities of new pyrimido[5,4-b]indoles. Il Farmaco., 1999, 54, 255-264.

[76] Talaz, O.; Gülçin, İ.; Göksu, S.; Saracoglu, N. Antioxidant activity of 5,10dihydroindeno[1,2- $b]$ indoles containing substituents on dihydroindeno part. Bioorg. Med. Chem., 2009, 17, 6583-6589.

[77] Abele, E.; Abele, R.; Dzenitis, O.; Lukevics, E. Indole and isatin oximes: synthesis, reactions, and biological activity. Chem. Heterocycl. Compd., 2003, 39, 3-35.

[78] Wang, B.X.; Liu, W.W.; He, T.; Hu, H.W. Oxidant promoted 1,3-dipolar cycloaddition of pyridinium ylides to chalcones for preparation of 1-benzoyl2-arylindolizines. Chin. J. Chem., 2006, 24, 279-281.

[79] Binder, F.R.D.; Ferber, H.P. US Pat. 4841065, 1989; Chem Abstr., 1985, 103, 196028.

[80] Hansen, J.F.; Strong, S.A. Reaction of vinyl ketoximes with $N$ bromosuccinimide. Synthesis of isoxazoles and 4-bromoisoxazolines. J. Het erocycl. Chem., 1977, 14, 1289-1289.

[81] Habeeb, A.G.; Rao, P.N.P.; Knaus, E.E. Design and synthesis of 4,5diphenyl-4-isoxazolines: novel inhibitors of cyclooxygenase-2 with analgesic and antiinflammatory activity. J. Med. Chem., 2001, 44, 2921-2927.

[82] Archana; Srivastava, V.K.; Chandra, R.; Kumar, A. Synthesis of potential quinazolinonyl pyrazolines and quinazolinyl isoxazolines as anticonvulsant agents. Indian J. Chem., Sect B., 2002, 41, 2371-2375.

[83] Kumbhare, R.M.; Kosurkar, U.B.; Janaki Ramaiah, M.; Dadmal, T.L.; Pushpavalli, S.N.C.V.L.; Pal-Bhadra, M. Synthesis and biological evaluation of novel triazoles and isoxazoles linked 2-phenyl benzothiazole as potential anticancer agents. Bioorg. Med. Chem. Lett., 2012, 22, 5424-5427.

[84] Mamouni, A.; Schmitt, P.; Mansour, M.; Schiavon, M. Abiotic degradation pathways of isoxaben in the environment. Pestic. Sci., 1992, 35, 13-20.

[85] Fathalla, O.A.; Awad, S.M.; Mohamed, M.S. Synthesis of new 2-thiouracil5-sulphonamide derivatives with antibacterial and antifungal activity. Arch. Pharm. Res., 2005, 28, 1205-1212. 
[86] Solankee, A.; Patel, K.; Patel, R. Antimicrobial evaluation of some novel isoxazoles, cyanopyridines and pyrimidinthiones. Indian J. Chem., Sect B., 2013, 52, 671-676.

[87] Solankee, A.; Kapadia, K.; Solankce, P.; Pra-Japati, Y.; Patel, F.; Solarikee, S. Synthesis and characterization of some novel isoxazoles and 1,5benzothiazepines bearing s-triazine nucleus. Indian J. Chem., Sect B., 2008, 47, 473-476.

[88] Solankee, A.; Kapadia, K.; Solankee, P.; Prajapati, Y.; Patel, H.; Solankee, S. Synthesis and studies of some novel s-triazine based aminopyrimidines, isoxazoles and 1,5-benzothiazepines. Indian J. Chem., Sect B., 2007, 46, $1707-1712$

[89] Murthy, Y.L.N.; Nanda, R.; Kumar, K.R.; Swany, G. Synthesis and characterization of a new chromanoisoxazole. Indian J. Chem., Sect B., 2006, 45, 532-534.

[90] Murthy, Y.L.N.; Prabha, R.S.; Shettigar, S. Synthesis, characterisation of new chromanoisoxazoles and investigation of optical power limiting properties. Indian J. Chem., Sect B, 2004, 43, 361-366.

[91] Al-Omran, F.; Abou El-Khair, A. Synthesis of polyfunctionally substituted heteroaromatic compounds via benzotriazolyl chalcones with antimicrobial and antifungal activities. J. Heterocycl. Chem., 2004, 41, 327-333.

[92] Kini, S.G.; Bhat, A.R.; Bhat, R.; Narayanaswamy, N. Synthesis and antimicrobial activity of new 3,5-disubstituted isoxazoles. Indian J. Heterocycl. Chem., 2008, 17, 319-322.

[93] Moustafa, O.S.; Ahmad, R.A. Synthesis and antimicrobial activity of some new cyanopyridines, isoxazoles, pyrazoles, and pyrimidines bearing sulfonamide moiety. Phosphorus Sulfur Silicon Relat. Elem., 2003, 178, 475484.

[94] Vekariya, N.A.; Khunt, M.D.; Parikh, A.R. Synthesis of isoxazoles and quinoxalines as potential anticancer agents. Indian J. Chem., Sect B., 2003, 42, 421-424.

[95] Manna, K.; Agarwal, Y.K.; Srinivasan, K.K. Synthesis and biological evaluation of new benzofuranyl isoxazoles as antitubercular, antibacterial and antifungal agents. Indian J. Heterocycl. Chem., 2008, 18, 87-88.

[96] Panda, S.S.; Chowdary, P.V.R.; Jayashree, B.S. Synthesis, antiinflammatory and antibacterial activity of novel indolyl-isoxazoles. Indian J. Pharm. Sci., 2009, 71, 684-687.

[97] Moustafa, O.S. Synthesis of some new heterocycles of pharmaceutical interest: pyridinyl and isoxazolyl quinoxaline derivatives. J. Chin. Chem. Soc., 2003, 50, 1205-1208.

[98] Sekhar, K.V.G.C.; Sasank, T.V.N.V.T.; Nagesh, H.N.; Suresh, N.; Naidu, K.M.; Suresh, A. Synthesis of 3,5-diarylisoxazoles under solvent-free conditions using iodobenzene diacetate. Chin. Chem. Lett., 2013, 24, 1045-1048.

[99] Abdel-Fattah, A.A.A. Synthesis of substituted alpha,beta-unsaturated ketones, pyrazoles, isoxazoles and 2,4,6-triarylpyrylium chlorophosphates via beta-lithiation of benzotriazolylvinyl ethyl ether. Synthesis., 2005, 245-249.

[100] Reddy, C.S.; Nagaraj, A. Synthesis of novel methylene-bis-isoxazoles as potential fungicidal agents. Heterocycl. Commun., 2008, 14, 289-294.

[101] Kamal, R.; sharma, D.; Wadhwa, D.; Prakash, O. The chemistry of $\alpha, \beta$ ditosyloxy ketones: a new and convenient route to 4,5-diarylisoxazoles from $\alpha, \beta$-chalcone ditosylates. Synlett., 2012, 23, 93-96.

[102] Joseph, M.S.; Totagi, R.S.; Basanagoudar, L.D. Synthesis and antimicrobial activity of indole isoxazolines and isoxazole derivatives. Indian J. Chem. B., 2004, 43, 964-970.

[103] Prakash, E.O.; Rao, J.T. Synthesis and antimicrobial activity of 3-(2',4'dichloro-5'-fluoro)phenyl-5-aryl isoxazoles. Asian J. Chem., 2003, 15, 538540 .

[104] Naik, V.R.; Naik, H.B. Synthesis and antibacterial activity of 2'-hydroxy-3'bromo-5'-ethyl chalcones and 3-(2'-hydroxy-3'-bromo-5'-ethyl phen-1'-yl)5-substituted phenyl-2-isoxazoles. Asian J. Chem., 2000, 12, 305-307.

[105] Akbar, S.; Srinivasan, K. A tandem strategy for the synthesis of $1 \mathrm{H}$ benzo $[g]$ indazoles and naphtho[2,1- $d]$ isoxazoles from $o$-alkynylarene chalcones. Eur. J. Org. Chem., 2013, 1663-1666.

[106] Gautam, N.; Chourasia, O.P. Synthesis, characterization, antimicrobial, insecticidal and anthelmintic screening of some new s-triazine derivatives of pyrazoline, pyrimidine, isoxazoline and isothiazoline moiety. Indian J. Chem. B., 2012, 51, 1400-1410.

[107] Roman, B.I.; De Ryck, T.; Dierickx, L.; Vanhoecke, B.W.A.; Katritzky, A.R.; Bracke, M.; Stevens, C.V. Exploration of the SAR of anti-invasive chalcones: Synthesis and biological evaluation of conformationally restricted analogues. Bioorg. Med. Chem., 2012, 20, 4812-4819.

[108] Parmar, P.J.; Rajput, S.I. Synthesis and characterization of some nitrosubstituted 3,5-diaryl isoxazolines, thioisoxazolines and their derivatives. Asian J. Chem., 2007, 19, 1519-1523.

[109] Thore, S.N. Synthesis and antimicrobial study of triazolo pyrazolines and isoxazoline derivatives. Asian J. Chem., 2005, 17, 2463-2466.

[110] Sudhir, P.; Rajashree, C.; Ashok, B. Synthesis and biological evaluation of Mannich bases of isoxazoline derivatives as novel anti-microbial agents. $E$-J. Chem., 2012, 9, 1760-1772.

[111] Bhat, K.I.; Kumar, R.K.A.; Kumar, A. Synthesis, pharmacological and biological screening of new isoxazolines. Indian J. Heterocycl. Chem., 2011, 21, 163-166.

[112] Sharma, V.; Sharma, K.V. Synthesis and biological activity of some 3,5diarylisoxazoline derivatives: reaction of substituted chalcones with hydroxylamine hydrochloride. E-J. Chem., 2010, 7, 203-209.
[113] Voskiene, A.; Mickevicius, V. Cyclization of chalcones to isoxazole and pyrazole derivatives. Chem. Heterocycl. Compd., 2009, 45, 1485-1488.

[114] Gantla, C.R.; Suresh, Y.; Harikrishana, S.; Shrivastava, S.P. Synthesis and antibacterial activity of some substituted isoxazolines and isothiazolines. Orient. J. Chem., 2009, 25, 153-157.

[115] Abdel-Rahman, A.A.H.; Abdel-Megied, A.E.S.; Hawata, M.A.M.; Kasem, E.R.; Shabaan, M.T. Synthesis and antimicrobial evaluation of some chalcones and their derived pyrazoles, pyrazolines, isoxazolines, and 5,6dihydropyrimidine-2-(1H)-thiones. Monatsh. Chem., 2007, 138, 889-897.

[116] El-Sawy E.R.; Mandour, A.H.; Mahmoud, K.; Islam, IE.-E.; Abo-Salem, H.M. Synthesis, antimicrobial and anti-cancer activities of some new $\mathrm{N}$ ethyl, $N$-benzyl and $N$-benzoyl-3-indolyl heterocycles. Acta Pharm., 2012, 62, 157-179.

[117] Hamada, N.M.M.; Sharshira, E.M. Synthesis and antimicrobial evaluation of some heterocyclic chalcone derivatives. Molecules., 2011, 16, 2304-2312.

[118] El Shehry, M.F.; Swellem, R.H.; Abu-Bakr, S.M.; El-Telbani, E.M. Synthesis and molluscicidal evaluation of some new pyrazole, isoxazole, pyridine, pyrimidine, 1,4-thiazine and 1,3,4-thiadiazine derivatives incorporating benzofuran moiety. Eur. J. Med. Chem., 2010, 45, 4783-4787.

[119] Desai, J.M.; Shah, V.H. Synthesis and biological activity of cyanopyridine, isoxazole and pyrazoline derivatives having thymol moiety. Indian J. Chem. B., 2003, 42, 382-385.

[120] Radwan, M.A.A.; Abbas, E.M.H. Synthesis of some pyridine, thiopyrimidine, and isoxazoline derivatives based on the pyrrole moiety. Monatsh. Chem., 2009, 140, 229-233.

[121] Srinivas, A.; Nagaraj, A.; Reddy, C.S. Synthesis and in vitro study of methylene-bis-tetrahydro[1,3]thiazolo[4,5-c] isoxazoles as potential nematicidal agents. Eur. J. Med. Chem., 2010, 45, 2353-2358.

[122] Bapna, A.; Ojha, S.; Talesara, G.L. Facile synthesis of alkoxyphthalimide derivatized benzimidazole assembled pyrazoles, pyrimidines and isoxazoles, via common intermediate chalcone. Indian J. Chem. B., 2008, 47, 10961107.

[123] Safaei-Ghomi, J.; Ghasemzadeh, M.A. Synthesis of some 3,5-diaryl-2isoxazoline derivatives in ionic liquids media. J. Serb. Chem. Soc., 2012, 77 733-739.

[124] Shakhawat, S.; Devpura, A.; Sing, J.P.; Sharma, P.; Dangi, L.L.; Dulawat, S.S. Microwave assisted solid support synthesis of some 3,5-diaryl- $\Delta^{2}$ isoxazolines as potential antibacterial agents. J. Chem. Biol. Phys. Sci., 2011 1, 1-6.

[125] Jadhav, S.B.; Shastri, R.A.; Gaikwad, K.V.; Gaikwad, S.V. Synthesis and antimicrobial studies of some novel pyrazoline and isoxazoline derivatives. E-J. Chem., 2009, 6, S183-S188.

[126] Agrawal, N.N.; Soni, P.A. Synthesis of pyrazoline and isoxazoline in triethanolamine medium. Indian J. Chem. B., 2004, 43, 2700-2701.

[127] Gajbhiye, J.M.; Jamode, V.S. Synthesis of bis-isoxazolines. Asian J. Chem. 2001, 13, 1664-1666

[128] Maurya, M.; Parhate, V.V.; Deshmukh, M.S.; Rajput, P.R. Synthesis and antimicrobial study of some new chlorosubstituted isoxazolines. Asian J. Chem., 2003, 15, 1184-1186.

[129] El-Azab, I.H. Synthesis of some new benzo[b][1,4]diazepine based heterocycles. J. Heterocycl. Chem., 2013, 50, E178-E188.

[130] Mahadevan, K.M.; Basavaraj, K.M.; Mathias, D.A.P.; Vaidya, V.P. Synthesis of novel naphtho[2,1-b]furo pyrazolyl, isoxazolyl and pyridyl derivatives as potential antimicrobial agents. Indian J. Chem. B., 2005, 44, 789-793.

[131] Badadhe, P.V.; Chavan, N.M.; Mandhane, P.G.; Joshi, R.S.; Nagargoje, D.R.; Gill, C.H. Synthesis and characterization of some novel isoxazolines and pyrazolines as potent antimicrobial agents. Indian J. Chem. B., 2011, 50, 879-884.

[132] Shah, T.; Desai, V. Synthesis and antibacterial studies of some novel isoxazoline derivatives. J. Serb. Chem. Soc., 2007, 72, 443-449.

[133] Hassan, S.Y. Synthesis, antibacterial and antifungal activity of some new pyrazoline and pyrazole derivatives. Molecules., 2013, 18, 2683-2711.

[134] Chavan, R.S.; Khadke, A.P. Synthesis and biological evaluation of novel indolyl isoxazoline derivatives as analgesic and antiinflammatory agents. Asian J. Chem., 2012, 24, 2711-2716.

[135] Mondal, P.; Jana, S.; Balaji, A.; Ramakrishna, R.; Kanthal, L. Synthesis of some new isoxazoline derivatives of chalconised indoline-2-one as a potential analgesic, antibacterial and anthelmimtic agents. J. Young Pharmacists. 2012, 4, 38-41.

[136] Ram, D.R.; Nasir, H.; Gangotri, P.; Talesara, G.L. A convenient synthesis of ethoxyphthalimide derivatized quinazoline assembled isoxazoles and pyrazoles via common intermediate chalcone. Res. J. Chem. Environ., 2010, 14, 27-31.

[137] Solankee, A.; Thakor, I. Synthesis of pyrazolines, isoxazolines and aminopyrimidines as biological potent agents. Indian J. Chem. B., 2006, 45, 517 522.

[138] Nyati, A.; Rao, N.S.; Shrivastav, Y.K.; Verma, B.L. Microwave induced synthesis and antimicrobial activity of some 3-benzimidazolyl-5-aryl-2isoxazolines. Indian J. Heterocycl. Chem., 2006, 15, 295-296.

[139] Solankee, A. Synthesis and characterization of s-triazine based 1,5 benzothiazepines and isoxazoles. J. Indian Chem. Soc., 2010, 87, 993-997.

[140] Mran, M.; Khan, S.A. Synthesis of 3,5-disubstituted isoxazolines as potential antibacterial and antifungal agents. Indian J. Heterocycl. Chem., 2004, 13, 213-216. 
[141] Kansagra, B.P.; Bhatt, H.H.; Parikh, A.R. Synthesis and antimicrobial activity of some isoxazoles and cyanopyridines. Indian J. Heterocycl. Chem., 2002, 12, 61-64

[142] Khunt, R.C.; Datta, N.J.; Bharmal, F.M.; Mankad, G.P.; Parikh, A.R. Synthesis and biological evaluation of cyanopyridine and isozazole derivatives. Indian J. Heterocycl. Chem., 2000, 10, 97-100.

[143] Basawaraj, R.; Ali, A.; Khandre, O.; Sangapure, S.S. Synthesis of some new pyrazolines, isoxazoles and pyrimidines as potential antimicrobial agents. Indian J. Heterocycl. Chem., 2007, 17, 11-14.

[144] Zielinska-Blajet, M.; Kowalczyk, R.; Skarzewski, J. Ring-closure reactions through intramolecular substitution of thiophenoxide by oxygen and nitrogen nucleophiles: simple stereospecific synthesis of 4,5-dihydroisoxazoles and 4,5-dihydropyrazoles. Tetrahedron., 2005, 61, 5235-5240.

[145] Dong, Z.-Q.; Liu, F.-M.; Chen, S.-Q. Synthesis and crystal structure of isoxazoline derivatives bearing a 1,2,4-triazole moiety. Monatsh. Chem., 2012, 143, 1523-1528.

[146] Shang, Y.; Ren, L.; Wu, J.: Novel method for soluble-polymer-supported synthesis of 3,4,5-trisubstituted isoxazoles. Synth. Commun., 2008, 38, 583-594.

[147] Mistry, B.D.; Desai, K.R.; Rana, P.B. Conventional and microwave induced synthesis of various pyrimidine and isoxazole derivatives from 1-\{4'-(4', methylpiperazinyl) diazenylphenyl \}-3-(substitutedphenyl)-prop-2-en-1-one and studies of their antimicrobial activity. Indian J. Chem. B., 2011, 50, 627633.

[148] Upadhyay, A.; Gopal, M.; Srivastava, C.; Pandey, N.D. Isoxazole derivatives as a potential insecticide for managing Callosobruchus chinensis. J. Pestic. Sci., 2010, 35, 464-469.

[149] Sharma, S.; Pathak, V.N.; Madan, H.; Sharma, A. Synthesis of new 3-(4fluoronaphthyl)-5-(aryl)-2-isoxazolines and their antimicrobial and spermicidal activity. Indian J. Heterocycl. Chem., 2010, 19, 337-340.

[150] Shrimali, K.; Ameta, R.; Punjabi, P.B.; Ameta, S.C. Efficient heterocyclizations leading to substituted isoxazoles and pyrimidines and their biological activity. Indian J. Heterocycl. Chem., 2010, 19, 257-260.

[151] Vyas, R.; Swarnkar, N.; Sancheti, A.; Verdia, J.; Punjabi, P.B. Heterocyclization of some chalcones to isoxazoles, pyrazoles and pyrimidine nuclei under microwave irradiation and their biological profile. J. Indian Chem. Soc., 2008, $85,1217-1226$

[152] Gahlot, U.S.; Rao, S.S.; Jhala, Y.S.; Dulawat, S.S.; Verma, B.L.: Microwave assisted synthesis and antibacterial activity of some new 3,5-diaryl-2isoxazolines. Indian J. Heterocycl. Chem., 2003, 13, 111-114.

[153] Kidwai, M.; Kukreja, S.; Thakur, R. $\mathrm{K}_{2} \mathrm{CO}_{3}$-Mediated regioselective synthesis of isoxazoles and pyrazolines. Lett. Org. Chem., 2006, 3, 135-139.

[154] Balalaie, S.; Sharifi, A.; Ahangarian, B. Solid phase synthesis of isoxazole and pyrazole derivatives under microwave irradiation. Indian J. Heterocycl. Chem., 2000, 10, 149-150.

[155] Irlapati, N.R.; Baldwin, J.E.; Adlington, R.M.; Pritchard, G.J.; Cowley, A.R. Regio- and stereospecific [3+2] cycloaddition of an unusual nitrone derived from a $N$-hydroxy-2-pyridone withmedium ring enones. Tetrahedron., $\mathbf{2 0 0 5}, 61,1773-1784$

[156] Acharjee, N.; Banerji, A.; Prange, T. DFT study of 1,3-dipolar cycloadditions of $\mathrm{C}, \mathrm{N}$-disubstituted aldonitrones to chalcones evidenced by NMR and X-ray analysis. Monatsh Chem., 2010, 141, 1213-1221.

[157] Iannazzo, D.; Brunaccini, E.; Giofrè, S.V.; Piperno, A.; Romeo, G.; Ronsisvalle, S.; Chiacchio, M.A.; Lanza, G.; Chiacchio, U. Competitive formation of $\beta$-enaminones and 3 -amino- $2(5 H)$-furanones from the isoxazolidine system: a combined synthetic and quantum chemical study. Eur. J. Org. Chem., 2010, 5897-5905.

[158] Piotrowska, D.G.; Cieslak, M.; Krolewska, K.; Wroblewski, A.E. Design, synthesis and cytotoxicity of a new series of isoxazolidines derived from substituted chalcones. Eur. J. Med. Chem., 2011, 46, 1382-1389.

[159] Atia, A.J.K. Synthesis and antibacterial activities of new metronidazole and imidazole derivatives. Molecules., 2009, 14, 2431-2446.

[160] Liu, L.-X.; Wang, X.-Q.; Yan, J.-M.; Li, Y.; Sun, C.-J.; Chen, W.; Zhou, B.; Zhang, H.-B.; Yang, X.-D.: Synthesis and antitumor activities of novel dibenzo[b,d]furan-imidazole hybrid compounds. Eur. J. Med. Chem., 2013, 66, 423-437.

[161] Wang, X.-Q.; Liu, L.-X.; Li, Y.; Sun, C.-J.; Chen, W.; Li, L.; Zhang, H.-B.; Yang, X.-D. Design, synthesis and biological evaluation of novel hybrid compounds of imidazole scaffold-based 2-benzylbenzofuran as potent anticancer agents. Eur. J. Med. Chem., 2013, 62, 111-121.

[162] Zeng, X.; Yang, X.; Zhang, Y. Qing, C.; Zhang, H. Synthesis and antitumor activity of 1-mesityl-3-(2-naphthoylmethano)-1H-imidazolium bromide. Bioorg. Med. Chem. Lett., 2010, 20, 1844-1847.

[163] Vlahakis, J.Z.; Lazar, C.; Crandall, I.E.; Szarek, W.A. Anti-plasmodium activity of imidazolium and triazolium salts. Bioorg. Med. Chem., 2010, 18, 6184-6196.

[164] Zhang, T.; Huang, L.-Z; Jia Wu, D.L.; Ma, B.-L; Du, Z.-T. Microwaveassisted synthesis of 2 -substituted $1 H$-benzo[ $d$ ] imidazoles and their antifungal activities in vitro. Heterocycles., 2013, 87, 1545-1552.

[165] Assadieskandar, A.; Amini, M.; Ostad, S.N.; Riazi, G. H.; Cheraghi-Shavi, T.; Shafiei, B.; Shafiee, A. Design, synthesis, cytotoxic evaluation and tubulin inhibitory activity of 4-aryl-5-(3,4,5-trimethoxyphenyl)-2-alkylthio-1 $\mathrm{H}$ imidazole derivatives. Bioorg. Med. Chem., 2013, 21, 2703-2709.

[166] Xiao, M.; Ahn, S.; Wang, J.; Chen, J.; Miller, D.D.; Dalton, J.T.; Li, W. Discovery of 4-aryl-2-benzoyl-imidazoles as tubulin polymerization inhibitor with potent antiproliferative properties. J. Med. Chem., 2013, 56, 3318-3329.
[167] Varga, L.; Nagy, T.; Kovesdi, I.; Benet-Buchholz, J.; Dorman, G.; Urge, L.; Darvas, F. Solution-phase parallel synthesis of 4,6-diaryl-pyrimidine-2ylamines and 2-amino-5,5-disubstituted-3,5-dihydroimidazol-4-ones via a rearrangement. Tetrahedron., 2003, 59, 655-662.

[168] Rajaguru, K.; Suresh, R.; Mariappan, A.; Muthusubramanian, S.; Bhuvanesh, N. Erbium triflate promoted multicomponent synthesis of highly substituted imidazoles. Org. Lett., 2014, 16, 744-747.

[169] Manetti, F.; Brullo, C.; Magnani, M.; Mosci, F.; Chelli, B.; Crespan, E.; Schenone, S.; Naldini, A.; Bruno, O.; Trincavelli, M.L.; Maga, G.; Carraro, F.; Martini, C.; Bondavalli, F.; Botta, M. Structure-based optimization of pyrazolo[3,4-d]pyrimidines as $\mathrm{Abl}$ inhibitors and antiproliferative agents toward human leukemia cell lines. J. Med. Chem., 2008, 51, 1252-1259.

[170] Chou, L.-C.; Huang, L.-J.; Yang, J.-S.; Lee, F.-Y.; Teng, C.-M.; Kuo, S.-C.; Synthesis of furopyrazole analogs of 1-benzyl-3-(5-hydroxymethyl-2furyl)indazole (YC-1) as novel anti-leukemia agents. Bioorg. Med. Chem., 2007, 15, 1732-1740.

[171] Xia, Y.; Dong, Z.-W.; Zhao, B.-X.; Ge, X.; Meng, N.; Shin, D.-S.; Miao, J.Y. Synthesis and structure-activity relationships of novel 1-arylmethyl-3aryl-1 $H$-pyrazole-5-carbohydrazide derivatives as potential agents against A549 lung cancer cells. Bioorg. Med. Chem., 2007, 15, 6893-6899.

[172] Schenone, S.; Bruno, O.; Ranise, A.; Bondavalli, F.; Brullo, C.; Fossa, P. Mosti, L.; Menozzi, G.; Carraro, F.; Naldini, A.; Bernini, C.; Manetti, F. Botta, M. New pyrazolo[3,4-d]pyrimidines endowed with A431 antiproliferative activity and inhibitory properties of Src phosphorylation. Bioorg. Med. Chem. Lett., 2004, 14, 2511-2517.

[173] Daidone, G.; Raffa, D.; Maggio, B.; Valeria Raimondi, M.; Plescia, F.; Schillaci, D. Synthesis and antiproliferative activity of triazenoindazoles and triazenopyrazoles: a comparative study. Eur. J. Med. Chem., 2004, 39, 219-224.

[174] Zhu, G.-D.; Gong, J.; Gandhi, V. B.; Woods, K.; Luo, Y.; Liu, X.; Guan, R.; Klinghofer, V.; Johnson, E.F.; Stoll, V. S.; Mamo, M.; Li, Q.; Rosenberg, S.H.; Giranda, V.L. Design and synthesis of pyridine-pyrazolopyridine-based inhibitors of protein kinase B/Akt. Bioorg. Med. Chem., 2007, 15, 24412452 .

[175] Warshakoon, N.C.; Wu, S.; Boyer, A.; Kawamoto, R.; Renock, S.; Xu, K Pokross, M.; Evdokimov, A.G.; Zhou, S.; Winter, C.; Walter, R.; Mekel, M. Design and synthesis of a series of novel pyrazolopyridines as HIF 1- $\alpha$ prolyl hydroxylase inhibitors. Bioorg. Med. Chem. Lett., 2006, 16, 5687-5690.

[176] Bhat, B.A.; Dhar, K.L.; Puri, S.C.; Saxena, A.K.; Shanmugavel, M.; Qazi, G.N. Synthesis and biological evaluation of chalcones and their derived pyrazoles as potential cytotoxic agents. Bioorg. Med. Chem. Lett., 2005, 15, 3177-3180.

[177] Desai, V.G.; Satardekar, P.C.; Polo, S.; Dhumaskar, K. Regioselective synthesis of 1,3,5-trisubstituted pyrazoles. Synth. Commun., 2012, 42, 836-842.

[178] Li, Y.-F.; Liu, Z.-Q. Dendritic antioxidants with pyrazole as the core: ability to scavenge radicals and to protect DNA. Free Rad. Biol. Med., 2012, 52, 103-108.

[179] Aggarwal, R.; Kumar, V.; Singh, S.P. Synthesis of some new 1-(6fluorobenzothiazol-2-yl)-3-(4-fluorophenyl)-5-arylpyrazolines and their iodine(III) mediated oxidation to corresponding pyrazoles. Indian J. Chem. B. 2007, 46, 1332-1336.

[180] Ponnala, S.; Sahu, D.P. Iodine-mediated synthesis of 2-arylbenzoxazoles, 2-arylbenzimidazoles, and 1,3,5-trisubstituted pyrazoles. Synth. Commun., 2006, 36, 2189-2194.

[181] Wang, B.X.; Liu, W.W.; Hu, H.W. A novel method for the synthesis of 1,3,5-triarylpyrazoles. Chem. J. Chin. Univ., 2003, 24, 648-650.

[182] Lokhande, P.D.; Waghamare, B.Y.; Sakate, S.S. Regioselective one-pot synthesis of 3,5-diarylpyrazoles. Indian J. Chem. B., 2005, 44, 2338-2342.

[183] Hemamalini, A.; Nagarajan, S.; Das, T.M. A facile synthesis of sugarpyrazole derivatives. Carbohydr. Res., 2011, 346, 1814-1819.

[184] Faidallah, H.M.; Makki, M.S.I.; Albar, H.A.; Sharshira, E.M. Synthesis of new pyrazoles from chalcones. Indian J. Heterocycl. Chem., 2001, 11, 21-26.

[185] Zhang, Z.; Tan, Y.-J.; Wang, C.-S.; Wu, H.-H. One-pot synthesis of 3,5diphenyl- $1 H$-pyrazoles from chalcones and hydrazine under mechanochemical ball milling. Heterocycles., 2014, 89, 103-112.

[186] Hamada, N.M. Synthesis and spectral studies of some novel pyrazole derivatives from chalcones precursors. Heterocycl. Commun., 2009, 15, 327-334.

[187] Agrawal, N.N.; Soni, P.A. Synthesis of pyrazole and isoxazole in triethanolamine medium. Indian J. Chem. B., 2007, 46, 532-534.

[188] Vijayvergiya, D.; Kothari, S.; Verma, B.L. Synthesis and biologial activity of some new 3,5-diaryl-1-phenyl/isonicotinoyl-2-pyrazolines and 3,5-diaryl-6carbethoxy cyclohexenone derivatives. Indian J. Heterocycl. Chem., 2003, $13,105-110$.

[189] Pinto, D.C.G.A.; Silva, A.M.S.; Cavaleiro, J.A.S.; Elguero, J. New bis(chalcones) and their transformation into bis(pyrazoline) and bis(pyrazole) derivatives. Eur. J. Org. Chem., 2003, 2003, 747-755.

[190] Prakash, O.; Sharma, D.; Kamal, R.; Kumar, R.; Nair, R.R. The chemistry of alpha,beta-ditosyloxyketones: new and convenient route for the synthesis of 1,4,5-trisubstituted pyrazoles from alpha,beta-chalcone ditosylates. Tetrahedron., 2009, 65, 10175-10181.

[191] Aggarwal, R.; Kumar, R. Iodobenzene diacetate mediated oxidation of $\mathrm{N}$ substituted hydrazones of chalcones: an efficient regioselective synthesis of 1,3,5-trisubstituted pyrazoles. Synth. Commun., 2009, 39, 2169-2177.

[192] LeBlanc, R.; Dickson, J.; Brown, T.; Stewart, M.; Pati, H.N.; VanDerveer, D.; Arman, H.; Harris, J.; Pennington, W.; Holt Jr, H.L.; Lee, M. Synthesis 
and cytotoxicity of epoxide and pyrazole analogs of the combretastatins. Bioorg. Med. Chem., 2005, 13, 6025-6034.

[193] Bhat, B.A.; Puri, S.C.; Qurishi, M.A.; Dhar, K.L.; Qazi, G.N. Synthesis of 3,5-diphenyl-1H-pyrazoles. Synth. Commun., 2005, 35, 1135-1142.

[194] Rao, V.K.; Tiwari, R.; Chhikara, B.S.; Shirazi, A.N.; Parang, K.; Kumar, A. Copper triflate-mediated synthesis of 1,3,5-triarylpyrazoles in [bmim] $\mathrm{PF}_{6}$ ionic liquid and evaluation of their anticancer activities. RSC Adv., 2013, 3 , 15396-15403.

[195] Outirite, M.; Lebrini, M.; Lagrenee, M.; Bentiss, F. New one step synthesis of 3,5-disubstituted pyrazoles under microwave irradiation and classical heating. J. Heterocycl. Chem., 2008, 45, 503-505.

[196] Corradi, A.; Leonelli, C.; Rizzuti, A.; Rosa, R.; Veronesi, P.; Grandi, R.; Baldassari, S.; Villa, C. New "green" approaches to the synthesis of pyrazole derivatives. Molecules., 2007, 12, 1482-1495.

[197] Landge, S.M.; Schmidt, A.; Outerbridge, V.; Török, B. Synthesis of pyrazoles by a one-pot tandem cyclization-dehydrogenation approach on $\mathrm{Pd} / \mathrm{C} / \mathrm{K}$ 10 catalyst. Synlett., 2007, 2007, 1600-1604.

[198] Khalil, O.M. Synthesis of some chalcones and pyrazolines carrying morpholinophenyl moiety as potential anti-inflammatory agents. Arch. Pharm., 2011, 344, 242-247.

[199] Bano, S.; Javed, K.; Ahmad, S.; Rathish, I.G.; Singh, S.; Alam, M.S. Synthesis and biological evaluation of some new 2-pyrazolines bearing benzene sulfonamide moiety as potential anti-inflammatory and anti-cancer agents. Eur. J. Med. Chem., 2011, 46, 5763-5768.

[200] Bashir, R.; Ovais, S.; Yaseen, S.; Hamid, H.; Alam, M. S.; Samim, M.; Singh, S.; Javed, K. Synthesis of some new 1,3,5-trisubstituted pyrazolines bearing benzene sulfonamide as anticancer and anti-inflammatory agents. Bioorg. Med. Chem. Lett., 2011, 21, 4301-4305.

[201] Thore, S.N.; Gupta, A.K. Synthesis of heterocyclic new pyrazolyl compounds. Indian J. Heterocycl. Chem., 2010, 19, 373-376.

[202] Shoman, M.E.; Abdel-Aziz, M.; Aly, O.M.; Farag, H.H.; Morsy, M.A. Synthesis and investigation of anti-inflammatory activity and gastric ulcerogenicity of novel nitric oxide-donating pyrazoline derivatives. Eur. J. Med. Chem., 2009, 44, 3068-3076.

[203] Johnson, M.; Younglove, B.; Lee, L.; LeBlanc, R.; Holt Jr, H.; Hills, P.; Mackay, H.; Brown, T.; Mooberry, S. L.; Lee, M.: Design, synthesis, and biological testing of pyrazoline derivatives of combretastatin-A4. Bioorg. Med. Chem. Lett., 2007, 17, 5897-5901.

[204] Ali, M.A.; Shaharyar, M.; Siddiqui, A.A. Synthesis, structural activity relationship and anti-tubercular activity of novel pyrazoline derivatives. Eur. J. Med. Chem., 2007, 42, 268-275.

[205] Parmar, P.J.; Rajput, S.I.; Doshi, A.G. Synthesis of some pyrazolines and its derivatives. Asian J. Chem., 2005, 17, 2539-2542.

[206] Vashi, K.; Naik, H.B. Synthesis of 1-substituted-3-(2'-hydroxy-3'-chloro-5'ethylphen-1'-yl)-5-aryl-2-pyrazoline. Asian J. Chem., 2005, 17, 409-414.

[207] Khadsan, R.E.; Kadu, M.V.; Doshi, A.G.; Aloolkar, N.H. Synthesis and antimicrobial activities of 3-(2-hydroxy-3-substituted-5-methylphenyl)-5(3,4-methylenidioxyphenyl)-2-pyrazoline and its derivatives. Asian J. Chem., 2005, 17, 1600-1604.

[208] Shinde, S.; Jadhav, W.; Pawar, R.; Bhusare, S. Synthesis and antibacterial activity of some 3,5-diphenyl and 1,3,5-triphenyl-2-pyrazolines. J. Chin. Chem. Soc., 2004, 51, 775-778.

[209] Deshmukh, A.Y.; Raghuwanshi, P.B.; Doshi, A.G. Synthesis of 3-(4''substituted phenyl)-5-(4'-substituted phenyl)- $\Delta(2)$-pyrazolines and their derivatives. Asian J. Chem., 2002, 14, 185-189.

[210] Venkataraman, S.; Jain, S.; Shah, K.; Upmanyu, N. Synthesis and biological activity of some novel pyrazolines. Acta Poloniae Pharm., 2010, 67, 361366.

[211] Aitmambetov, A.; Ibragimova, Z.Y.; Tokhtybaeva, A. Synthetic analogs of natural flavolignans. XII. Synthesis of 3,5-diarylsubstituted pyrazolines based on 1,3-benzodioxane and 1,4-benzodioxane chalcone analogs. Chem. Nat. Compd., 2004, 40, 541-543.

[212] Coskun, D.; Ahmedzade, M.; Kirbag, S. 3-(Substituted aryl)-1-benzofuranyl2-propenones: antimicrobial properties of some chalcones-type compounds and their 2-pyrazoline derivatives. E-J. Chem., 2011, 8, 1574-1581.

[213] Swamy, P.M.G.; Agasimundin, Y.S. Synthesis and antimicrobial activity of 3-(3'-hydroxybenzofuranyl)-5-aryl-pyrazolines. Indian J. Heterocycl. Chem., 2009, 18, 275-278.

[214] Rathish, I.G.; Javed, K.; Ahmad, S.; Bano, S.; Alam, M.S.; Pillai, K.K.; Singh, S.; Bagchi, V. Synthesis and antiinflammatory activity of some new 1,3,5-trisubstituted pyrazolines bearing benzene sulfonamide. Bioorg. Med. Chem. Lett., 2009, 19, 255-258.

[215] Azizian, J.; Shaabanzadeh, M.; Hatamjafari, F.; Mohammadizadeh, M.R. One-pot rapid and efficient synthesis of new spiro derivatives of $11 \mathrm{H}$ indeno[ $[1,2-b]$ quinoxalin-11-one, $6 H$-indeno[ $[1,2-b]$ pyrido[3,2-e]pyrazin-6one and isatin-based 2-pyrazolines. Arkivoc., 2006, xi, 47-58.

[216] Rizvi, S.U.F.; Siddiqui, H.L.; Ahmad, M.N.; Ahmad, M.; Bukhari, M.H.: Novel quinolyl-thienyl chalcones and their 2-pyrazoline derivatives with diverse substitution pattern as antileishmanial agents against Leishmania major. Med. Chem. Res., 2012, 21, 1322-1333.

[217] Bharmal, F.M.; Kaneriya, D.J.; Parekh, H.H. Synthesis of some pyrazoline derivatives as biologically active agents. Indian J. Heterocycl. Chem., 2001, 10, 189-192.

[218] Abdelhamid, A.O.; Abdelall, E.K.A.; Abdel-Riheem, N.A.; Ahmed, S.A. Synthesis and antimicrobial activity of some new 5-arylazothiazole, pyra- zolo[1,5-a]pyrimidine, $[1,2,4]$ triazolo[4,3-a]pyrimidine, and pyrimido $[1,2$ a]benzimidazole derivatives containing the thiazole moiety. Phosphorus Sulfur Silicon Relat. Elem., 2010, 185, 709-718.

[219] Jainey, P.; Bhat, I. Antitumor, analgesic, and anti-inflammatory activities of synthesized pyrazolines. J. Young Pharmacists., 2012, 4, 82-87.

[220] Bhagat, S.S.; Ghotekar, D.S.; Badadhe, P.V.; Chavan, N.M.; Dixit, P.P.; Gill, C.H. Synthesis and antimicrobial screening of pyrazolines and benzothiazepines incorporated with thiophene. Indian J. Heterocycl. Chem., 2011, 20, 355-358.

[221] Ramiz, M.M.M.; El-Sayed, W.A.; El-Tantawy, A.I.; Abdel-Rahman, A.A.H. Antimicrobial activity of new 4,6-disubstituted pyrimidine, pyrazoline, and pyran derivatives. Arch. Pharm. Res., 2010, 33, 647-654.

[222] Sridhar, S.; Rajendraprasad, Y. Synthesis and analgesic studies of some new 2-pyrazolines. E-J. Chem., 2012, 9, 1810-1815.

[223] Ramesh, B.; Sumana, T. Synthesis and anti-inflammatory activity of pyrazolines. E-J. Chem., 2010, 7, 514-516.

[224] Jamode, V.S.; Bhagat, P.R.; Chandak, H.S. Synthesis of some 3-4-(4chlorophenylsulphonamido)phenyl-5-aryl- $\Delta(2)$ pyrazolines. Asian J. Chem. 2003, 15, 897-900

[225] Anekal, D.; Biradar, J.S. Synthesis of novel substituted pyrazolines and isoxazolines containing indole and coumarins. Heterocycl. Commun., 2009, 15, 411-416.

[226] Parmar, P.J.; Rajput, S.I.; Doshi, A.G. Synthesis of some nitrosubstituted flavanones, pyrazolines and their derivatives. Asian J. Chem., 2007, 19, 493498.

[227] Chidananda, N.; Poojary, B.; Sumangala, V.; Kumari, N.S. Synthesis of some amino-pyrimidines and pyrazolines as potent antimicrobial agents. In dian J. Heterocycl. Chem., 2011, 20, 337-342.

[228] Parveen, H.; Iqbal, P.F.; Azam, A. Synthesis and characterization of a new series of hydroxy pyrazolines. Synth. Commun., 2008, 38, 3973-3983.

[229] Hawaiz, F.E.; Samad, M.K. Synthesis and spectroscopic characterization of some new biological active azo-pyrazoline derivatives. E-J. Chem., 2012, 9 , 1613-1622.

[230] Wani, M.Y.; Bhat, A.R.; Azam, A.; Lee, D.H.; Choi, I.; Athar, F. Synthesis and in vitro evaluation of novel tetrazole embedded 1,3,5-trisubstituted pyrazoline derivatives as Entamoeba histolytica growth inhibitors. Eur. J. Med. Chem., 2012, 54, 845-854.

[231] Gong, Z.-L.; Zheng, L.-W.; Zhao, B.-X. Synthesis, X-ray crystal structure and optical properties research of novel diphenyl sulfone-based bispyrazoline derivatives. J. Lumin., 2012, 132, 318-324.

[232] Ali, I.; Wani, W.A.; Khan, A.; Haque, A.; Ahmad, A.; Saleem, K.; Manzoor, $\mathrm{N}$. Synthesis and synergistic antifungal activities of a pyrazoline based ligand and its copper(II) and nickel(II) complexes with conventional antifungals. Microb. Pathog., 2012, 53, 66-73.

[233] Khalil, N.A.; Ahmed, E.M.; El-Nassan, H.B; Ahmed, O.K.; Al-Abd, A.M. Synthesis and biological evaluation of novel pyrazoline derivatives as antiinflammatory and antioxidant agents. Arch. Pharm. Res., 2012, 35, 9951002 .

[234] Hayat, F.; Salahuddin, A.; Umar, S.; Azam, A. Synthesis, characterization, antiamoebic activity and cytotoxicity of novel series of pyrazoline derivatives bearing quinoline tail. Eur. J. Med. Chem., 2010, 45, 4669-4675.

[235] Liu, W.-Y.; Xie, Y.-S.; Zhao, B.-X.; Wang, B.-S.; Lv, H.-S.; Gong, Z.-L; Lian, S.; Zheng, L.-W.: The synthesis, X-ray crystal structure and optical properties of novel 5-aryl-1-arylthiazolyl-3-ferrocenyl-pyrazoline derivatives. J. Photochem. Photobiol., A, 2010, 214, 135-144.

[236] Gong, Z.-L.; Zheng, L.-W.; Zhao, B.-X.; Yang, D.-Z.; Lv, H.-S.; Liu, W.-Y.; Lian, S. The synthesis, X-ray crystal structure and optical properties of novel 1,3,5-triaryl pyrazoline derivatives. J. Photochem. Photobiol., A, 2010, 209, $49-55$

[237] Abdel-Wahab, B.F.; Abdel-Aziz, H.A.; Ahmed, E.M. Synthesis and antimicrobial evaluation of 1-(benzofuran-2-yl)-4-nitro-3-arylbutan-1-ones and 3 (benzofuran-2-yl)-4,5-dihydro-5-aryl-1-4-(aryl)-1,3-thiazol-2-yl-1 $H$ pyrazoles. Eur. J. Med. Chem., 2009, 44, 2632-2635.

[238] Budakoti, A.; Bhat, A.R.; Athar, F.; Azam, A. Syntheses and evaluation of 3 (3-bromo phenyl)-5-phenyl-1-(thiazolo[4,5-b]quinoxaline-2-yl)-2-pyrazoline derivatives. Eur. J. Med. Chem., 2008, 43, 1749-1757.

[239] Budakoti, A.; Abid, M.; Azam, A.: Syntheses, characterization and in vitro antiamoebic activity of new Pd(II) complexes with 1-N-substituted thiocarbamoyl-3,5-diphenyl-2-pyrazoline derivatives. Eur. J. Med. Chem., 2007, 42, 544-551.

[240] Budakoti, A.; Abid, M.; Azam, A. Synthesis and antiamoebic activity of new 1-N-substituted thiocarbamoyl-3,5-diphenyl-2-pyrazoline derivatives and their Pd(II) complexes. Eur. J. Med. Chem., 2006, 41, 63-70.

[241] Kedar, R.M. Synthesis of 1-carboxamido-3,5-diaryl- $\Delta(2)$-pyrazolines and their antimicrobial study. Asian J. Chem., 2001, 13, 477-480.

[242] Sakthinathan, S.P.; Vanangamudi, G.; Thirunarayanan, G. Synthesis, spectra studies and antimicrobial activities of some 2-naphthyl pyrazoline derivatives. Spectrochim. Acta, Part A., 2012, 95, 693-700.

[243] Pant, G.J.N.; Singh, P.; Rawat, B.S.; Rawat, M.S.M.; Joshi, G.C. Synthesis, characterization and fluorescence studies of 3,5-diaryl substituted 2 pyrazolines. Spectrochim. Acta, Part A., 2011, 78, 1075-1079.

[244] Maleki, B.; Azarifar, D.; Moghaddam, M.K.; Hojati, S.F.; Gholizadeh, M.; Salehabadi, H. Synthesis and characterization of a series of 1,3,5trisubstituted-2-pyrazolines derivatives using methanoic acid under thermal condition. J. Serb. Chem. Soc., 2009, 74, 1371-1376. 
[245] Fioravanti, R.; Bolasco, A.; Manna, F.; Rossi, F.; Orallo, F.; Yanez, M.; Vitali, A.; Ortuso, F.; Alcaro, S. Synthesis and molecular modelling studies of prenylated pyrazolines as MAO-B inhibitors. Bioorg. Med. Chem. Lett., 2010, 20, 6479-6482.

[246] Sharma, P.K.; Kumar, S.; Kumar, P.; Kaushik, P.; Kaushik, D.; Dhingra, Y.; Aneja, K.R. Synthesis and biological evaluation of some pyrazolylpyrazolines as antiinflammatory-antimicrobial agents. Eur. J. Med. Chem., 2010, $45,2650-2655$.

[247] Shaharyar, M.; Siddiqui, A.A.; Ali, M.A.; Sriram, D.; Yogeeswari, P. Synthesis and in vitro antimycobacterial activity of $\mathrm{N}^{1}$-nicotinoyl-3-(4'-hydroxy3'-methyl phenyl)-5-[(sub)phenyl]-2-pyrazolines. Bioorg. Med. Chem. Lett., 2006, 16, 3947-3949.

[248] Manna, F.; Chimenti, F.; Fioravanti, R.; Bolasco, A.; Secci, D.; Chimenti, P.; Ferlini, C.; Scambia, G.: Synthesis of some pyrazole derivatives and preliminary investigation of their affinity binding to P-glycoprotein. Bioorg. Med. Chem. Lett., 2005, 15, 4632-4635.

[249] Lu, B.Q.; Zhang, J.M.; Wang, M.J.; Zhou, Y.H.; Chen, X.L. Synthesis and fluorescent property of pyrazoline derivatives. Chin. J. Chem., 2012, 30, 1345-1350.

[250] Amir, M.; Kumar, H.; Khan, S.A. Synthesis and pharmacological evaluation of pyrazoline derivatives as new anti-inflammatory and analgesic agents. Bioorg. Med. Chem. Lett., 2008, 18, 918-922.

[251] Insuasty, B.; Montoya, A.; Becerra, D.; Quiroga, J.; Abonia, R.; Robledo, S.; Vélez, I. D.; Upegui, Y.; Nogueras, M.; Cobo, J. Synthesis of novel analogs of 2-pyrazoline obtained from [(7-chloroquinolin-4-yl)amino]chalcones and hydrazine as potential antitumor and antimalarial agents. Eur. J. Med. Chem., 2013, 67, 252-262.

[252] Insuasty, B; Chamizo, L.; Munoz, J.; Tigreros, A.; Quiroga, J.; Abonia, R.; Nogueras, M.; Cobo, J. Synthesis of 1-substituted 3-aryl-5-aryl(hetaryl)-2pyrazolines and study of their antitumor activity. Arch. Pharm. Chem. Life Sci., 2012, 345, 275-286.

[253] Rana, A.K.; Lade, S.B.; Sorathia, S.; Joshi, M.J.; Shah, N.M. Synthesis, characterization and antimicrobial evaluation of some new $\mathrm{N}$-acetyl pyrazoline derivatives from substituted furan-2-carbaldehyde. Der Chem. Sin., 2012, 3, 965-969.

[254] Samshuddin, S.; Narayana, B.; Sarojini, B.K.; Khan, M.T.H.; Yathirajan, H.S.; Raj, C.G.D.; Raghavendra, R. Antimicrobial, analgesic, DPPH scavenging activities and molecular docking study of some 1,3,5-triaryl-2pyrazolines. Med. Chem. Res., 2012, 21, 2012-2022.

[255] Manna, K.; Agrawal, Y.K. Potent in vitro and in vivo antitubercular activity of certain newly synthesized indophenazine 1,3,5-trisubstituted pyrazoline derivatives bearing benzofuran. Med. Chem. Res., 2011, 20, 300-306.

[256] Sivakumar, P.M.; Seenivasan, S.P.; Kumar, V.; Doble, M. Novel 1,3,5triphenyl-2-pyrazolines as anti-infective agents. Bioorg. Med. Chem. Lett., 2010, 20, 3169-3172.

[257] Wanare, G.; Aher, R.; Kawathekar, N.; Ranjan, R.; Kaushik, N.K.; Sahal, D. Synthesis of novel alpha-pyranochalcones and pyrazoline derivatives as Plasmodium falciparum growth inhibitors. Bioorg. Med. Chem. Lett., 2010, 20, 4675-4678.

[258] Sivakumar, P.M.; Ganesan, S.; Veluchamy, P.; Doble, M. Novel chalcones and 1,3,5-triphenyl-2-pyrazoline derivatives as antibacterial agents. Chem. Biol. Drug Des., 2010, 76, 407-411.

[259] Revanasiddappa, B.C.; Rao, R.N.; Subrahmanyam, E.V.S.; Satyanarayana, D. Synthesis and biological evaluation of some novel 1, 3, 5-trisubstituted pyrazolines. E-J. Chem., 2010, 7, 295-298.

[260] Gautam, N.; Chourasia, O.P. Synthesis, antimicrobial and insecticidal activity of some new cinnoline based chalcones and cinnolinc based pyrazoline derivatives. Indian J. Chem. B., 2010, 49, 830-835.

[261] Nagashree, A.S.; Chandrashekhar, C.; Vaidya, V.P. Synthesis of 1- $N$-phenyl3-\{3-nitronaphtho[2,1-b]fur-2-yl\}-5-aryl-2-pyrazolines and their biological activities. Indian J. Heterocycl. Chem., 2010, 20, 65-68.

[262] Bhat, K.I.; Hussain, M.M.M. Synthesis, characterization and antimicrobial studies of some substituted pyrazolines from aryloxy acetyl hydrazine. Asian J. Chem., 2009, 21, 3371-3375.

[263] Bhat, K.I.; Kumar, D.U.P. Synthesis, characterization and biological evaluation of some 1,3,5-trisubstituted-2-pyrazolines. Asian J. Chem., 2009, 21, 3376-3380.

[264] Ali, M.A.; Yar, M.S.; Siddiqui, A.A.; Sriram, D.; Yogeeswari, P.; De Clercq, E. Synthesis and anti-HIV activity of $N^{\prime}$-nicotinoyl-3-(4'-hydroxy-3'methylphenyl)-5-substituted phenyl-2-pyrazolines. Acta Poloniae Pharm., 2007, 64, 423-428.

[265] Al Bahtiti, N.H. Synthesis, characterization, and antibacterial activity of some 5-aryl-1,3-diphenyl-4,5-dihydro-1H-pyrazoles. Arab Gulf J. Sci. Res., $\mathbf{2 0 0 7}, 25,1-5$

[266] Havaldar, F.H.; Khatri, N.K.: Synthesis and biological activity of 2-(3carboxy phenyl)-5-(4-substituted phenyl)-1-acetyl-2-pyrazolines. Asian J. Chem., 2007, 19, 5093-5097.

[267] Suthakaran, R.; Somasekhar, G.; Sridevi, C.; Marikannan, M.; Suganthi, K.; Nagarajan, G. Synthesis, antiinflammatory, antioxidant and antibacterial activities of 7-methoxy benzofuran pyrazoline derivatives. Asian J. Chem., 2007, 19, 3353-3362.

[268] Ali, M.A.; Yar, M.S.; Kumar, M.; Pandian, G.S. Synthesis and antitubercular activity of substituted novel pyrazoline derivatives. Nat. Prod. Res., 2007, $21,575-579$.
[269] Li, F.; Xie, Z.-F.; Liu, F.-M.: Syntheses and fluorescent property of 5-(2phenyl-1,2,3-triazoly)-3-aryl pyrazoline derivatives. Chem. J. Chin. Univer., 2006, 27, 1058-1061

[270] Saundane, A.R.; Badiger, J.; Sharma, P.M.V. Synthesis and antimicrobial activity of some indole derivatives containing pyrazoline and benzodiazepine systems. Indian J. Heterocycl. Chem., 2005, 14, 331-334.

[271] Nimavat, K.S.; Popat, K.H.; Joshi, H.S. Synthesis, anticancer, antitubercular and antimicrobial activity of 1-substituted 3-aryl-5-(3'-bromophenyl)pyrazolines. Indian J. Heterocycl. Chem., 2003, 12, 225-228.

[272] Azarifar, D.; Shaebanzadeh, M. Synthesis and characterization of new 3,5dinaphthyl substituted 2-pyrazolines and study of their antimicrobial activity. Molecules., 2002, 7, 885-895.

[273] Hassan, S.Y. Synthesis and biological activity of some new pyrazoline and pyrimidine derivatives. J. Braz. Chem. Soc., 2011, 22, 1286-1298.

[274] Lévai, A.; Jekő, J.; Brahmbhatt, D.I. Synthesis of 1-substituted 5-aryl-3-(3 coumarinyl)-2-pyrazolines by the reaction of 3-aryl-1-(3-coumarinyl)propen1-ones with hydrazines. J. Heterocycl. Chem., 2005, 42, 1231-1235.

[275] Dighade, S.R.; Chincholkar, M.M. Synthesis of some new chalcones, 3aroylflavanones, 3-aroylchromanones and their derivatives as 1-aryl-3-(2hydroxy-5-methylphenyl)-5,5-dialkyl/5,5-diaryl/5-aryl/4-aroy 1 -5-aryl- $\Delta(2)$ pyrazolines. Asian J. Chem., 2001, 13, 1606-1612.

[276] Patel, V.G.; Patel, B.K.; Patel, J.C.: Synthesis, characterization and antimicrobial activity of substituted phenyl-5-(8-hydroxy quinolinol-5-yl) pyrazolines. Asian J. Chem., 2004, 16, 1773-1778.

[277] Solankee, A.; Kapadia, K.; Lad, S.; Patel, J.; Thakor, I. Synthesis and antimicrobial activity of s-triazine based chalcones, pyrazolines and amino pyrimidines. Asian J. Chem., 2004, 16, 727-732.

[278] Solankee, A.; Patel, J. Synthesis of chalcones, pyrazolines, aminopyrimidines and pyrimidine thiones as anti-bacterial agents. Indian J. Chem. B., 2004, 43, 1580-1584.

[279] Gong, Z.-L.; Xie, Y.-S.; Zhao, B.-X.; Lv, H.-S.; Liu, W.-Y.; Zheng, L.-W Lian, S. The synthesis, X-ray crystal structure and optical properties of novel 5-aryl-3-ferrocenyl-1-pyridazinyl-pyrazoline derivatives. J. Fluoresc., 2011, 21,355-364.

[280] Smuilovich, K.S.; Orlova, N.A.; Karpova, E.V.; Shakirov, M.M.; Shelkovnikov, V.V.: Reactions of polyfluorinated chalcones with hydrazine hydrate and phenylhydrazine. Russ. Chem. Bull., 2010, 59, 1408-1413.

[281] Santos, C.M.M.; Silva, A.M.S.; Jekő, J.; Lévai, A. Synthesis and structure elucidation of novel pyrazolyl-2-pyrazolines obtained by the reaction of 3-(3aryl-3-oxopropenyl)chromen-4-ones with phenylhydrazine. Arkivoc., 2012 , $v, 265-281$.

[282] Lévai, A.; Jekő, J.: Synthesis of carboxylic acid derivatives of 2-pyrazolines. Arkivoc., 2007, $i, 134-145$

[283] Lévai, A.; Jekő, J. Synthesis of hydroxylated 3,5-diaryl-2-pyrazolines by the reaction of hydroxychalcones with hydrazines. Arkivoc., 2005, $x, 199-205$.

[284] Xie, Z.; Mo, X.; Liu, G.; Liu, F. Synthesis and crystal structure of 5-pyrazol4,5-dihydropyrazoles derivatives. J. Heterocycl. Chem., 2008, 45, 14851488

[285] Lévai, A.; Jekö, J. Synthesis of 1-substituted 3,5-diaryl-2-pyrazolines by the reaction of alpha,beta-unsaturated ketones with hydrazines. J. Heterocycl Chem., 2006, 43, 111-115.

[286] Singh, P.; Negi, J.S.; Pant, G.J.N.; Rawat, M.S.M. Synthesis and characterization of novel 1-chloroacetyl derivatives of 2-pyrazolines. Heterocycl. Commun., 2011, 17, 61-63.

[287] Khan, S.S.; Hasan, A. Synthesis of some new bioactive 1- $N$-subtituted 3,5diaryl-2-pyrazolines. Heterocycl. Commun., 2007, 13, 131-138.

[288] Khan, S.S.; Hasan, A. Synthesis of some new bioactive 1-N-acid hydrazide substituted pyrazolines. Heterocycl. Commun., 2006, 12, 377-382.

[289] Kolos, N.N.; Paponov, B.V.; Orlov, V.D.; Lvovskaya, M.I.; Doroshenko, A.O.; Shishkin, O.V. Derivatives of $\Delta 2$-pyrazoline-products of 1,5 diaminotetrazole interaction with chalcone: molecular structure and spectral properties. J. Mol. Struct., 2006, 785, 114-122.

[290] Kumara, T.H.S.; Mahadevan, K.M.; Harishkumar, H.N.; Padmashali, B Naganagowda, G. Synthesis of benzo[b] thiophene substituted carbamates, ureas, semicarbazides, and pyrazoles and their antimicrobial and analgesic activity. Phosphorus Sulfur Silicon Relat. Elem., 2009, 184, 1866-1879.

[291] Kumaraswamy, M.N.; Chandrashekhar, C.; Shivakumar, H.; Mathias, D.A.P.; Mahadevan, K.M.; Vaidya, V.P. Synthesis and activity evaluation of 2-(1-naphtho[2,1-b]furan-2-yl-carbonyl)-3,5-disubstituted-2,3-dihydro- $1 \mathrm{H}$ pyrazoles. Indian J: Pharm. Sci., 2008, 70, 715-720.

[292] Nair, V.; Mathew, S.C.; Biju, A.T.; Suresh, E. A novel reaction of the "Huisgen zwitterion" with chalcones and dienones: An efficient strategy for the synthesis of pyrazoline and pyrazolopyridazine derivatives. Angew. Chem. Int. Ed., 2007, 46, 2070-2073.

[293] Barsoum, F.F.; Hosni, H.M.; Girgis, A.S. Novel bis(1-acyl-2-pyrazolines) of potential anti-inflammatory and molluscicidal properties. Bioorg. Med. Chem., 2006, 14, 3929-3937.

[294] Bhatt, A.H.; Parekh, H.H.; Parikh, K.A.; Parikh, A.R. Synthesis of pyrazolines and cyanopyridines as potential antimicrobial agents. Indian J. Chem B., 2001, 40, 57-61

[295] Jat, J.; Ojha, S.; Bhambi, D.; Dhakar, N.; Talesara, G.L. Synthesis and characterization of biologically significant 5,5'-(1,4-phenylene)bis(1-Nalkoxyphthalimido-3-aryl-2-pyrazoline) derivatives. J. Enzyme Inhib. Med. Chem., 2008, 23, 882-887. 
[296] Bhat, A.R.; Athar, F.; Azam, A. Bis-pyrazolines: Synthesis, characterization and antiamoebic activity as inhibitors of growth of Entamoeba histolytica. Eur. J. Med. Chem., 2009, 44, 426-431.

[297] Kundariya, D.S.; Rupala, R.G.; Patel, P.K. Synthesis and antimicrobial screening of some novel pyrazoline derivatives. Asian J. Chem., 2012, 24 , 2045-2048.

[298] Cacic, M.; Molnar, M.; Strelec, I. Synthesis and biological evaluation of a novel series of 1,3-dicoumarinyl-5-aryl-2-pyrazolines. Heterocycles., 2011, 83, 1553-1566.

[299] Ghotekar, D.S.; Mandhane, P.G.; Joshi, R.S.; Bhagat, S.S.; Gill, C.H. Synthesis of chromones and pyrazolines as antimicrobial \& antifungal agents. Indian J. Heterocycl. Chem., 2010, 19, 341-344.

[300] Ghotekar, D.S.; Mandhane, P.G.; Joshi, R.S.; Bhagat, S.S.; Gill, C.H. Synthesis of biologically important chromones and pyrazolines. Indian J. Heterocycl. Chem., 2009, 19, 101-104.

[301] Drabu, S.; Rana, A.; Kumar, H. Synthesis, antiinflammatory, ulcerogenic and antibacterial activities of 1,3,5-trisubstituted pyrazolines. Indian J. Heterocycl. Chem., 2007, 16, 399-400.

[302] Agarwal, Y.K.; Manna, K.; Bhatt, H.; Gogai, P.; Babu, V.H.; Srinivasan, K.K. Synthesis and biological evaluations of new benzofuran 1,3,5trisubstituted pyrazoline derivatives of paracetamol as potential antitubercular, antimicrobial agents. Indian J. Heterocycl. Chem., 2007, 16, 263-266.

[303] Upadhyay, T.M.; Barot, V.M. Synthesis and biological evaluation of some new pyrazolines. Indian J. Heterocycl. Chem., 2006, 15, 393-394.

[304] Kolhe, S.V.; Doshi, A.G.; Raut, A.W. Synthesis of new pyrazolines and their derivatives. Indian J. Heterocycl. Chem., 2003, 12, 281-282.

[305] Archana; Srivastava, V.K.; Kumar, A. Synthesis and anticonvulsant activity of 1-acetyl-5-arylidenyl-3-(2'-oxo/thiobarbiturinyl)-2-pyrazolines. Arzneimittel-Forschung-Drug Res., 2002, 52, 787-791.

[306] Desai, J.; Nair, K.B.; Misra, A.N. Synthesis and antimicrobial activities of some new pyrazolines phenyl pyrazolines, flavanones and related compounds. Indian J. Heterocycl. Chem., 2001, 10, 261-266.

[307] Xie, Z.; Bian, X.; Geng, X.; Li, S.; Wang, C. Novel synthesis of 1,3,5trisubstituted 2-pyrazolines promoted by chlorotrimethylsilane. J. Chem. Res., 2008, 52-54.

[308] Mahe, O.; Frath, D.; Dez, I.; Marsais, F.; Levacher, V.; Briere, J.-F. TBDorganocatalysed synthesis of pyrazolines. Org. Biomol. Chem., 2009, 7, 3648-3651.

[309] Fazaeli, R.; Aliyan, H.; Mallakpour, S.; Rafiee, Z.; Bordbar, M. Tungstophosphoric acid supported on highly organosoluble polyamide (PW12/PA): highly efficient catalysts for the synthesis of novel 1,3,5-triaryl-2-pyrazoline derivatives. Chin. J. Catal., 2011, 32, 582-588.

[310] Fazaeli, R.; Aliyan, H.; Tangestaninejad, S.; Mohammadi, E.; Bordbar, M. Nanocasting, template synthesis, and structural studies on cesium salt of phosphotungstic acid for the synthesis of novel 1,3,5-triaryl-pyrazoline derivatives. Chin. J. Catal., 2012, 33, 237-246.

[311] Mahe, O.; Dez, I.; Levacher, V.; Briere, J.-F. Enantioselective synthesis of bio-relevant 3,5-diaryl pyrazolines. Org. Biomol. Chem., 2012, 10, 39463954.

[312] Karthikeyan, P.; Kumar, S.S.; Jagadeesh, R.V.; Bhagat, P.R. Solvent-free synthesis of substituted-2-pyrazolines using imidazolium based ionic liquid as a solvent and catalyst: a green route approach. Asian J. Chem., 2012, 24, $1351-1353$

[313] Wu, X.-F.; Jiao, H.; Neumann, H.; Beller, M. Progress in carbonylative-Heck reactions of aryl bromides: catalysis and DFT studies. ChemCatChem., 2011, 3, 726-733.

[314] Wu, X.-F.; Neumann, H.; Beller, M. A straightforward synthesis of pyrazolines and pyrazoles: palladium-catalyzed carbonylative vinylationcyclocondensation reactions of aryl halides. Eur. J. Org. Chem., 2011, 49194924.

[315] Zangade, S.; Shinde, A.; Patil, A.; Vibhute, Y. An efficient and facile ring closure of 2'-hydroxychalcones under irradiation of tungsten light. Eur. J. Chem., 2012, 3, 208-210.

[316] Dawane, B.S.; Konda, S.G.; Mandawad, G.G.; Shaikh, B.M. Poly(ethylene glycol) (PEG-400) as an alternative reaction solvent for the synthesis of some new 1-(4-(4'-chlorophenyl)-2-thiazolyl)-3-aryl-5-(2-butyl-4-chloro$1 H$-imidazol-5yl)-2-pyrazolines and their in vitro antimicrobial evaluation. Eur. J. Med. Chem., 2010, 45, 387-392.

[317] Konda, S.G.; Dawane, B.S. Synthesis and antimicrobial properties of some new imidazolyl 2-pyrazolines. Indian J. Heterocycl. Chem., 2010, 20, 153156.

[318] Deshmukh, D.R.; Berad, B.N.; Raut, A.R.; Banewar, V.W. Microwave induced synthesis of some novel heterocycles from substituted chalcones. Asian J. Chem., 2011, 23, 499-501.

[319] Chawla, R.; Sahoo, U.; Arora, A.; Sharma, P.C.; Radhakrishnan, V. Microwave assisted synthesis of some novel 2-pyrazoline derivatives as possible antimicrobial agents. Acta Poloniae Pharm., 2010, 67, 55-61.

[320] Rao, J.N.; Sujith, K.V.; Kalluraya, B. An efficient microwave assisted synthesis of some pyrazolines and their biological activity. Indian J. Heterocycl. Chem., 2009, 18, 365-368.

[321] Dubey, R.R.; Dhawas, A.K.; Thakare, S.S.: Novel synthesis of some acetoxy aryl pyrazolines. Asian J. Chem., 2009, 21, 6233-6236.

[322] Pujar, G.V.; Synesh, C.; Purohit, M.N.; Srinivasalu, N.; Udupi, R.H. Synthesis, anticonvulsant and antibacterial activities of some novel pyrazolines de- rived from benzoxazole and benzimidazole. Indian J. Heterocycl. Chem. 2008, 17, 387-388.

[323] Katade, S.; Phalgune, U.; Biswas, S.; Wakharkar, R.; Deshpande, N. Microwave studies on synthesis of biologically active chalcone derivatives. Indian J. Chem. B., 2008, 47, 927-931.

[324] Rao, S.S.; Gahlot, U.S.; Dulawat, S.S.; Vyas, R.; Ameta, K.L.; Verma, B.L. Microwave-induced improved synthesis and antibacterial activities of some chalcones and their 1-acyl-3,5-diaryl-2-pyrazolines. Afinidad., 2003, 60, 271276.

[325] Azarifar, D.; Ghasemnejad, H.: Microwave-assisted synthesis of some 3,5arylated 2-pyrazolines. Molecules, 2003, 8, 642-648.

[326] Rao, J.N.; Sujith, K.V.; Kalluraya, B. An efficient microwave assisted synthesis of some pyrazolines and their biological activity. Indian J. Heterocycl. Chem., 2009, 18, 365-368.

[327] Biradar, J.S.; Mugali, P.S.; Sharanbasappa, B.; Sasidhar, B.S. Improved synthesis of some pyrazolines under microwave. Indian J. Heterocycl. Chem., 2008, 18, 141-144

[328] Siddiqui, Z.N.; Farooq, F.; Musthafa, T.N.M. A highly efficient, simple, and ecofriendly microwave-induced synthesis of indolyl chalcones and pyrazolines. Green Chem. Lett. Rev., 2011, 4, 63-68.

[329] Zahran, M.A.H.; Salama, H.F.; Abdin, Y.G.; Gamal-Eldeen, A.M. Efficient microwave irradiation enhanced stereoselective synthesis and antitumor activity of indolylchalcones and their pyrazoline analogs. J. Chem. Sci., 2010 $122,587-595$.

[330] Insuasty, B.; Tigreros, A.; Orozco, F.; Quiroga, J.; Abonia, R.; Nogueras, M Sanchez, A.; Cobo, J. Synthesis of novel pyrazolic analogues of chalcones and their 3-aryl-4-(3-aryl-4,5-dihydro-1H-pyrazol-5-yl)-1-phenyl-1 $H$ pyrazole derivatives as potential antitumor agents. Bioorg. Med. Chem. 2010, $18,4965-4974$

[331] Munawar, M.A.; Azad, M.; Athar, M.; Groundwater, P.W. Synthesis and antimicrobial activity of quinoline-based 2-pyrazolines. Chem. Papers., 2008, 62, 288-293.

[332] Rajora, J.; Yadav, J.; Kumar, R.; Srivastava, Y.K. Microwave assisted transformation of benzimidazolyl chalcones into N-1-substituted pyrazolines and evaluation of their antimicrobial activities. Indian J. Chem. B., 2010, 49 , 989-993.

[333] Siddiqui, Z.N.; Musthafa, T.N.M.; Ahmad. A.; Khan, A. U. Thermal solventfree synthesis of novel pyrazolyl chalc nes py as potential antimicrobial agents. Bioorg. Med. Chem. 2011, $260-2865$.

[334] Sharma, S.; Sharma, A. Solvent-free synthesis of new-1-acetyl-3-(4fluoronaphthyl)-5-substituted aryl pyrazolines as spermicides. J. Indian Chem. Soc., 2008, 85, 750-753.

[335] Pathak, V.N.; Gupta, R.; Gupta, N. Synthesis and biological evaluation of some new 4,5-dihydro-3-(2-aryl-indol-3-yl)-5-(4-chlorophenyl)-N(1) phenylpyrazoles. Indian J. Chem. B., 2008, 47, 1303-1307.

[336] Kidwai, M.; Misra, P. Ring closure reactions of chalcones using microwave technology. Synth. Commun., 1999, 29, 3237-3250.

[337] Puri, S.; Kaur, B.; Parmar, A. Kumar, H. Applications of ultrasound in organic synthesis - a green approach. Curr. Org. Chem., 2013, 17, 1790-1828.

[338] Gupta, R.; Gupta, N.; Jain, A. Improved synthesis of chalcones and pyrazolines under ultrasonic irradiation. Indian J. Chem. B., 2010, 49, 351-355.

[339] Pizzuti, L.; Piovesan, L.A.; Flores, A.F.C.; Quina, F.H.; Pereira, C.M.P. Environmentally friendly sonocatalysis promoted preparation of 1 thiocarbamoyl-3,5-diaryl-4,5-dihydro-1H-pyrazoles. Ultrason. Sonochem., 2009, 16, 728-731.

[340] Li, J.-T.; Zhang, X.-H.; Lin, Z.-P. An improved synthesis of 1,3,5-triaryl-2pyrazolines in acetic acid aqueous solution under ultrasound irradiation. Beilstein J. Org. Chem., 2007, 3, 1-4.

[341] Shelke, S.N.; Mhaske, G.R.; Bonifacio, V.D.B.; Gawande, M.B. Green synthesis and anti-infective activities of fluorinated pyrazoline derivatives. Bioorg. Med. Chem. Lett., 2012, 22, 5727-5730.

[342] Lévai, A.; Jekő, J. Synthesis of 3-aroyl-4-(3-chromonyl)-2-pyrazolines. $J$. Heterocycl. Chem., 2002, 39, 1333-1336.

[343] Xie, H.; Zhu, J.; Chen, Z.; Li, S.; Wu, Y. Reaction of a trifluoromethylated $N$-monosubstituted hydrazone with alpha,beta-ethenyl ketones: a novel synthesis of substituted pyrazolidines and pyrazolines. Synthesis., 2011, 27672774

[344] Ali, N.A.S.; Dar, B.A.; Pradhan, V.; Farooqui, M. Chemistry and biology of indoles and indazoles: a mini-review. Mini-Rev. Med. Chem., 2013, 13, $1792-800$

[345] Cerecetto, H.; Gerpe, A.; Gonzalez, M.; Aran, V.J.; de Ocariz, C.O. Pharmacological properties of indazole derivatives: recent developments. Mini-Rev. Med. Chem., 2005, 5, 869-878.

[346] Pawar, M.P.; Vyas, K.; Shah, N.M.; Nivamat, K. Synthesis and antimicrobial activity of some new indazolone derivatives from 1-(3,5-Dibromo-2 hydroxy-4-methylphenyl) ethanone. Int. J. Pharm. Res. Scholars., 2012, 1, 211-216.

[347] Vyas, D.H.; Tala, S.D.; Akbari, J.D.; Dhaduk, M.F.; Joshi, H.S. Synthesis, antimicrobial and antitubercular activity of some cyclohexenone and indazole derivatives. Indian J. Chem. B., 2009, 48, 1405-1410.

[348] Sachar, A.; Kumar, S.; Sharma, R.L. A facile synthesis of pyridoquinazoline, pyridopyrimidine, benzoxazole and indazole derivatives from chalcones. In dian J. Heterocycl. Chem., 2006, 16, 39-42.

[349] Popat, K.H.; Nimavat, K.S.; Vasoya, S.L.; Joshi, H.S. Synthesis, anticancer, antitubercular and antimicrobial activity of 6-carbethoxy-5-(3' 
chlorophenyl)-3-aryl-2-cyclohexenones and 6-aryl-4-(3'-chlorophenyl)-3oxo-2,3a,4,5-tetrahydro- $1 H$-indazoles. Indian J. Chem. B., 2003, 42, 1497 1501 .

[350] Nimavat, K.S.; Popat, K.H.; Joshi, H.S. Synthesis and pharmacological evaluation of 6-carbethoxy-5-(3'-bromophenyl)-3-aryl-2-cyclohexenones and 6-aryl-4-(3'-bromophenyl)-3-oxo-2,3a,4,5-tetrahydro- $2 H$-indazoles. $J$. Sci. Isl. Rep. Iran., 2002, 13, 323-326.

[351] Rao, N.S.; Bajia, B.; Srivastava, Y.K.; Kumar, R. Microwave induced synthesis and antibacterial activity of some 6-(2-hyroxyphenyl)-4-(substituted phenyl)-3-oxo-2,3,4,5-tetrahydro-1H-indazoles. E-J. Chem., 2008, 5, 39-42.

[352] Yadav, J.S.; Rajora, J.; Srivastava, Y.K.: Some transformations of benzimidazolyl chalcones using MAOS protocol- a green approach. Arch. Appl. Sci. Res., 2011, 3, 192-198.

[353] Shakil, N.A.; Singh, M.K.; Sathiyendiran, M.; Kumar, J.; Padaria, J C. Microwave synthesis, characterization and bio-efficacy evaluation of novel chalcone based 6-carbethoxy-2-cyclohexen-1-one and $2 \mathrm{H}$-indazol-3-ol derivatives. Eur. J. Med. Chem., 2013, 59, 120-131.

[354] Bhatia, R.K.; Raju, P.B.; Jain, U.K.; Kumar, P.P.; Satyavathi, K. Synthesis and anti-inflammatory activities of 7-benzylidene-2,3-diphenyl-4,5,6,7tetrahydro- $2 H$-indazole derivatives. Res. J. Pharm. Biol. Chem. Sci., 2011, 2 , $118-129$.

[355] Chang, M.-Y.; Tai, H.-Y.; Chen, Y.-L.; Hsu, R.-T. Synthesis of 1,3-diaryl$1 H$-benzo[ $g$ ] indazoles. Tetrahedron., 2012, 68, 7941-7948.

[356] Herbrecht, R. Posaconazole: a potent, extended-spectrum triazole anti-fungal for the treatment of serious fungal infections. Int. J. Clin. Pract., 2004, 58, 612-624.

[357] Arikan, S.; Rex, J.H. Ravuconazole Eisai/Bristol-Myers Squibb. Curr. Opin. Investig. Drugs., 2002, 3, 555-561.

[358] Chandrasekar, P.H.; Manavathu, E. Voriconazole: a second-generation triazole. Drugs Today., 2001, 37, 135-148.

[359] da Silva, F.D.C.; de Souza, M.C.B.V.; Frugulhetti, I.I.P.; Castro, H.C.; Souza, S.L.D.O.; de Souza, T.M.L.; Rodrigues, D.Q.; Souza, A.M.T.; Abreu, P.A.; Passamani, F.; Rodrigues, C.R.; Ferreira, V.F. Synthesis, HIV-RT inhibitory activity and SAR of 1-benzyl-1H-1,2,3-triazole derivatives of carbohydrates. Eur. J. Med. Chem., 2009, 44, 373-383.

[360] Alexacou, K.-M.; Hayes, J.M.; Tiraidis, C.; Zographos, S.E.; Leonidas, D.D.; Chrysina, E.D.; Archontis, G.; Oikonomakos, N.G.; Paul, J.V.; Varghese, B.; Loganathan, D. Crystallographic and computational studies on 4-phenyl- $N$ ( $\beta$-D-glucopyranosyl)-1 $\mathrm{H}$-1,2,3-triazole-1-acetamide, an inhibitor of glycogen phosphorylase: Comparison with $\alpha$-D-glucose, $N$-acetyl- $\beta$-Dglucopyranosylamine and $N$-benzoyl- $N$ '- $\beta$-D-glucopyranosyl urea binding. Proteins Struct. Funct. Bioinf., 2008, 71, 1307-1323.

[361] Genin, M.J.; Allwine, D.A.; Anderson, D.J.; Barbachyn, M.R.; Emmert, D.E.; Garmon, S.A.; Graber, D.R.; Grega, K.C.; Hester, J.B.; Hutchinson, D.K.; Morris, J.; Reischer, R.J.; Ford, C.W.; Zurenko, G.E.; Hamel, J.C.; Schaadt, R.D.; Stapert, D.; Yagi, B.H. Substituent effects on the antibacterial activity of nitrogen-carbon-linked (azolylphenyl) oxazolidinones with expanded activity against the fastidious Gram-negative organisms Haemophilus influenzae and Moraxella catarrhalis. J. Med. Chem., 2000, 43, 953-970.

[362] Morgan, N. H. (Chomerics, Inc.), Eur. Pat. Appl., EP 437979 A2 19910724, 1991.

[363] Fan, W.Q.; Katritzky A.R. In: Comprehensive Heterocyclic Chemistry II; Katritzky, A.R.; Rees, C.W.; Scriven, E.F.V. Eds.; Pergamon Press, Oxford, 1996; Vol. 4, pp. 1-126.

[364] Willis, R.J.M., I. D. Eur. Pat. Appl. 400842, 1990; Chem. Abstr., 1991, 114, $164247 \mathrm{~b}$.

[365] Zhang, Y.; Li, X.; Li, J.; Chen, J.; Meng, X.; Zhao, M.; Chen, B. CuOpromoted construction of $\mathrm{N}$-2-aryl-substituted-1,2,3-triazoles via azidechalcone oxidative cycloaddition and post-triazole arylation. Org. Lett., 2012, 14, 26-29.

[366] Kamal, A.; Swapna, P. An improved iron-mediated synthesis of $\mathrm{N}$-2-aryl substituted 1,2,3-triazoles. RSC Adv, 2013,3,7419-7426.

[367] Singh, N.; Pandey, S.K.; Tripathi, R.P. Regioselective [3+2] cycloaddition of chalcones with a sugar azide: easy access to 1-(5-deoxy-D-xylofuranos-5-yl)4,5-disubstituted-1H-1,2,3-triazoles. Carbohydr. Res., 2010, 345, 1641-1648.

[368] Katritzky, A.R.; Pastor, A.; Voronkov, M.; Steel, P.J. Novel one-step synthesis of thiazolo[3,2-b]1,2,4-triazoles. Org. Lett., 2000, 2, 429-431.

[369] Ostrovskii, V.A.; Trifonov, R.E.; Popova, E.A. Medicinal chemistry of tetrazoles. Russ. Chem. Bull., 2012, 61, 768-780.

[370] Borgna, P.; Pregnolato, M.; Invernizzi, A.G.; Mellerio, G. On the reaction between $3 H$-1,2-dithiolo[3,4-b]pyridine-3-thione and primary alkyl and arylalkylamines. J. Heterocycl. Chem., 1993, 30, 1079-1084.

[371] Goda, F.E.; Abdel-Aziz, A.A.M.; Attef, O.A. Synthesis, antimicrobial activity and conformational analysis of novel substituted pyridines: $\mathrm{BF}_{3}$-promoted reaction of hydrazine with 2-alkoxy pyridines. Bioorg. Med. Chem., 2004, $12,1845-1852$.

[372] Zhuravel', I.O.; Kovalenko, S.M.; Ivachtchenko, A.V.; Balakin, K.V.; Kazmirchuk, V.V. Synthesis and antimicrobial activity of 5-hydroxymethyl- 8methyl-2-( $N$-arylimino)-pyrano[2,3-c]pyridine-3-( $N$-aryl)-carboxamides. Bioorg. Med. Chem. Lett., 2005, 15, 5483-5487.

[373] Srivastava, B.K.; Solanki, M.; Mishra, B.; Soni, R.; Jayadev, S.; Valani, D.; Jain, M.; Patel, P.R. Synthesis and antibacterial activity of 4,5,6,7tetrahydro-thieno[3,2-c]pyridine quinolones. Bioorg. Med. Chem. Lett., 2007, 17, 1924-1929.
[374] Poreba, K.; Opolski, A.; Wietrzyk, J. Synthesis and antiproliferative activity in vitro of new 3 -substituted aminopyrazolo[3,4-b]pyridines. Acta Poloniae Pharm., 2002, 59, 215-222.

[375] Basnet, A.; Thapa, P.; Karki, R.; Choi, H.; Choi, J.H.; Yun, M.; Jeong, B.-S ; Jahng, Y.; Na, Y.; Cho, W.-J.; Kwon, Y.; Lee, C.-S.; Lee, E.-S. 2,6Dithienyl-4-furyl pyridines: synthesis, topoisomerase I and II inhibition, cytotoxicity, structure-activity relationship, and docking study. Bioorg. Med. Chem. Lett., 2010, 20, 42-47.

[376] Kim, H.J.; Jung, M.-H.; Kim, H.; El-Gamal, M.I.; Sim, T.B.; Lee, S.H.; Hong, J.H.; Hah, J.-M.; Cho, J.-H.; Choi, J. H.; Yoo, K.H.; Oh, C.-H. Synthesis and antiproliferative activity of pyrrolo[3,2- $b]$ pyridine derivatives against melanoma. Bioorg. Med. Chem. Lett., 2010, 20, 413-417.

[377] Gudmundsson, K.S.; Johns, B.A. Imidazo[1,2-a]pyridines with potent activity against herpes viruses. Bioorg. Med. Chem. Lett., 2007, 17, 2735-2739.

[378] Johns, B.A.; Gudmundsson, K.S.; Allen, S.H. Pyrazolo[1,5-a]pyridine antiherpetics: Effects of the $\mathrm{C} 3$ substituent on antiviral activity. Bioorg. Med Chem. Lett., 2007, 17, 2858-2862.

[379] Bringmann, G.; Reichert, Y.; Kane, V.V. The total synthesis of streptonigrin and related antitumor antibiotic natural products. Tetrahedron., 2004, 60 , 3539-3574.

[380] Drabu, S.; Kumar, N. Synthesis and biological screening of substituted 2 aminocyano pyridines. Asian J. Chem., 2007, 19, 4957-4959.

[381] Drabu, S.; Archna; Singh, S.; Munirajam, S.; Kumar, N. Synthesis and antiinflammatory activity of some 2 -amino pyridines. Indian J. Heterocycl. Chem., 2007, 16, 411-412.

[382] Elassar, A.Z.A. Synthesis and antimicrobial activity of new polyfunctionally substituted pyridines and their fused derivatives. Indian J. Chem. B., 2004, 43, 1314-1319.

[383] Gothwal, P.; Malhotra, G.; Srivastava, Y.K. Microwave assisted synthesis and antimicrobial activities of some 2-amino-4-aryl-3-cyano-6-(4' hydroxyphenyl)-pyridines. E-J. Chem., 2011, 8, 119-122.

[384] Kidwai, M.; Thakur, R.; Saxena, S. A facile synthesis of substituted pyridines and pyrazolo[3,4-b]pyridines. J. Heterocycl. Chem., 2005, 42, 11811183.

[385] Kidwai, M.; Thakur, R.; Rastogi, S. Ecofriendly synthesis of substituted pyridine and pyrido[2,3-d]pyrimidine derivatives. Russ. Chem. Bull., 2005, $54,1523-1526$.

[386] Dediu, O.G.; Yehia, N.A.M.; Oeser, T.; Polborn, K.; Mueller, T.J.J. Coupling-isomerization-enamine addition-cyclocondensation sequences: a multicomponent approach to substituted and annelated pyridines. Eur. J. Org. Chem., 2005, 1834-1848.

[387] Feng, H.; Li, Y.; Van der Eycken, E.V.; Peng, Y.; Song, G. Synthesis of polysubstituted pyridines under combined microwave and ultrasound irradiation: $\mathrm{K}_{2} \mathrm{CO}_{3}$-promoted tandem addition/cyclization/hydrogen shift process Tetrahedron Lett., 2012, 53, 1160-1162.

[388] Geng, L.-J.; Feng, G.-L.; Yu, J.-G.; Zhang, H.-L. Multicomponent reaction for the synthesis of pyridine derivatives based on triphenylamine. J. Chem. Res., 2011, 74-76.

[389] Geng, L.-J.; Feng, G.-L.; Yu, J.-G.; Zhang, H.-L.; Zhang, Y.-M. Multicomponent reaction for synthesis of 2-(indol-3-yl)pyridine derivatives under microwave irradiation. Synth. Commun., 2011, 41, 3448-3454.

[390] Geng, L.-J.; Feng, G.-L.; Yu, J.-G. Synthesis of 2-(1H-indol-3-yl)pyridine derivatives through multi-component reaction. J. Chem. Res., 2010, 565-567.

[391] Miao, C.-B.; Wang, Y.-H.; Dong, C.-P.; Yang, H.-T.; Meng, Q.; Sun, X.-Q. A mild and convenient one-pot synthesis of 4,6-diaryl-3-aminoisoxazolo[3,4b]pyridines. Heterocycles., 2013, 87, 2599-2605.

[392] Radha, K.; Thapa, P.; Yoo, H.Y.; Kadayat, T.M.; Park, P.-H.; Na, Y.; Lee, E.; Jeon, K.-H.; Cho, W.-J.; Choi, H.; Kwonc, Y.; Lee, E.-S. Dihydroxylated 2,4,6-triphenyl pyridines: Synthesis, topoisomerase I and II inhibitory activity, cytotoxicity, and structure-activity relationship study. Eur. J. Med. Chem., 2012, 49, 219-228.

[393] Mulwad, V.V.; Satwe, D.S. Synthesis and antimicrobial screening of 2,4 diaryl-6-[2'H-[1']4'-hydroxy-2'-oxo-benzo-pyran-3'-y1]pyridines and 2,6 diaryl-4-[2'H-[1']-4'-hydroxy-2' -oxo-benzopyran-3'-y1]pyridines. Indian J. Chem. B., 2004, 43, 2727-2730.

[394] Katritzky, A.R.; Serdyuk, L.; Chassaing, C.; Toader, D.; Wang, X.J.; Forood, B.; Flatt, B.; Sun, C.C.; Vo, K. Syntheses of 2-alkylamino- and 2dialkylamino-4,6-diarylpyridines and 2,4,6-trisubstituted pyrimidines using solid-phase-bound chalcones. J. Comb. Chem., 2000, 2, 182-185.

[395] El-Enany, M.M.; El-Meligie, S.E.M.; Abdou, N.A.; El-Nassan, H.B. Synthesis of pyrazolo[3,4-b]pyridine and pyrido[2',3':3,4]pyrazolo[1,5a]pyrimidine derivatives. J. Chem. Res., 2010, 470-474.

[396] Zou, X.; Tu, S. J.; Shi, F.; Xu, J. N. An efficient synthesis of pyrazolo[3,4-b] pyridine derivatives under microwave irradiation. Arkivoc., 2006, ii, 130-135.

[397] Iaroshenko, V.O.; Mkrtchyan, S.; Volochnyuk, D.M.; Langer, P.; Sosnovskikh, V.Y.; Ostrovskyi, D.; Dudkin, S.; Kotljarov, A.V.; Miliutina, M.; Savych, I.; Tolmachev, A.A. 3-Formylchromones, acylpyruvates, and chalcone as valuable substrates for the syntheses of fused pyridines. Synthesis. 2010, 2749-2758.

[398] Wang, X.-S.; Zhang, M.-M.; Li, Q.; Yao, C.-S.; Tu, S.-J. Simple procedure for the synthesis of 5,7-diarylpyrido[2,3-d]pyrimidine derivatives catalyzed by KF-alumina. Synth. Commun., 2008, 38, 1896-1908.

[399] Trilleras, J.; De La Torre, P.; Pacheco, D.J.; Quiroga, J.; Nogueras, M. Cobo, J. Solvent-free microwave-assisted synthesis of substituted pyridines using $\mathrm{NH}_{4} \mathrm{OAc}$ as nitrogen source. Lett. Org. Chem., 2011, 8, 652-655. 
[400] Bazgir, A.; Khanaposhtani, M.M.; Soorki, A.A. One-pot synthesis and antibacterial activities of pyrazolo[ $\left[4^{\prime}, 3^{\prime}: 5,6\right]$ pyrido[2,3- $d$ ]pyrimidine-dione derivatives. Bioorg. Med. Chem. Lett., 2008, 18, 5800-5803.

[401] Habib, N.; Soliman, R.; El-Tombary, A.; El-Hawash, S.; Shaaban, O. Synthesis of thiazolo[4,5-d]pyrimidine derivatives as potential antimicrobial agents. Arch. Pharm. Res., 2007, 30, 1511-1520.

[402] Johar, M. Manning, T; Kunimoto, D.Y; Kumar, R. Synthesis and in vitro anti-mycobacterial activity of 5-substituted pyrimidine nucleosides. Bioorg. Med. Chem., 2005, 13, 6663-6671.

[403] Li, J.; Zhao, Y.F.; Zhao, X.L.; Yuan, X.Y.; Gong, P. Synthesis and antitumor activities of novel pyrazolo[1,5-a]pyrimidines. Arch. Pharm., 2006, 339, 593-597.

[404] Shallal, H.M.; Russu, W.A. Discovery, synthesis, and investigation of the antitumor activity of novel piperazinylpyrimidine derivatives. Eur. J. Med. Chem., 2011, 46, 2043-2057.

[405] Cosimelli, B.; Greco, G.; Ehlardo, M.; Novellino, E.; Da Settimo, F.; Taliani, S.; La Motta, C.; Bellandi, M.; Tuccinardi, T.; Martinelli, A.; Ciampi, O.; Trincavelli, M.L.; Martini, C. Derivatives of 4-amino-6-hydroxy-2mercaptopyrimidine as novel, potent, and selective $\mathrm{A}_{3}$ adenosine receptor antagonists. J. Med. Chem., 2008, 51, 1764-1770.

[406] Bhat, K.I.; Kumar, A.; Thara, P.V.; Kumar, P. Synthesis, characterization and biological activity studies of some substituted pyrimidine derivatives. Indian J. Heterocycl. Chem., 2014, 23, 271-276.

[407] Yejella, R.P.; Atla, S.R. A study of anti-inflammatory and analgesic activity of new 2,4,6-trisubstituted pyrimidines. Chem. Pharm. Bull., 2011, 59, 10791082 .

[408] Patel, N.B.; Patel, H.R. Design and synthesis of new imidazolinone derivatives as potential antifungal agents. J. Heterocycl. Chem., 2011, 48, 373-380.

[409] Shi, Y.; Liu, Q.; Tang, J. Synthesis, characterization, and optical properties of 2-amino-4-aryl-6-(9,9'-spirobifluoren-2-yl)pyrimidines. Monatsh. Chem., 2011, 142, 907-916.

[410] Umaa, K.; Ramanathan, M.; Krishnakumar, K.; Kannan, K. Elucidation and evaluation of substituted pyrimidines. Asian J. Chem., 2009, 21, 6674-6678.

[411] Rashinkar, G.S.; Pore, S.B.; Mote, K.B.; Salunkhe, R.S. An efficient synthesis of novel 2-amino-4-aryl-6-ferrocenyl pyrimidines. Indian J. Chem. B., 2009, 48, 606-610

[412] Cabaj, J.; Doskocz, J.; Soloducho, J.; Chyla, A. Convenient synthesis and physicochemical profile of new derivatives of pyrimidine. Heterocycles., 2006, 68, 137-149.

[413] Desai, N.J.; Desai, K.R. Synthesis and antibacterial activity of chalcone and 2-amino pyrimidine and their related compound. Asian J. Chem., 2003, 15, 650-654.

[414] Patel, N.B.; Patel, H.R. Characterization and pharmacological evaluation of new pyridine analogs. Arabian J. Chem., 2012, 5, 81-91.

[415] Patel, N.B.; Patel, H.R. Synthesis and pharmacological studies of 5-ethyl pyridin-2-ethanol analogs derivatives. Arkivoc., 2009, xii, 302-321.

[416] Pathak, V.; Maurya, H.K.; Sharma, S.; Srivastava, K.K.; Gupta, A. Synthesis and biological evaluation of substituted 4,6-diarylpyrimidines and 3,5diphenyl-4,5-dihydro-1H-pyrazoles as anti-tubercular agentes. Bioorg. Med. Chem. Lett., 2014, 24, 2892-2896.

[417] Panda, S.S.; Chowdary, P.V.R. Synthesis of novel indolyl-pyrimidine antiinflammatory, antioxidant and antibacterial agents. Indian J. Pharm. Sci., 2008, 70, 208-215.

[418] Amin, K.M.; Awadalla, F.M.; Eissa, A.A.M.; Abou-Seri, S.M.; Hassan, G.S.: Design, synthesis and vasorelaxant evaluation of novel coumarin-pyrimidine hybrids. Bioorg. Med. Chem., 2011, 19, 6087-6097.
[419] Anand, N. Singh, P · Sharma, A · Tiwari, S · Singh, V * Singh, D.K.; Srivastava, K.K.; Singh, B.N.; Tripathi, R.P. Synthesis and evaluation of small libraries of triazolylmethoxy chalcones, flavanones and 2-aminopyrimidines as inhibitors of mycobacterial FAS-II and PknG. Bioorg. Med. Chem., 2012, 20 , 5150-5163.

[420] Katritzky, A.R.; Soloducho, J.; Belyakov, S. Bis-4-halophenyl-pyrimidines and -1,2,4,5-tetrazines. Arkivoc., 2000, $i, 37-42$

[421] Waheed, A.; Alorainy, M.S.; Alghasham, A.A.; Khan, S.A.; Raza, M. Synthesis of a new series of substituted pyrimidines and its evaluation for antibacterial and antinociceptive effects. Int. J. Health Sci., 2008, 2, 39-48.

[422] Nagaraj, A.; Reddy, C.S. Synthesis and biological study of novel bischalcones, bis-thiazines and bis-pyrimidines. J. Iranian Chem. Soc., 2008, 5 , 262-267.

[423] Thore, S.N. Synthesis of some 3,5-bis-1,4-dihydro-4-phenyl 2,6-dimethyl pyridino-2'-amino-6'-phenyl pyrimidines. Asian J. Chem., 2007, 19, 4429-4432.

[424] Parveen, H.; Hayat, F.; Mukhtar, S.; Salahuddin, A.; Khan, A.; Islam, F.; Azam, A. Synthesis, characterization and biological evaluation of novel 2,4,6-trisubstituted bis-pyrimidine derivatives. Eur. J. Med. Chem., 2011, 46 , 4669-4675.

[425] Rajanarendar, E.; Ramakrishna, S.; Murthy, K.R. Synthesis of novel isoxazolyl bis-thiazolo[3,2-a]pyrimidines. Chin. Chem. Lett., 2012, 23, 899-902.

[426] Trivedi, A.R.; Dodiya, D.K.; Ravat, N.R.; Shah, V.H. Synthesis and biological evaluation of some new pyrimidines via a novel chalcone series. Arkivoc, 2008, xi, 131-141.

[427] Majeed, J.; Shaharyar, M. Synthesis and in vivo diuretic activity of some novel pyrimidine derivatives. J. Enzyme Inhib. Med. Chem., 2011, 26, 819-826.

[428] Kumar, D.B.A.; Prakash, G.K.; Kumaraswamy, M.N.; Nandeshwarappa, B.P.; Sherigara, B.S.; Mahadevan, K.M. Microwave assisted facile synthesis of amino pyrimidines bearing benzofuran and investigation of their antimicrobial activity. Indian J. Chem. B., 2006, 45, 1699-1703.

[429] Rostom, S.A.F.; Badr, M.H.; Abd El Razik, H.A.; Ashour, H.M.A.; Wahab, A.E.A. Synthesis of some pyrazolines and pyrimidines derived from polymethoxy chalcones as anticancer and antimicrobial agents. Arch Pharm.Chem. Life Sci., 2011, 344, 572-587.

[430] Gaikwad, S.S.; Suryawanshi, V.S.; Lohar, K.S.; Jadhav, D.V.; Shinde, N.D. Synthesis and biological activity of some 3,4-dihydro-4-(4-substituted aryl)6-(naptho[2,1-b]furan-2-yl pyrimidine-2(1H)-one derivatives. E-J. Chem. 2012, 9, 175-180.

[431] Sangaraiah, N.; Murugan, S.; Poovan, S.; Raja, R.; Alagusundaram, P Ramakrishnan, V.; Vellasamy, S. Facile water promoted synthesis of 1,2,3triazolyl dihydropyrimidine-2-thione hybrids - Highly potent antibacteria agents. Eur. J. Med. Chem., 2012, 58, 464-469.

[432] Desenko, S.M.; Gladkov, E.S.; Shishkina, S.V.; Shishkin, O.V.; Komykhov, S.A.; Orlov, V.D.; Meier, H. Synthesis and tautomerization of 6,7-dihydro(1,2,3)-triazolo[1,5-a]pyrimidines. J. Heterocycl. Chem., 2006, 43, 1563 1567

[433] Sayed, A.Z.; Aboul-Fetouh, M.S.; Nassar, H.S. Synthesis, biological activity and dyeing performance of some novel azo disperse dyes incorporating pyrazolo[1,5-a]pyrimidines for dyeing of polyester fabrics. J. Mol. Struct., 2012, 1010, 146-151.

[434] Dawane, B.S.; Konda, S.G.; Zangade, S.B.: Design, synthesis, and characterization of some novel pyrazolo[1,5-a]pyrimidines as potent antimicrobial agents. J. Heterocycl. Chem., 2010, 47, 1250-1254.

[435] Rajanarendar, E.; Raju, S.; Reddy, M.N.; Murthy, K.R. An elegant one-pot synthesis of isoxazolo[2,3-a]pyrimidines. Indian J. Chem. B., 2010, 49, $1422-1427$. 